Historic, Archive Document

Do not assume content reflects current scientific knowledge, policies, or practices. 



\section{ULLATHORNE'S SEEDS FOR GARDEN AND FIELD}

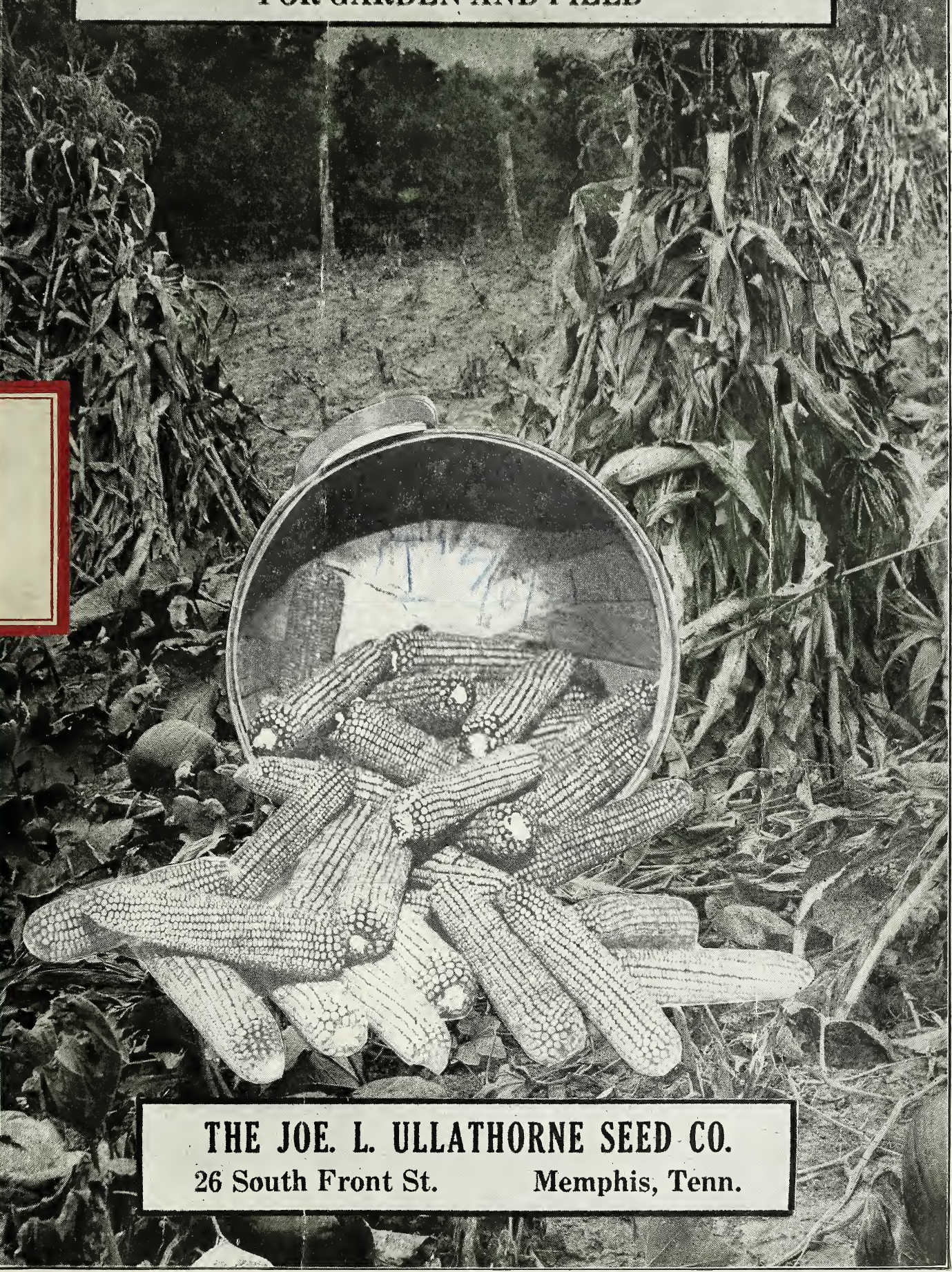




\section{ULLATHORNE'S SEEDS FOR GARDEN AND FIELD}

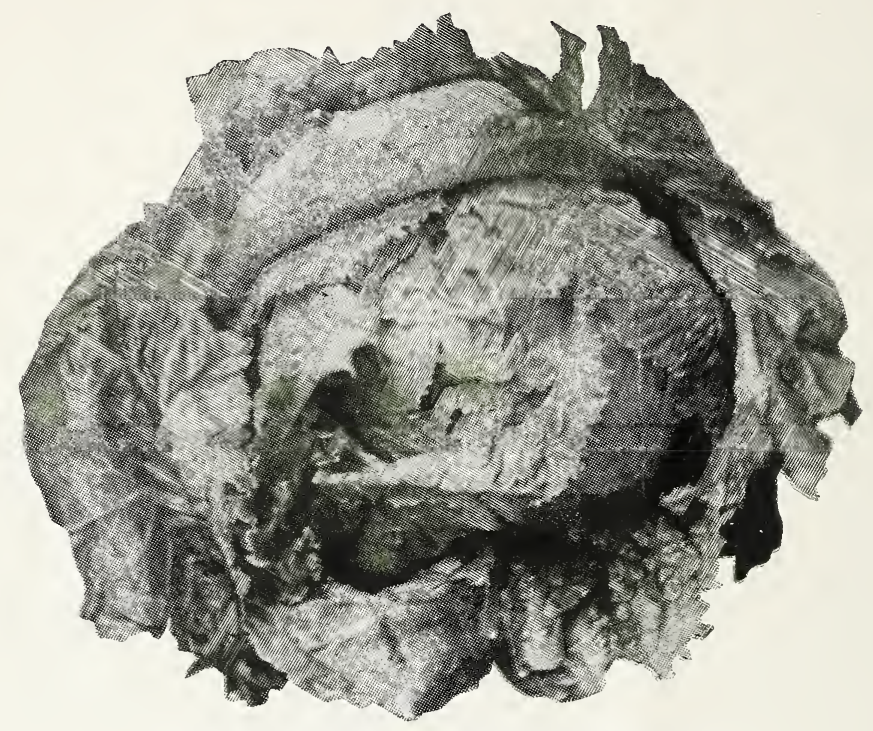

NEW YORK WONDERFUL LETTUCE

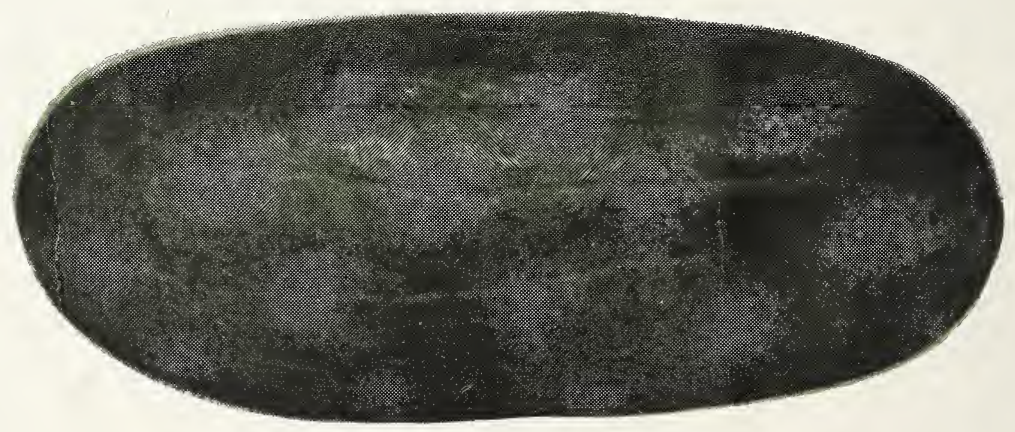

IRISH GREY WATERMELON

\section{The Joe. L. Ullathorne Seed Co. 26 S. Front St., MEMPIS, TENN.}




\section{Beans}

THE CENTAL SYSTEM

Beans and Peas are sold by the pound. A pint of each is about one pound. Buy by the Cental System. It is exact, accurate and fair to all, and permits quicker. and more accurate Parcel Post rating.

\section{Dwarf Wax and Green Pod Beans}

Prices on All Beans Listed Will Be Found at the Bottom of the Page.

Planting Directions-1 lb. to $100 \mathrm{ft}$. of row; 1 acre requires $60 \mathrm{lbs}$.

All varieties of beans should be planted when danger of frost is past. For a continuous supply plant every two weeks to about August 1st. Select a warm, sunny location and a fairly rich, sandy soil, if possible. Plant in rows 18 to 30 inches apart, 2 inches deep and 4 to 6 inch between the plants in the row. Cultivate or hoe in dry weather, but avoid working among the beans when plants are wet, as this induces rust.

RED VALENTINE-Very popular green-podded snap bean, specially adapted for the South. Ready

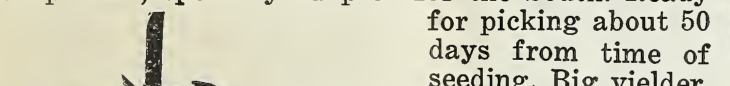
days from time of full, round, meaty

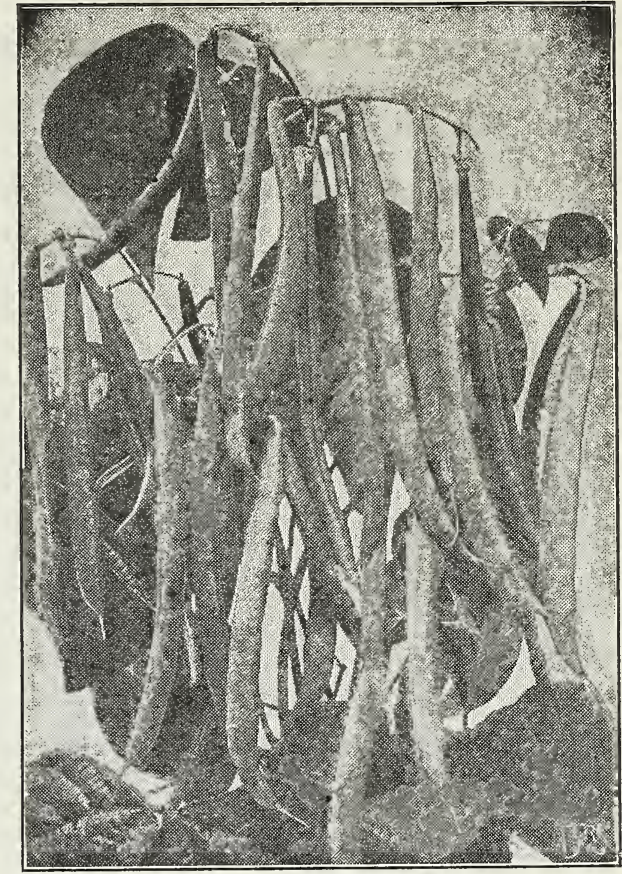

RED VAIENTINE pods of unusual tenderness.

BURPEE'S STRINGLESS GREENPOD-A splendid round podded green variety, excellent for both home and market gardeners.

BLACK VALENTINE-An early variety used largely for shipping both in the North and South; very prolific and hardy. Pods are flat.

FULL MEASURE-A fine stringless early variety of high quality. The pods are of medium green color, straight, 6 inches long, very fleshy, round.

IMPROVED GOLDEN WAX-Vines medium sized, vigorous and hardy; pods broad, flat of a golden yellow color. This variety is an improvement over the old Golden Wax. The plants are very resistant to rust.

DAVIS KIDNEY WAX-One of the best varieties in existence. Planted extensively by market gardeners for its ready sale on any market. Fine for cooking as a dry bean.

Prices on all Dwarf Wax and Green Pod-Pkt., 10c; 1/4 lb., 20c; $1 \mathrm{lb} ., 40 \mathrm{c}$; postpaid.

\section{POLE BEANS}

Planting Directions-1 lb. to 100 hills; 1 acre requires about $30 \mathrm{lbs}$.

Poles should be 6 to 8 feet high and placed in rows north and south. Rows should be about $31 / 2$ feet apart each way and the seed planted in a circle 6 inches from the pole and 6 to 8 seeds to each pole. Place poles firmly in the ground and have them all slanting toward the north.

SOUTHERN CORNFIELD-A very hardy and productive cornfield bean. The vines are of good climbing habit with small deep green leaves.

KENTUCKY WONDER-Pods are green, about 10 inches long, nearly round, fleshly, stringless and of fine flavor. Early and very prolific. Seed is long, oval, of yellowish color.

ST. LOUIS PERFECTION WHITE-An early maturing, green podded, white seeded pole sort desirable for snaps and unsurpassed in its class as green shell beans. The vines are vigorous and very productive. The pods are round, very long, often eight to nine inches, irregular in shape and quite stringless.

KENTUCKY WONDER Prices on all Pole Beans-Pkt., 10c; 1/4 lb., 20c; $1 \mathrm{lb} ., 40 \mathrm{c}$; postpaid. 


\section{Lima Beans}

Lima Beans are the best for boiling, baking or canningtasty and delicious, far superior to the ordinary white bean of commerce. Suitable for all sections, North and South Yield continuously from early summer to frost.

We earnestly recommend a much more extensive use of Lima Beans as a table food. They are not used as largely as they should be, because it is not generally known that in a dry state they can be used in the same manner as the common beans, and keep equally well. Lima Beans are much richer and more dolicate in flavor than ordinary beans, and are unexcelled for either boiling, baking or canning. They are also very desirable served as green beans, either alone or eaten with sweet corn in the form of succotash.

\section{POLE LIMA VARIETIES}

Planting Directions-1 lb. to $100 \mathrm{ft}$. row; 1 acres requires about $35 \mathrm{lbs}$.

Pole Lima Beans should be planted in rich soil, and a sunny location. Have the poles lean towards the north. Four feet between the rows and 3 feet between the poles in the row. Plant 6 to 8 beans around each pole. Thin out and leave the five strongest plants. If poles are scarce put posts 10 feet apart, stretch single wires or netting along

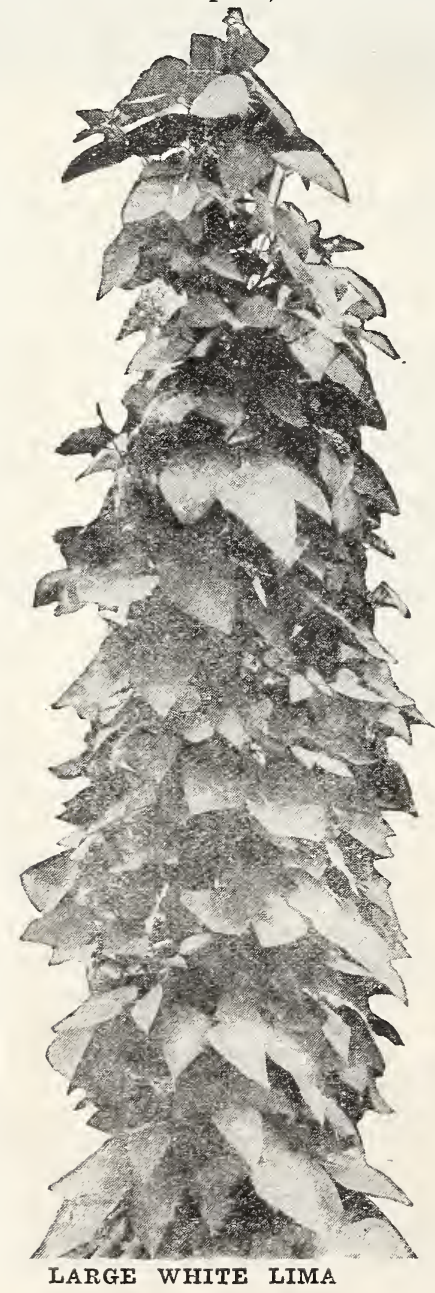
and plant the beans 8 to 10 inches apart.

LARGE WHITE LIMA-A well-known pole variety, vines tall, vigorous and slender. Seed very large, ovoid, flat, white with slight greenish tinge. The pods grow in clusters. This is a general favorite wherever it may be cultivated; the germ of the Lima Bean is very delicate, and sometimes the first planting is destroyed by cold and wet weather.

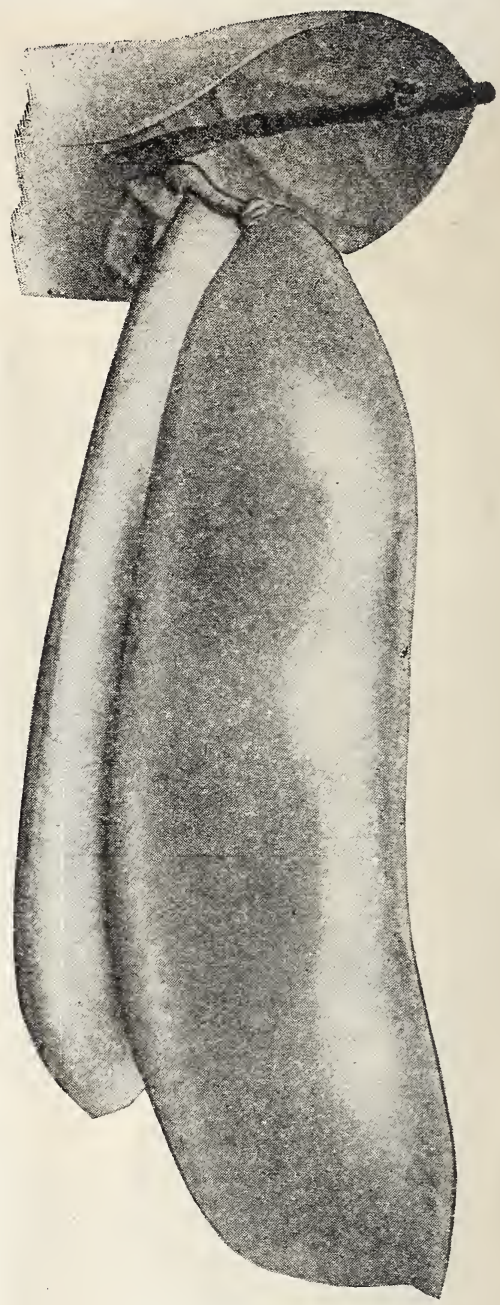

HENDERSON'S BUSH
CAROLINA or SMALL WHITE SIEVA-(The "Butter Bean" of the South) The vines are slender, with rather small, shiny, dark-green leaves. Thick pods; large flavory beans; matures quickly, very productive, bears throughout the season.

\section{BUSH LIMA VIARIETIES}

Planting Directions-1 lb. to 100 feet of row; 1 acre requires 50 pounds.

Plant in drills two to three feet apart, dropping beans three to four inches apart and covering one and one-half to two inches deep. If planted in hills, make the hills two to three feet apart one way and two to two and one-half feet the other and plant four to six beans in a hill. Hoe often but only when the leaves are dry.

HENDERSON'S BUSH-One of the most valuable of the bush varieties owing to its extreme earliness, hardiness and productiveness. The plants are without runners but continue to grow and set until stopped by frost.

FORDHOOK BUSH-This is the only variety with a stiffy. erect bush form habit, branching freely but branches of upright growth. The pods are proauced in large clusters, medium green, about 5 inches long and each containing: 4 to 5 large beans of the finest qua'ity.

Prices on all Pole and Bush Lima Beans-Pkt., 10c; 1/4 lb., 20c; 1 lb., 50c, postpaid. 


\section{Beets}

\section{TABLE VARIETIES}

Planting Directions $-1 \mathrm{oz}$. will sow about $100 \mathrm{ft}$. row; 1 acre requires $7 \mathrm{lbs}$.

Beets require a deep, rich, sandy loam and can be sown as early as the ground can be worked in the spring. Sow in rows 12 to 18 inches apart. Sow $3 / 4$ to 1 inch deep. Use the young tops for greens. CROSBY'S IMROVED EXTRA EARLY EGYPTIAN BEETAn improvement on Extra Early Egyptian being as early, but of more desirable shape, color and quality. It is very sweet and tender; a most valuable sort for early market, as it is ready before any other Beet of equal quality.

CRIMSON GLOBE-Second Early Main Crop-This is a splendid sort; is extensively planted for second early and main crop purposes; is medium size, about 10 inches around, globe shape, uniform, without rootlets and perfectly smooth. Foliage is small, rich, purple-bronze color. Flesh is rich blood red, sweet, tender and never stringy.

DETROIT DARK RED-We believe this is the best beet for the market and home garden, and on account of its uniformly deep rich color the most desirable for canning. The tops are small and upright in growth. The leaves are dark green, shaded with red. The roots are medium sized, globular or nearly round, very smooth and oi dark red color. The flesh is deep vermilion red, zoned with a lighter shade of the same color.

EXTRA EARLY ECLIPSE-Remarkable for its very rapid growth, the perfection of its
form--which is globular-for its beautiful crimson flesh, and for its dwarf foliage. Roots are bright ulossy red.

SWISS CHARD or SILVER BEET-Grown exclusively for the foliage, which cooked makes most delicious green

Prices on all Beets-Pkt., 5c; 1 oz., $15 \mathrm{c} ; 1 / 4$ 1b., $40 \mathrm{c} ; 1$ lb., $\$ 1.00$, postpaid. By freight
or express; $10 \mathrm{lbs}, 75 \mathrm{c} 1 \mathrm{~b}$.

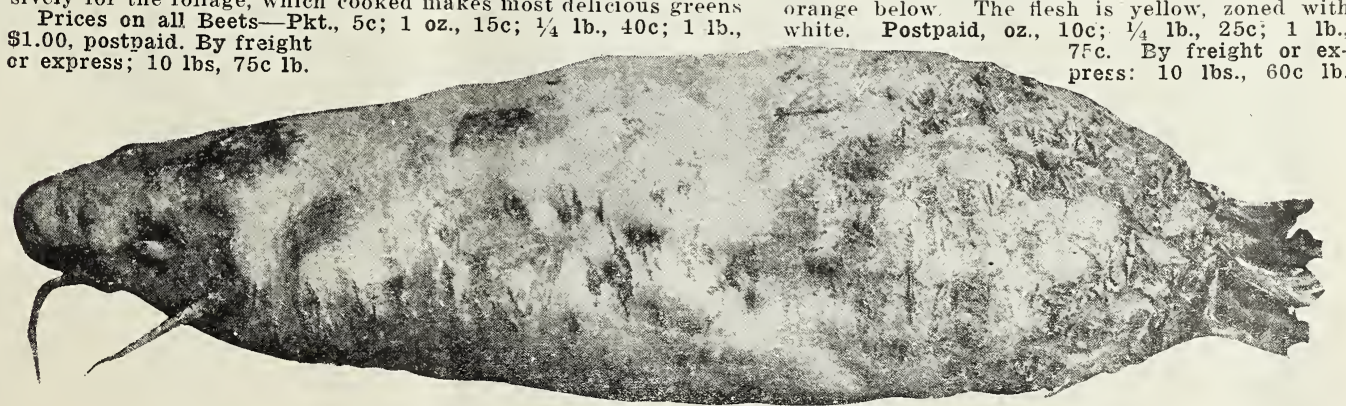

Planting Directions -1 oz. to $100 \mathrm{ft}$. row; 6 to $8 \mathrm{lbs}$. per acre.

Select a rich, sandy loam if possible. Sow in rows 2 feet apart and thin to 6 to 8 inches in the row. When beets are formed discontinue cultivation.

Sugar Beets are an important crop, both for the production of sugar and for stock feeding. The beets are ready to harvest when the lower leaves begin to take on a yellow tinge and droop. Beet tops are fine feed for cows, sheep and other live stock. A combination of beet pulp and Alfalfa is one of the best-cattle feeds. When small, sugar beets are fine for table use.

KLEIN'S WANZLEBEN-A white variety containing a large percentage of sugar and probably the variety most planted. Often yields from 12 to 16 tons per acre. Postpaid, oz., $10 \mathrm{c} ; 1 / 4$ lb., 25c; 1 lb., 75c. By freight or express: 10 lbs., 60c.

\section{MANGEL BEETS}

Planting Directions-1 oz. to $100 \mathrm{ft}$. row; 1 acre requires $5 \mathrm{lbs}$.

Mangels thrive best in a rich, deep loam. Sow when the ground is warm and not too early in spring. Mangels grow partly above ground and may be damaged by frost. Corn planting time is about $r_{1}$. it for sowing mangels. sow $1 \mathrm{n}$ rows $3 \mathrm{ft}$. apart, $1 \frac{1}{2} \mathrm{in}$. deep and leave the plants stand $8 \mathrm{in}$. in t.e row. Cultivate often to retain moisture.

MAMMOTH LONG RED-The roots are very large, straight and well formed. The flesh is white, tinged with rose. This variety, under ireful culture is enormously productive; very fine for stock feeding. A great favorite with $f$ rmers and dairymen. Postprid, oz., 10c; 1/4 1). $25 \mathrm{c}$; 1b., $75 \mathrm{c}$; by freight or express, $10 \mathrm{lbs}$. $16 \mathrm{c}$ per $\mathrm{lb}$.

GOLDEN TANKARD-The tops are comparatively small, with leaf stalks and veins "istinctly tinged with yellow. The neck is small. The roots are large, with botton usually larger than the top; light gray above ground: deep orange below The flesh is yellow, zoned with white, Postpaid, oz., 10c; $1 / 4$ lb., 25c; 1 lb., $75 \mathrm{c}$ By freight or ex-

SUGAR BEETS 


\section{Brussels Sprouts}

Culture-Sow in May, in the same manner as Cauliflower, and transplant in July, 1 foot apart in rows 11/2 feet apart. Brussels Sprouts is the very best winter vegetable that can be grown. It is as hardy as the common Curled Greens. When cooked through, such sprouts melt in the mouth like the tenderest Cauliflower, and are equally as good.

PARIS HALF DWARF-Pkt., 10c; 1 oz., 40c;

1/4 lb., $\$ 1.25 ; 1$ lb., $\$ 4.50$, postpaid.

\section{Broccoli}

The heads resemble somewhat a coarse cauliflower and the culture is the same in all essentials as for that vegetable.

EARLY LARGE WHITE FRENCH-This is considered the best sort for most sections. Pkt. 10c; 1 oz., 75c; $1 / 4$ lb., 40c; 1 lb., \$9.00.

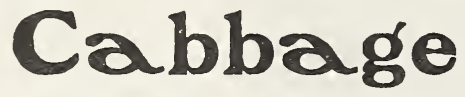

Planting Directions-1 oz. for about 4,000 plants.

Enrich the soil with plenty of manure and spade or plow deep. Good drainage is necessary. Sow inside in boxes or under glass 6 weeks before planting out. Plant in rows $2 \mathrm{ft}$. apart and 18 inches apart in the row. For late cabbage, sow outside in seedbeds in May and transplant in rows $21 / 2 \mathrm{ft}$. apart and $2 \mathrm{ft}$. between plants in the row.

\section{First Early Varieties}

EARLY JERSEY WAKEFIELD_This wellknown standard variety is the earliest of the pointed head cabbages. Heads are very hard, solid and pointed. This variety is a sure header. Pkt., 10c; 1 oz., 35c; 1/4 lb., 90c; 1 lb., \$3.00, postpaid.

CHARLESTON WAKEFIELD-On the order of Jersey Wakefield, but not quite so pointed; heads are much larger, solid and maturing about 10 days later. Pkt., 10c; 1 oz., 35c; 1/4 lb., 90c; 1 lb., $\$ 3.00$, postpaid.

COPENHAGEN MARKET-Considered the earliest of the round headed varieties. Can be planted both for early and late cabbage,

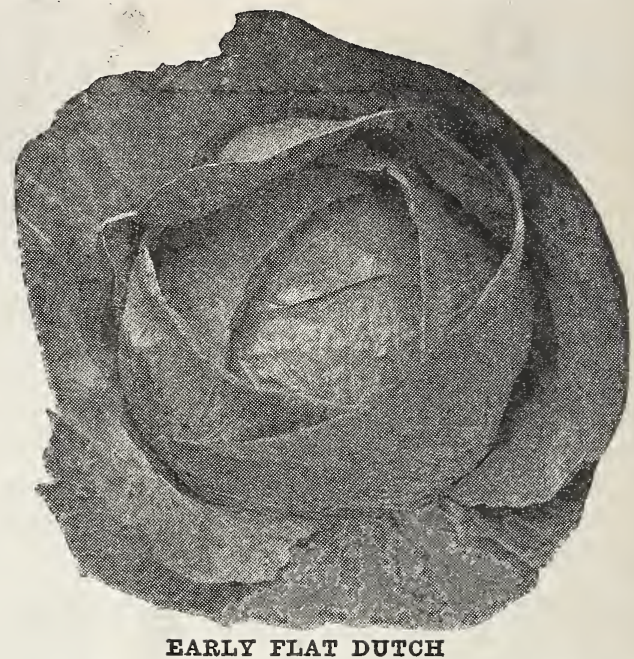

forming very large, solid, round heads on a short stem and has few outer leaves. Quality fine and sweet. Grown by market gardeners not only for early cabbage, but for medium and late crop also. Pkt., 10c; 1 oz., 40c; 1/4 lb., $\$ 1.25$; 1 lb., \$3.75, postpaid.

\section{Second Early Varieties}

EARLY SPRING-Probably the earliest of flat-headed varieties. A profitable cabbage to grow as it heads early, has a short stem forming a round somewhat flat head quickly. Quality excellent, owing to its fine flavor. Pkt., 10c; 1 oz., 40c; $1 / 4$ lb., \$1.10; 1 lb., \$3.25, postpaid.

EARLY SUMMER - A fine second early flatheaded variety. Plants are rapid, strong growing and short stemmed. Forms solid, flattened, round and generally large heads. Heads weighing 10 to $12 \mathrm{lbs}$. are not uncommon. Pkt., 10c; 1 oz., 35c; 1/4 lb., 90c; 1 lb., $\$ 3.00$, postpaid.

EARLY FLAT DUTCH-The heads are large and solid and mature very early-just after the select Jersey Wakefield. In every respect it is a Cabbage worthy of cultivation. Pkt., 10c; 1 oz., 35c; 1/4 lb., 90c; 1 lb., \$3; postpaid.

HENDERSON'S EARLY SUCCESSION-A wonderful cabbage for solidity, productive-

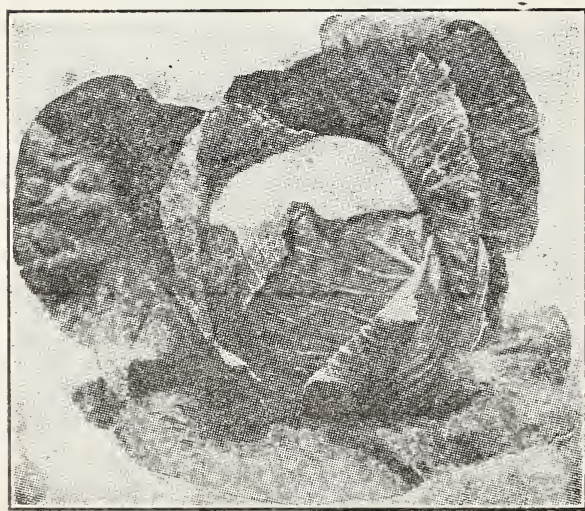
ness and fine, large heads. Pkt., 10c; 1 oz., 35c; $1 / 4$ lb., 90c; 1 lb., $\$ 3.00$, postpaid.

EARLY SHORT STEM DRUMHEAD-It is ready for market 2 or 3 weeks earlier than the late Drumheads, forms large, solid, rounded heads. Pkt., 10c; $1 \mathrm{oz}$., 35c; 1/4 lb., 90c; 1 lb., \$3.00, postpaid.

\section{Fall or Late Varieties}

PREMIUM LATE FLAT DUTCH-An exceedingly large variety, very hardy and a sure header. Heads are flat but deep, solid and a good keeper. Pkt., 10c; 1 oz., 35c; $1 / 4$ lb., 90c; $\$ 3.00$ postpaid.

LARGE LATE DRUMHEAD-Grows a very large, solid head, often reaching a weight heavier than other varieties. There is little outer foliage, the leaves all folding in closely about the head. A fine winter variety. Pkt., 10c; 1 oz., 35c; 1/4 lb., 90c; 1 lb., $\$ 3.00$ postpaid. 


\section{Corn Salad}

This is a small, quick growing salad for late fall, winter and spring use. The leaves are used as a substitute for lettuce and spinach. Pkt., 10c; 1 oz., 20c; 1/4 lb., 80c; 1 lb., $\$ 2.75$, postpaid.

\section{Collards}

Sow the seeds thickly in drills, in rich ground, transplanting when about four inches high; or sow in drills where the plants are to remain and when well started thin to two or three feet apart in the row. In the south, seed may be sown from January to May and from August to October.

GEORGIA, SOUTHERN or CREOLE-This is the white or green stemmed variety, growing two to three feet high and forming a large ,loose, open head or cluster of leaves with a rather long stem. A frost, if not too severe, will improve rather than injure the quality of the leaves. Pkt., 5c; oz., 10c; 2 oz., 15c; $1 / 4$ lb., 25c; lb., 80c.

\section{Cauliflower}

Planting Directions-1 oz. for 2,000 plants.

For early crop, sow seed in hotbed or in boxes about 6 weeks before time to plant out. Transplant early in spring in rows 3 feet apart and 18 inches in the row. Plants should be cultivated often to be kept growing continuously. When heads begin to form the leaves should be tied together over the head to keep out the light and produce fine white heads.

EARLY SNOWBALL-The earliest maturing strain of the true type of Snowball Cauliflower. A good forcing variety, and can also be used as a late crop for winter.

EXTRA EARLY DWARF ERFURT-This variety is early dwarf and a sure header, although not quite as early as the Snowball.

DANISH DRYWEATHER-This variety is especially valuable in sections subject to long

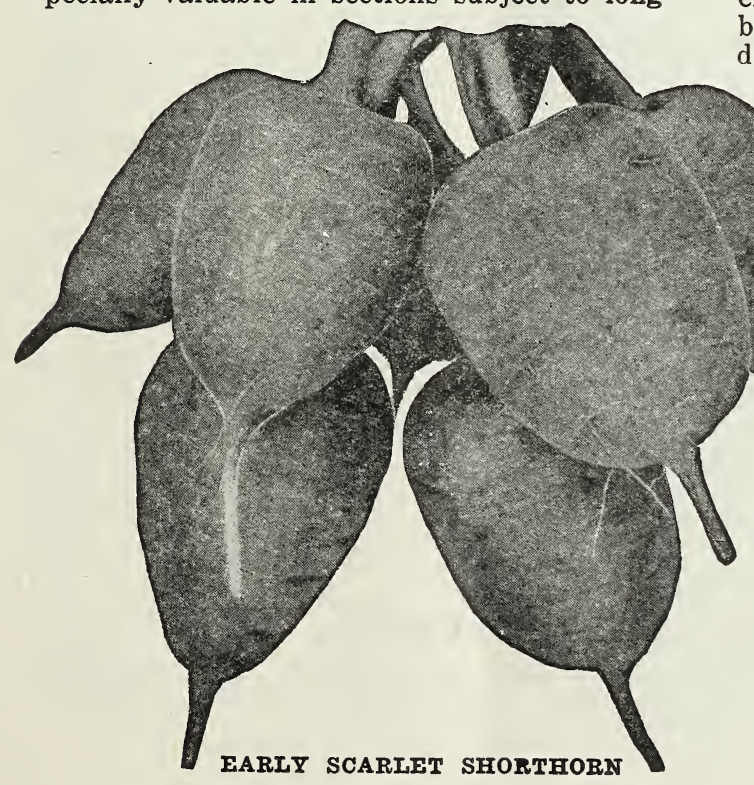

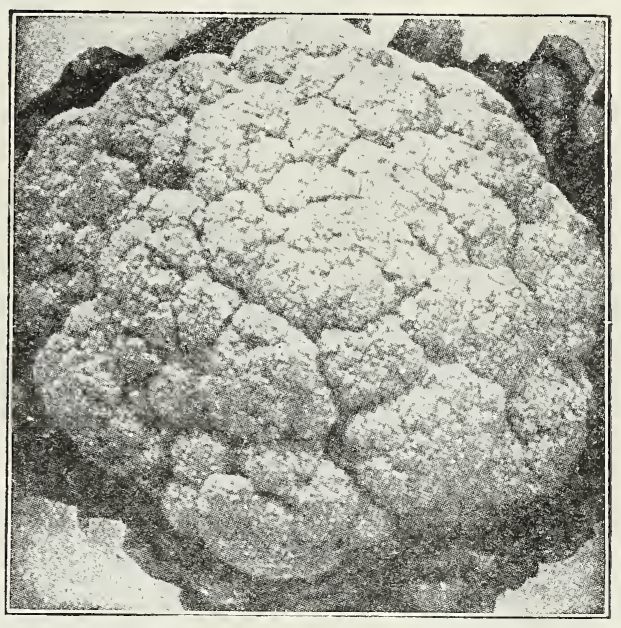

EARIY SNOWBALL

dry seasons, as it will do well and produce fine heads in lack of moisture.

Prices on all Cauliflower-Pkt., 25c; $1 / 4$ oz., 85 c; $1 / 2$ oz., $\$ 1.50 ; 1$ oz., $\$ 3.00$.

\section{Carrots}

Planting Directions- $1 / 4$ oz. to $100 \mathrm{ft}$. row; $1 \frac{1}{2}$ to $3 \mathrm{lbs}$. per acre.

A sandy, rich loam, and deeply cultivated is the better soil for carrots. For home gardens sow in rows 16 inches apart and thin to 6 inches in the row. For field culture 18 to 24 inches between rows. Cover 1 inch and thin to 6 inches between plants.

DANVERS - A half long orange carrot, grown largely on account of its great productiveness and adaptability to all classes of soil. The mature roots are of medium length, six to eight inches long, tapering uniformly to a blunt point. The flesh is a deep orange, tender and of good quality.

IMPROVED LONG ORANGEMost popular of the long sorts. Deep orange color, about 3 inches thick at the top and about 12 inches long, tapering to a point. Very productive, but requires a deep soil; of good quality when young and fine for stock feeding when matured.

EARLY SCARLET SHORT HORN This variety is very short, almost round, fine for early use in home garden. Deep orange in color. Prices on all above varieties-Pkt., 5c; 1 oz., 15c; $1 / 4$ lb., 30c; 1 lb., 1 lb., 90c; postpaid.

LARGE WHITE BELGIAN CARROTProduces large roots four inches in diameter at the top and 10 inches in length. It has a white skin and flesh. These carrots are grown for feeding stock during winter; they keep stock in fine condition. Pkts., 5c and 10c; oz., 10c; $1 / 4$ lb., 25e; $1 / 2 \mathrm{lb}$., 40c; $1 \mathrm{lb}$., 75e, postpaid. 


\section{Celery}

Planting Directions-1 oz. for 3,000 plants; 4 oz. required for 1 acre.

Celery does well in muck land but can be grown in any good-preferably moist-garden soil. Sow in rich soil, in boxes inside or in frames under glass. When plants are 2 inches high, transplant again in boxes or cold frames 2 inches each way. Seeds germinate slow, in about 20 days.

Dig trenches $4 \mathrm{ft}$. apart and 6 in. deep, set the plants 6 to 8 inches apart in the trench. When plants are full grown fill in the trench for blanching.

GOLDEN SELF-BLANCHING (American Grown)--Our strain seed is unexcelled and will produce tender, crisp celery. Postpaid, pkt., $10 \mathrm{c} ; 1 / 2$ oz., 30c; oz., 60c; $1 / 4 \mathrm{lb}$., $\$ 1.00 ; 1 \mathrm{lb} ., \$ 3.00$.

WHITE PLUME-An attractive quick growing early variety, wellknown for the short time necessary in blanching. Suitable for the home garden and market on account of earliness. Postpaid, pkt., 5c; oz., 30c; $1 / 4$ lb., $\$ 1.00 ; 1 b ., \$ 3.50$.

\section{CELERIC, OR TURNIP-ROOTED CELERY}

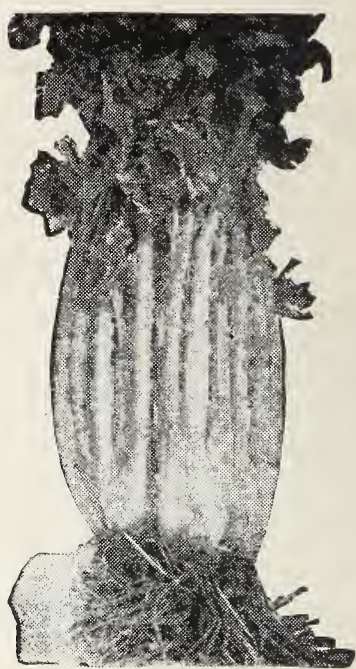

Golden Self Blanching

Culture for Root Celery-Sow the seed at the same season and give the same treatment as Celery. Transplant the young plants to moist, rich soil in rows two feet apart and six inches in the rows. Pkt., 10c; 1 oz., 30c; $1 / 4$ lb., $85 \mathrm{c}$; postpaid.

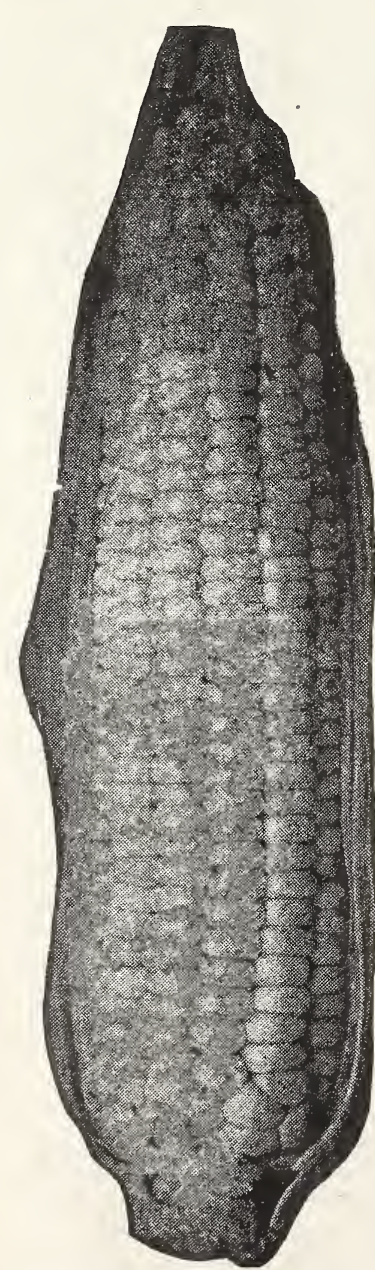

STOWELL'S EVERGREEN

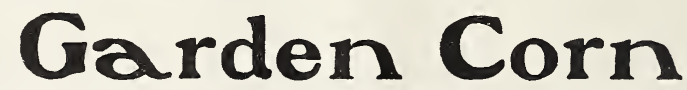

Planting Directions-1 lb to 100 hills; 1 acre requires 12 to $15 \mathrm{lbs}$. Select an exposed sunny location away from trees and hedges. Spread well-rotted manure liberally over the ground and plow or spade this under deep. Plant when danger of frost.is past. Plant in rows 3 to 4 feet apart. Drop 4 to 5 kernels every $2 \frac{1}{2}$ feet. Cover 1 inch. These distances enable cultivation both ways. For early varieties plant $2 \frac{1}{2}$ feet between the rows, dropping 2 kernels every 18 inches. Plant every two weeks for a succession until the middle of July. Keep the weeds out. Cultivate or hoe often as this helps to keep the moisture in the ground. It is important to pick Sweet Corn at the right time. When the skin of the grain breaks at a slight puncture that is the time to pick.

EXTRA EARLY ADAMS-Same size, type and style as Early Adams Hardiest and earliest corn. It is not a Sugar Corn, but is grown for early use. Ears short, kernels very white. Like Early Adams it is hardy and can be planted early.

STOWELL'S EVERGREEN-Perhaps the most popular variety for main crop and general planting on a large scale. It grows to a good height; cars are very large, well filled to the tips. The sweet kernels are pure white, affording a ready sale. Ears are about 8 to 9 inches long, 16 to 18 rowed.

EARLY ADAMS-An excellent early field variety and often used for table, particularly in the South. The ears are about eight inches long, twelve to fourteen rowed.

GOLDEN BANTAM-Finest home garden variety, and in a class by itself for quality. Superior in many ways to other Sweet Corn. Very early, sweet and tender. Cobs are well filled with deep cream colored kernels. We cannot recommend this variety too highly for the home garden.

COUNTRY GENTLEMAN-Is a late main crop variety, which should find a place with every grower for home or market. The arrs, which are seven to nine inches long are borne on stalks six to seven feet high.

HOWLING MOB-This variety originated at Toledo, Ohio, and its queer but appropriate name has reference to the loud and clamorous demand for the corn when brought to market. The stalks are usually about 5 feet in height and nroduce two splendid ears to a stalk early in the season.

EARLY SURPRISE-It is not a sugar corn, but ranks almost equal. A favorite for early market larger than the early Adams corn and onlr a few days later: ears about 8 inches. always well filled to the tip: grains pure white, tender and makes the very best roasting ears.

PRICE ON ALL CORN-Pkt., $10 \mathrm{c}$; $1 / 4 \mathrm{lb}$., $20 \mathrm{c}$; $1 \mathrm{lb} ., 35 \mathrm{c}$; postpaid.

\section{Pop Corn}

WHITE RICE-A popular variety with "Cracker Jack" men. The kernels are pointed and resemble rice. It matures later than other varieties but yields heavily and "pops" fine.

GOLDEN QUEEN-Yellow grain and a good "popper."

POP CORN PRICES-Pkt., 10c; 1/4 lb., 15c; $1 \mathrm{lb} ., 35 \mathrm{c}$; postpaid. 


\section{Cucumbers}

Planting Directions-1 oz. for 60 hills; 3 lbs. for an acre in hills.

Cucumbers require a rich loam. It is well to plow or dig under wellrotted manure and a small amount of lime. The lime will help the plants to resist fungous diseases. For early use sow in berry boxes or on overturned pieces of sod and transplant when all danger of frost is past. Sow in hills 4 to 6 feet apart each way, three-quarters of an inch deep, leaving six plants to a hill. Sow a little thick as the bugs will get some of the plants.

DAVIS PERFECT-A well-known variety for both home garden and market use. Very prolific; handsomely shaped, perfectly straight, of dark green color, and about 12 inches long. Used for slicing. Pkt., 5c; oz., 15c; $1 / 4$ lb., 40c; 1 lb., \$1.25; postpaid.

IMPROVED LONG GREEN-A standard variety, used for slicing while young. With age it turns to a rich golden yellow, when it can be used for sweet pickles. Pkt., 5c; oz., 15c; $1 / 4$ lb., 40c; 1 lb., $\$ 1.40$; postpaid.

EVERGREEN WHITE SPINE-A fine strain, bearing blue green fruit, often 10 to $12 \mathrm{in}$. in length; smooth, round and of quality. Especially recommended for hotbed culture. The seed we offer has been taken from fruit selected for its ideal form, uniformity in size, shape and color and general appearance. A very satisfactory variety in every way. Pkt., 5c; oz., 15c; $1 / 4$ lb., 35c; 1 lb., \$1.25; postpaid.

CHICAGO PICKLING-This variety is perhaps the most popular of the pickling varieties. It originated in the vicinity of Chicago, and has become well-known throughout the country. Very prolific and a heavy cropper. Color very dark green. Pkt., 5c; oz., $15 \mathrm{c} ; 1 / 4$ lb., 35c; 1 lb., $\$ 1.25$; postpaid.

GHERKIN-Grown exclusively for pickles; fruits small, oval and covered with spines; color light green. Pkt., 10c; oz., $25 c$; $1 / 4$ lb., 60c; 1 lb., $\$ 2.00$, postpaid.

\section{Kohlrabi}

Sow in June or July, in rows, thin to 12 inches.

Bulbs grow above ground, are stripped and cooked like turnips, but much sweeter.

EARLY WHITE VIENNALarge, quick growing, with greenish-white skin and tender white flesh. Pkt., 10 c; 1 oz., 20c; $1 / 4$ lb., 75c; 1 lb., $\$ 2.50$; postpaid.

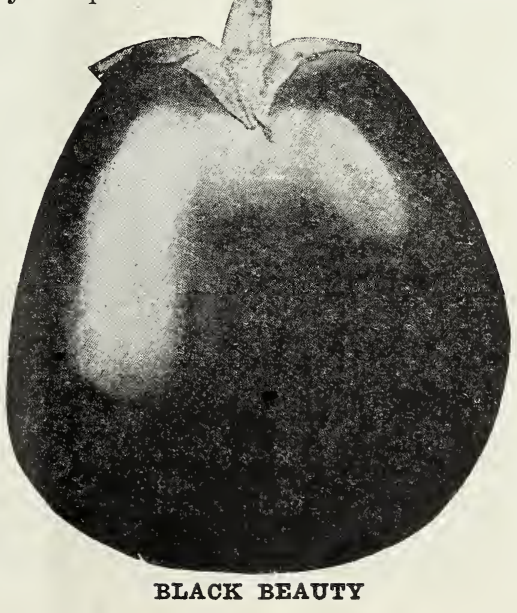

WHITE SPINE CUCUMBER

\section{Egg Plant}

Planting Directions-1 oz. for 2,000 plants.

Egg Plants are tropical plants and should not be planted out until all danger of frost is past. Sow early in boxes or under glass, preferably in small pots and transplant to open ground in rows $3 \frac{1 / 2}{2}$ to 4 feet apart. The plants may stand $2 \frac{1}{2}$ feet apart in the row. Select a warm, sunny location and plant in loose soil with little moisture. Cultivate often.

NEW YORK PURPLE SPINELESS-The plants are of low, stockly, branching growth and free from spines. It is early and produces an abundance of large purple fruits noted for their fine quality. Pkt., 10c; oz., 50 c; $1 / 4$ lb., $\$ 1.60 ; 1$ lb., $\$ 6.00$; postpaid.

BLACK BEAUTY-Ten days to two weeks earlier than the New York Improved Purple, fruits a little bit longer in shape and slightly darker. It is entirely free from spines around the corolla, of dark rich purplishblack color; very attractive. Pkt., 10c; oz., 60 ; $1 / 4$ lb., $\$ 1.75 ; 1$ lb., $\$ 6.50$; postpaid.

\section{Endive}

Planting Directions- $1 / 4$ oz. to 100 ft. of row; $4 \mathrm{lbs}$ to one acre.

Endive is grown in the same way as lettuce, but requires a longer time to develop. It takes about 50 days to grow a crop. Sow early in May in rows 15 in. apart and thin to $1 \mathrm{ft}$. apart in row. Endive should be blanched by tying up the outer leaves like celery when the plants are full grown. Draw up the soil about the plants.

GREEN CURLED - Resembling a tuft of moss, and one of the best salads. Foliage finely cut; crisp, tender and fine flavor. Valuable salad plant for fall and winter use.

Pkt., 5c; oz., 15c; 1/4 lb., 45c; 1 lb., $\$ 1.50$; postpaid, 


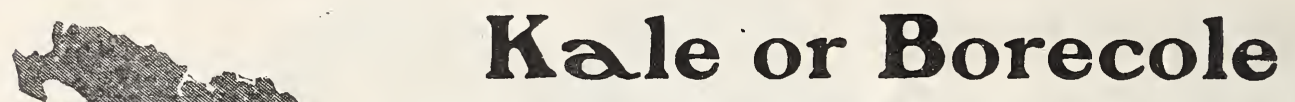

This is extensively grown, especially in the south during the fall, winter and spring. The leaves are used principally for greens. A favorite way is to cook them with bacon. The leaves are also used for garnishing.

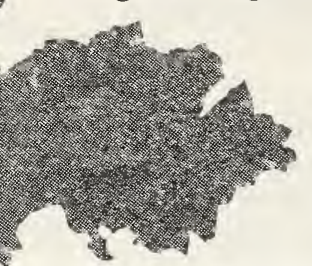

Where climate permits seed may be sown any time from August to October, broadcast or preferably in drills eighteen inches apart so that the plants when small may be cultivated. The quality is improved rather than injured by frosts if not too heavy.

TALL GREEN CURLED SCOTCH-The plant of

this variety grows to three or four feet high, bearing long, plume-like, light green leaves which are deeply cut, also finely curled at edges. Pkt., 5c; oz., 15c; 2 oz., 25c; $1 / 4$ lb., 40c; 1 lb., \$1.50; postpaid.

DWARF CURLED SCOTCH-A finely curled, spreading, low growing variety, very hardy and much used for greens. This sort, sometimes called Norfolk, is grown extensively in the south for shipment and is planted largely for the home garden. The leaves are long and attractive bright green. This sort is often used for garnishing. Pkt., 5c; oz., $15 \mathrm{c}$; $1 / 4 \mathrm{lb} ., 40 \mathrm{c} ; 1 \mathrm{lb} ., \$ 1.25$.

\section{Lettuce}

Planting Directions-1 oz. to $75 \mathrm{ft}$. row; 4 to $5 \mathrm{lbs}$. per acre.

Lettuce requires a mellow, moist and rich soil for best results. For early crop sow in hotbed or boxes inside. Outdoor culture can be started as soon as the ground can be worked in spring. Sow in rows $1 \frac{3 / 4}{\mathrm{ft} \text {. apart }}$ and thin to 3 inches between the plants in the row. Sow every 10 days. Water frequently. Head lettuce should stand 8 inches apart in the row.

BIG BOSTON - A very popular variety with market gardeners. Foliage a very light green with slightly ruffled edges; heads large and compact, making them very good for shipping purposes. Pkt., 10c; oz., $15 \mathrm{c} ; 1 / 4$ lb., 40c; $1 \mathrm{lb} ., \$ 1.25$; postpaid.

HANSON-One of the most desirable later summer lettuces. The plant is compact and forms a large, cabbage-like head which remains in condition longer than most heading sorts. Pkt., 10c; 1 oz., $15 \mathrm{c}$; $\mathrm{r} / 4$ lb., $40 \mathrm{c}$; 1 lb., $\$ 1.25$, postpaid.

WONDERFUL NEW YORK-This splendid mammoth heading and long-keeping variety has been grown to weigh 6 pounds to the head; frequently weighs 2 to $3 \mathrm{lbs}$. Heart is solid, of light green color, very sweet, tender and crisp. Long standing, perfect heads may be cut from the same bed for many weeks. Pkt., 10c; oz., 25c; $1 / 4$ Ib., 75c; 1 lb., $\$ 2.50$, postpaid.

PRIZEHEAD-Very popular, large, loose heading sort. Leaves finely crumpled and fringed, outer ones, shaded brown, very crisn. sweet and tender, splendid for home garden. Pkt., 5c; oz., $15 \mathrm{c}$; $1 / 41 \mathrm{~b} ., 35 \mathrm{c} ; 1$ 1b., $\$ 1.10$, postpaid.

MAY KING-A very early heading variety. This is among the nest of heading sorts. The outer leaves are green, just tinged with brown: they fold close, permitting close planting in frames-tender yellow heart. Pkt., 10c; oz., 15c; $1 / 4$ lb., $45 \mathrm{c}$; 1 lb., $\$ 1.50$.

\section{COS LETTUCE}

Considered by many the highest type of lettuce; has distinct upright habit, very crisp and sweet. Needs transplanting.

PARIS WHITE COS-Grows to large size. Self- closing. Pkt., 5c; 0z., 15c; $1 / 4$ lb., 35c; 1 lb., $\$ 1.25$, postpaid.

\section{Leek}

Planting Directions-1-3 oz. to $100 \mathrm{ft}$. row; 4 lbs. to 1 acre.

Similar requirements as for Onions. Sow early in April in rows $1 \mathrm{ft}$. apart covering 1 inch. Transplant or thin to 6 inches apart in row. When transplanting set the plants deep so that the bottom will be blanched. Draw the earth up about the plants from time to time.

An onion-like plant, but does not produce a large bulb like the common onion. It is milder than onions and the long branched stalks and green tops are fine for flavoring soups, stews, etc., the strong odor disappearing in cooking. Easily raised from seed.

LONDON FLAG-Similar in type to American Flag; perhaps a trifle larger, but later. Pkt., 5c; oz., 25c; $1 / 4$ lb., 75 c; 1 lb., $\$ 2.50$; postpaid.

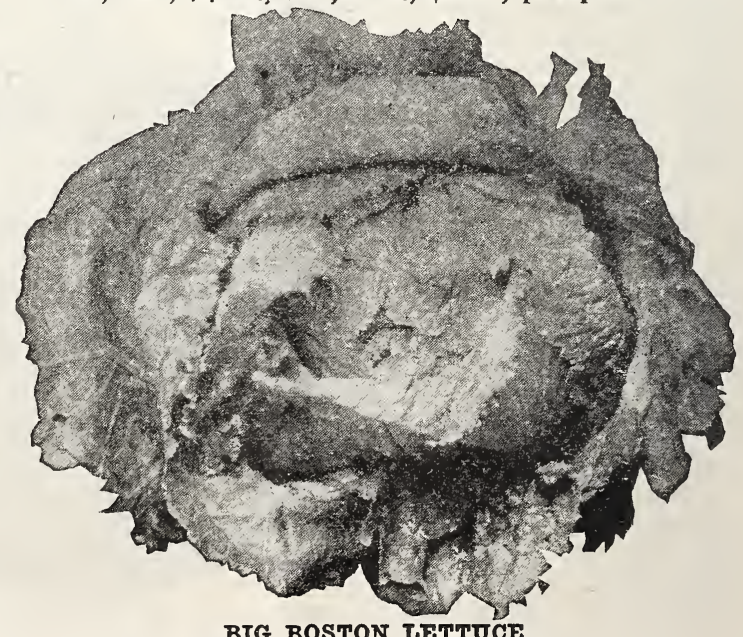

BIG BOSTON IETTUCE 


\section{Muskmelon}

Planting Directions -1 oz. to 100 hills; 2 to 3 lbs. per acre.

Muskmelons require a warm, sunny location. Sow in a rich, sandy loam in hills 4 to $6 \mathrm{ft}$. apart. About 10 seeds to a hill and thinning later leaving the 5 strongest. Cover the seeds 1 inch. To assist in ripening the fruit remove any leaves which may prevent the sun from reaching the melons.

ROCKY FORD-A really famous variety, known throughout the country for its exceptionally good qualities. Melons are netted and ribbed, solid green flesh and very sweet. Our seed is of selected stock. Pkt., 5c; 1 oz., 15c; 1/4 lb., 50c; 1 lb., $\$ 1.50$; postpaid.

POLLOCK SALMON No. 25-New variety of fine quality and extensively planted by home gardeners. In size it is equal to Rocky Ford. Flesh very thick, salmon color; excellent shipper. Pkt., 10c; oz., 20c; 1/4 lb., 45c; 1 lb., $\$ 1.50$, postpaid.

BANANA-Shaped somewhat as name indicates; grows about $2 \frac{1}{2} \mathrm{ft}$. long; flesh deep salmon colored and of only fair quality. Pkt., 5c; 1 oz., 25c; 2 oz., 40c; 1/4 lb., 65c; 1 lb., $\$ 2.25$; postpaid.

BALTIMORE OR ACME-A fine early, oblong, green-fleshed variety of good size; noticeably ribbed and heavily netted. Pkt., 5c; 1 oz., 20c; $1 / 4$ lb., 50c; 1 lb., $\$ 1.75$; postpaid.

PROLIFIC NETTED NUTMEG-This splendid melon is one of the very best varieties for either home use or the market. It has a very small seed cavity, deep green flesh, uniform shape, average about 5 inces. Pkt., 5c; 1 oz., 20c; 2 oz., 35c; 1/4 lb., 50c; 1 lb., \$1.75; postpaid.

HONEY DEW-The new melon. Average size 6 inces in diameter and 7 to 8 in length. Weight averages 8 to 10 pounds: The skin is smooth and the rind though thin is very tough. Will keep until Christmas. Creamy yellow when ripe. A good shipper. Pkt., 10c; 1 oz., 20c; 1/4 lb., 75c; 1 lb., $\$ 2.50$.

\section{Watermelon}

Planting Directions-4 oz. to 100 hills; 4 lbs. per acre.

Watermelons require a long season and do better where planted in a loose, sandy loam

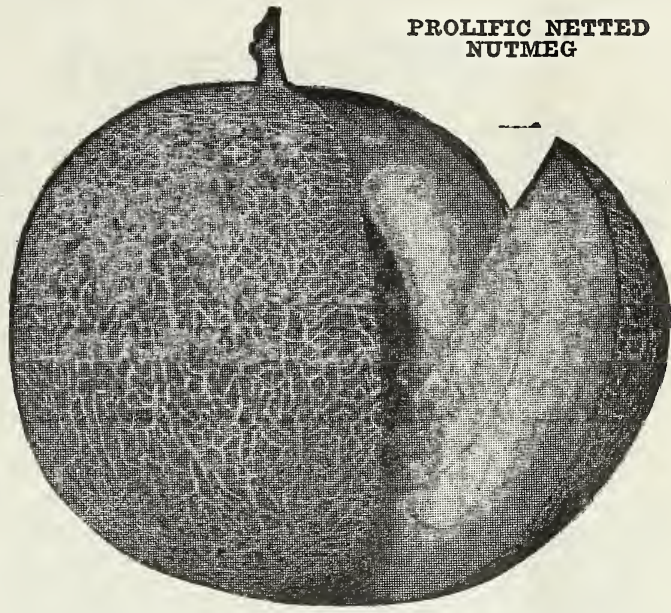

and in a sunny exposure. It is advisable to mix some well-rotted manure in each hill. The hills should be 8 feet apart each way. Place a shovel full or two of rich, loose soil on each hill and plant 10 seeds in each. When the plants are up thin out and leave the five strongest. Fertilize often with liquid manure and remove any leaves shading the melons.

TOM WATSON-There's delicious sweetness in every bite, for its eating is as splendid as its shipping quality. Flesh rich red, crisp and tenderly melting. It is 24 in. long, 12 in. through, dark mottled green rind, thin but strong-flesh can be eaten almost to the skin. A great money maker in all markets. Pkt., 5c; oz., 15c; $1 / 4$ lb., 35c; lb., $\$ 1.00$; postpaid.

KLECKLEY'S SWEET-This very popular melon is one of the best for nearby markets. Fruits are medium size, oblong, dark green color, very thin rind. Flesh bright scarlet with solid heart, crisp, sugary and melting; free from stringiness. Pkt., 5c; 1 oz., 15c; 2 oz., 25c; $1 / 4$ lb., 40c; 1 lb., $\$ 1.00$, postpaid.

HALBERT HONEY-Large, attractive oblong shape; rind dark green, flesh crimson; very sweet and tender. Pkt., 5c; 1 oz., 15c; 2 oz., 25c; $1 / 4$ lb., 40c; 1 lb., $\$ 1.00$; postpaid.

GEORGIA RATTLESNAKE-Large, oblong, striped; flesh red, of fine quality. Pkt., 5c; 1 oz., 15c; 2 oz., 25c; $1 / 4$ lb., 35c; 1 lb., $\$ 1.00$.

FLORIDA FAVORITE-Fruit long, dark green mottled and striped with a lighter shade. Rind thin but firm. Pkt., 5c; 1 oz., 15c; 2 oz., 25c; $1 / 4$ lb., 35c; 1 lb., $\$ 1.00$, postpaid.

IRISH GREY-This melon was introduced three years ago and bids fair to supplant Tom Watson in the markets throughout the country. It has a very thin rind, but extremely tough, and is of a light grey color which prevents sunburn. Its keeping qualities are excellent. The flesh is of delicious sweetness, rich red, crisp and tenderly melting. Pkt. 10c; oz., 20c; 1/4 lb., 75c; 1 lb., \$2.50; postpaid. 


\section{Mustard}

Planting Directions-1 oz. to $100 \mathrm{ft}$. row.

Mustard thrives best in a rich, quick, loose and naturally moist soil. For salad, sow in rows 1 foot apart with plants an inch or two apart in the row. For general purpose, that is when seed is required for pickles, pepper sauce, etc., sow in rows one and one-half feet apart and plants three to four inches apart in the row. Cover the seed about one-half inch. Sow ever ten days for succession.

SOUTHERN GIANT CURLED-The leaves are large,

light green with tinge of yellow, much crimped and frilied at edges. The plant is upright or slightly spreading in growth. Pkt., 5c; $1 \mathrm{oz} ., 15 \mathrm{c} ; 1 / 4 \mathrm{lb} ., 30 \mathrm{c}$; 1 lb., 75c; postpaid.

LARGE SMOOTH LEAVED-An excellent sort with very large, light green, plain or comparatively smooth leaves, borne well above the ground. Pkt., 5c; 1 oz., 15c; 1/4 lb., 30c; 1 lb., 75c; postpaid.

\section{Okra or Gumbo}

Planting Directions-1 oz. to $100 \mathrm{ft}$. row.

Requires a rich soil. Okra is a tropical plant and should be planted in rows $3 \mathrm{ft}$. apart and thin to 10 to 12 inches between plants in the row. The green pods are used in soups and stews and are very nourishing.

WHITE VELVET - Distinct in appearance; the large pods are perfectly round, smooth, an attractive velvety white, of superior flavor and tenderness. Plant dwarf, of compact, branching growth, very prolific. Pkt., 5c; oz., 10c; $1 / 4$ lb., 20c; 1 lb., 60c; postpaid.

I M P R O V E D early sort; pods short. Fine quality. Pkt., 5c; oz., 10c; $1 / 4$ lb., 20c; lb., $60 \mathrm{c}$; postpaid.

PERKINS MAMMOTH PODDED-Pkt., 5c; oz. 10c; $1 / 4$ lb., 20c; 1 lb., $60 \mathrm{c}$; postpaid.

TALL LONG GREEN Long, slender, pale green pods. Pkt., 5c; oz., 10c; 1/4 lb., 20c; 1 lb., 60c; postpaid.

EX T R A E R L Y DWARF - Of dwarf, stocky growth, very early and prolific. Pkt., 5c; oz., 10c; 1/4 1b., 20c; 1 lb., 60c; postpaid.

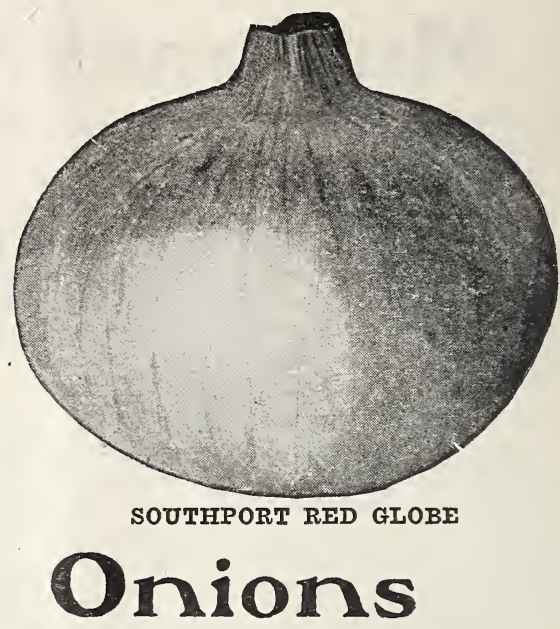

Planting Directions-1 oz. for $100 \mathrm{ft}$. row; 5 to $6 \mathrm{lbs}$. per acre.

Onions require a very rich soil. Spread wellrotted manure liberally over the ground in fall, plow or spade this under deep. Leave the ground lay rough during winter. The alternate thawing and freezing will help to pulverize the soil. In spring prepare seedbed smooth and level. Plant as early as possible in rows 1 foot apart and thin to $3-4$ inch between plants. Cultivate often and keep onions free from weeds.

LARGE RED WETHERSFIELD-The bulbs are large and are flattened yet quite thick. The skin is deep purplish red. The flesh is light purplish white, moderately fine grained, rather strong but of pleasant flavor. Pkt. $10 \mathrm{c} ; 1 \mathrm{oz} ., 20 \mathrm{c}$; $1 / 4$ lb., 65c; 1 lb., 2.25, postpaid SOUTHPORT RED GLOBE-Similar in good qualities to Southport Yellow Globe. Fine shipper, being used extensively through the South. is good yielder and matures early. Color is a rich, dark red; thin, glossy skin. Pkt., 10c; 1 oz., 20c; 1/4 lb., 75c; 1 lb., 2.50 .

YELLOW GLOBE DANVERS-A well known and standard variety; heavy cropper and excellent keeper; skin of light yellow, even color. Ripens early. Pkt., 10c; 1 oz., 20c; 1/a lb., 65c; 1 lb., $\$ 2.25$.

SOUTHPORT WHITE GLOBE-One of the best of the Globe varieties. Large in size, fine in quality, bringing a ready sale anywhere. Color a silvery white. Pkt., 10c; 1 oz., 20c: 1/4 1b., 75c; 1 lb., $\$ 2.50$.

\section{Onion Sets}

$1 \mathrm{ct}$. to $200 \mathrm{ft}$. of row; 10 to $12 \mathrm{bu}$. per acre. Plant the sets 4 inches apart in rows about $1 / 2$ inch deep and 1 foot between the rows, but do not corer the plants entirely. All varieties can be set out in the fall as well as in the spring

WHITE SILVER SKIN-1 lb., 40c; postpaid. RED WETHERSFIELD-1 lb., 35c; postpaid. YEI,LOW DANVERS-1 lb.. 35c. postpaid.

WHITE WHITE MULTIPLIERS-1 lb., 40c; postpaid. YELLOW POTATO-1 lb., 40c; postpaid.

Write for prices on large quantities as market varies. 


\section{Parsley}

Planting Directions-One ounce will sow $150 \mathrm{ft}$. of drill. Sow early in the spring in drills a foot apart. The seed germinates slowly, often 2 or 3 weeks will elapse before the plants will make their appearance. Often it fails entirely in dry weather. Thin to 6 or 8 inches and keep the soil loose:

DOUBLE or CURLED-Leaves crimped or curled; used principally as a garnish. Pkt., 5c; 1 oz., $15 \mathrm{c} ; 1 / 4 \mathrm{lb} ., 30 \mathrm{c} ; 1 \mathrm{lb} ., 80 \mathrm{c}$; postpaid.

PLAIN or SINGLE-Stronger in flavor than the curled varieties. Pkt., 5c; 1 oz., 15c; $1 / 4$ lb., 30c; $1 \mathrm{lb} ., 80 \mathrm{c}$; postpaid.

\section{CO RSEIO}

Planting Directions-A rich, sandy loam, deeply worked, is the best. Sow in spring, in drills 18 inches apart, covering lightly. When 2 inches high thin out to 4 to 6 inches apart. One ounce will sow 200 feet of drill. Five pounds to the acre.

HOLLOW CROWN or SUGAR-Roots long and smooth. The best either for table or stock-feeding use. Pkt., 5c; 1 oz., 10c; 1/4 lb., 25c; 1 lb., 85c; postpaid.

\section{1 eas}

Planting Directions-1 lb. to $125 \mathrm{ft}$. row; 1 acre requires about $100 \mathrm{lbs}$.

Peas are safe to sow as early as the ground can be worked. They do well in cool weather. Select a light, not too rich soil, or they will

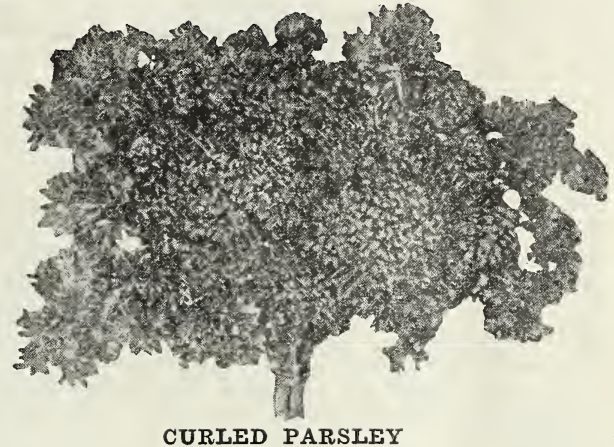

run to vine too much. Sow double rows, these to be 6 inches apart and $21 / 2$ to $3 \frac{3 / 4}{\mathrm{ft}}$. between the double rows, and drop the peas every 3 inches and covering $1 \frac{1}{2}$ inches. Like the flowering sweet peas the garden variety will produce better if 6-inch deep furrows are made, covering only 1 inch at the time of sowing and filling in the furrow when the plants are nicely started.

FIRST AND BEST-A popular first early variety; vines are very hardy, growing $2 \frac{1}{2}$ to 3 feet high, and producing from 5 to 7 medium sized peas in each pod. Quality good. Pkt., 10c; 1/4 lb., 20c; 1 lb., 35c; postpaid.

ALASKA-A well known pea among canners and truckers for early use. Fine for home gardens; height $2 \frac{1 / 2}{\text { feet; }}$ one of the earliest of the round varieties. Pods blunt at the ends. Peas green in color when ripe. A popular early variety. Pkt., 10c; $1 / 4$ lb., 20c; 1 lb., 35c; postpaid.

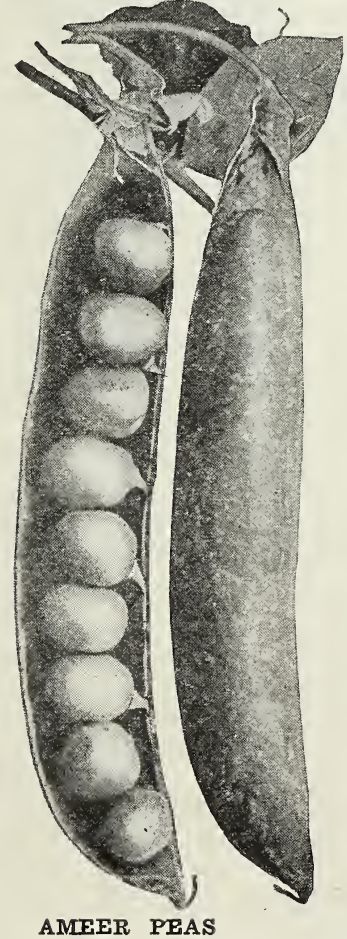

AMEER-A new and valuable strain of the popular Alaska Pea, the distinctive superiority being that it makes much larger pods and is more prolific. The vines grow 24 inches. Pkt., 10c; $1 / 4$ lb., 20c; 1 lb., 50c; postpaid.

ALDERMAN-The pods are very large, straight and dark green color. The vines are exceedingly vigorous and immensely prolific; of the best quality. Pkt., 10c; 1/4 lb., 20c; $1 \mathrm{lb} ., 50 \mathrm{c}$; postpaid.

TELEPHONE-A leader with market gardeners. Hardy and very productive. Pods often 4 to 5 inches long, well filled with a fine quality of peas; considered a main crop variety and one of the best for either home or market use. Height four feet. Pkt., 10c; 1/4 lb., 20c; $1 \mathrm{lb} ., 40 \mathrm{c}$; postpaid.

LARGE MARROWFAT-A tall, late variety and great yielder of ordinary quality. Pkt., 10c; 1/4 lb., 20c; 1 lb., 35c; postpaid.

\section{Evinn Dins}

Planting Directions-Plant April 15th to June in hills 8 to 10 feet apart, mixing well-rotted manure in each hill, 5 or 6 seeds in each hill and cultivate till vines get strong, when they should be thinned out, leaving 2 or 3 in each hill. When planted in corn, plant at the same time as the corn, in every fourth row, 10 to 12 feet apart in the rows. Do not grow near squashes or melons.

GREEN STRIPED CUSHAW-Pkt., 10c; 1 oz., 20c; 1/4 lb., 65c; $1 \mathrm{lb}$., $\$ 2.00$; postpaid.

TENNESSEE SWEET POTATO_Pkt., 10c; 1 oz., 15c; $1 / 4$ lb., 50c; $1 \mathrm{lb} ., \$ 1.50$; postpaid.

KENTUCKY FIELD-Pkt., 5c; 1 oz., 10c; 1/4 lb., 25c; 1 lb., 80c; postpaid. 


\section{Peppers}

Planting Directions-One ounce will produce about 1,000 plants. Sow in hotbed in March and transplant to the open ground as soon as the weather is warm and settled. Set in 3-foot rows about 2 feet apart. Cultivate well and keep free from weeds; hen manure worked into the soil when the plants are young will greatly increase the yield.

CHINESE GIANT-Plant dwarf, fruit of mammoth size, very broad but rather short. It is very late and a rather shy yielder. Popular on account of its large size and mild flavor. Pkt., 10c; 1/2 oz., $40 \mathrm{c} ; 1 \mathrm{oz}$., $60 \mathrm{c}$; $1 / 4$ lb., $\$ 2.00 ; 1$ lb., $\$ 6.50$, postpaid.

RUBY GIANT-This is a cross of Ruby King and Chinese Giant, which has made it a very attractive variety; it grows to a large size, of very handsome appearance, of a bright scarlet color, and is exceedingly mild. Pkt., 10c; 1 oz., 50c; 1/4 lb., $\$ 1.75 ; 1$ lb., $\$ 6.00$, postpaid.

LARGE BELL or BULL NOSE-Sometimes called Sweet Mountain. Plant vigorous, compact, very productive, ripening its fruit uniformly and early. Fruit large with thick flesh, usually hot. Pkt., 10c; 1 oz., 40c; $1 / 2$ lb., $\$ 1.25 ; 1$ lb., $\$ 4.50$; postpaid.

PERFECTION PIMENTO-The only canning pepper for making "pimento." Slips skin when heated. Big size. Thick meat. Meat three times thicker than Bell Peppers, and yields 50 per cent more edible product. Scarlet when ripe; yields until frost. Pkt., 10c; 1 oz., 60 c; $1 / 4$ lb., $\$ 2.00 ; 1$ lb., $\$ 6.00$; postpaid.

LONG RED CAYENNE-A long red variety, very hot, and is usually used for seasoning soups, etc. Pkt., 10c.

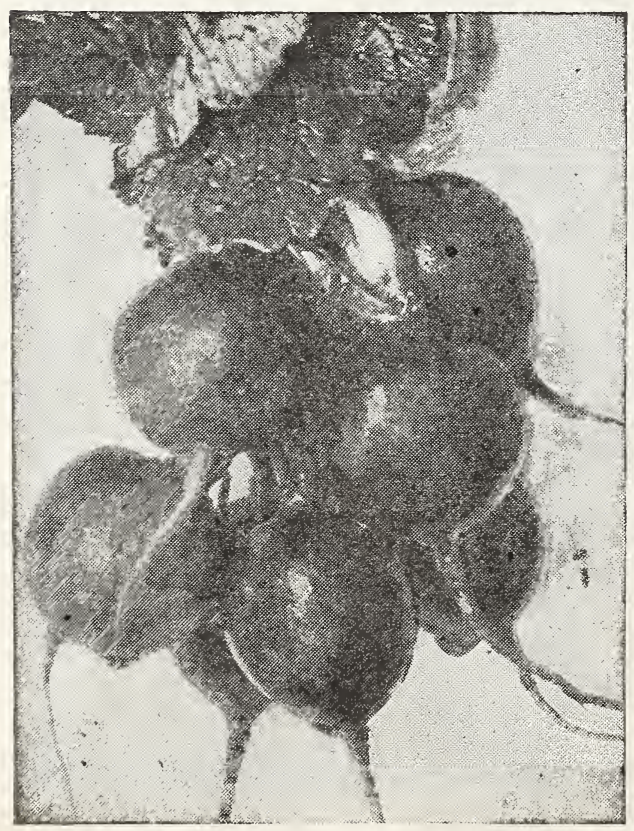

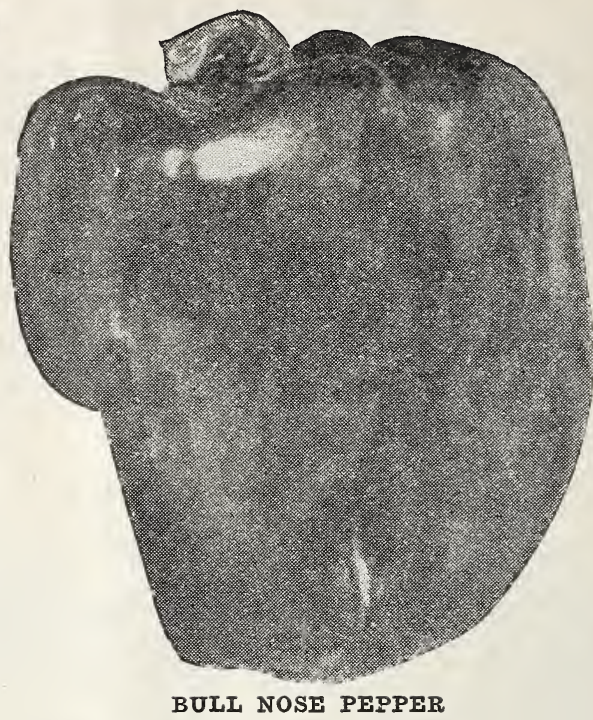

Radishes

Planting Directions-1 oz. to $150 \mathrm{ft}$. row. Good, rich, sandy loam is best. Sow as early as ground can be worked in spring in rows 12 to 18 inches apart and thin to about 2 inches apart. Sow every 10 days for a continuous supply. Winter radishes are sown in August and can be packed in sand for winter use.

EARLY SCARLET GLOBE-This is a splendid variety for outdoor planting or for hotbed or green house. Crisp and tender.

SCARLET TURNIP WHITE TIPPED-A favorite with market gardeners for outdoor planting, also for home garden; matures very early; turnip shaped; scarlet in color, with distinct white tip. Fine quality, crisp and tender. LONG SCARLET-An early Radish, much esteemed by some growers. Roots grow to about 3 inches in length; deep scarlet in color; flesh white and firm.

ICICLE-A fine white radish about 5 inches in length and quite slender. This is one of the very best of the summer radishes. Skin is smooth and thin; flesh fine grained, white and crisp.

FRENCH BREAKFAST-A quick growing, oliveshaped radish, about $1 \frac{1}{2}$ inches long. Color a beautiful deep rose scarlet, except for a little white at the blunt end. Fine for home garden use.

\section{WINTER VARIETIES}

ROUND BLACK SPANISH-A large turnipshaped variety. A general favorite. Skin black, flesh white and pungent; keeps well.

CHINA ROSE ROUND-This variety is of halflong shape, pink color, and flesh as solid as an apple; it has not that strong flavor which is peculiar to the Black Spanish, and keeps equally as well.

Prices on all Radishes-Pkt., 5c; 1 oz., 15c; 1/4 lb., 35c; 1 lb., $\$ 1.00$, postpaid. 


\section{Salsify or Veg- etable Oyster}

Planting Directions-1 oz. to $100 \mathrm{ft} . ; 8 \mathrm{lbs}$. to acre.

Requires a long season and a deep soil. Sow in rows $2^{3 / 4} \mathrm{ft}$. apart and thin to 6 inches between plants in row. Cover seed about $3 / 4$ inch. Salsify is hardy and can remain outside all winter. Prepared and handled the same as parsnip.

MAMMOTH SANDWICH ISLAND-Very mild and delicately flavored. Pkt., 10c; 1 oz., 20c; $1 / 4$ lb., 65c; 1 lb., $\$ 2.00$, postpaid.

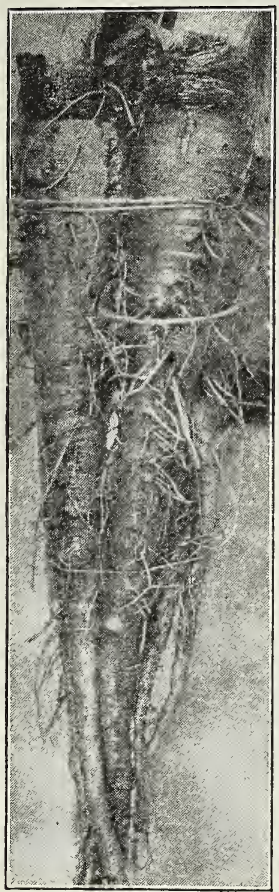

SALSIFY

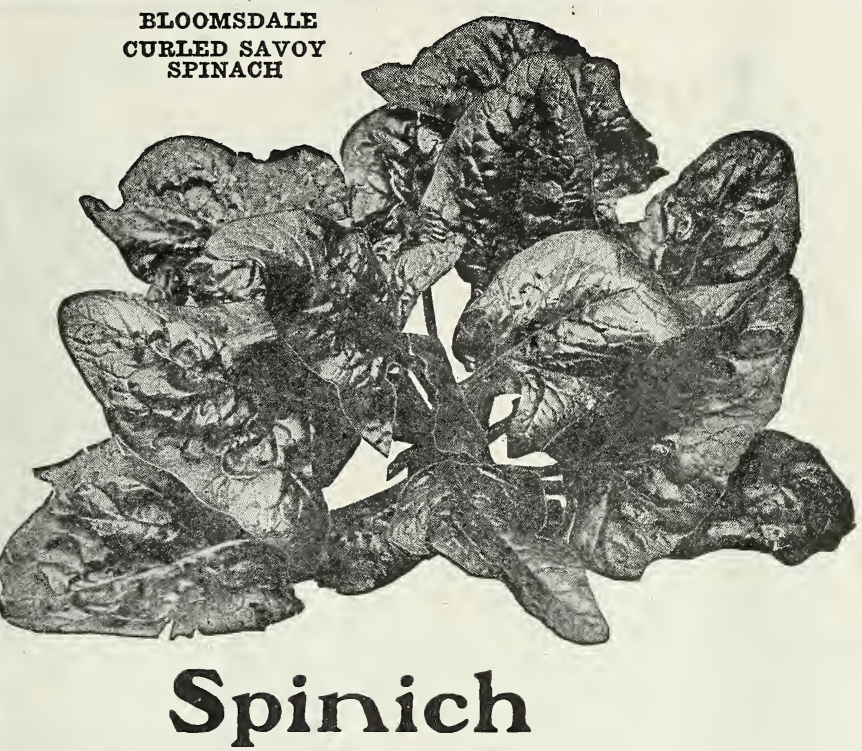

Planting Directions-1 oz. to $100 \mathrm{ft}$. row; 10 to $12 \mathrm{lbs}$. per acre.

Requires a very rich, loose moist soil. Spade or plow under well rotted manure in the fall. For spring culture the rows should be 12 to 18 inches apart and thin to about six inches between plants. Spinach can be sown in the fall for early spring use. Cover seedbed with straw, leaves, etc.

BLOOMSDALE CURLED SAVOY-Pkt., 5c; 1 oz., 10c; 1/4 lz., 20c; 1 lb., 60c; postpaid.

NEW ZEALAND, SUMMER_Pkt., 10c; 1 oz., 15c; 1/4 lb., 35c; $1 \mathrm{lb}$., $\$ 1.00$; postpaid.

\section{Squash}

Planting Directions-1 oz. to 20 to 40 hills; 4 to $6 \mathrm{lbs}$. per acre.

Sow in hills in the same manner and at the same time as cucumbers and melons the bush varieties 2 to 3 feet apart and the running varieties 6 to 9 feet apart. Fall crops can be made by planting in July or August. EARLY WHITE BUSH-The white scalloped "Patty Pan" or "Cymling" has for years been a favorite summer Squash, on account of its earliness, etc., but this new sort is a vast improvement; it is just as early, more prolific, and the squashes are much deeper; are easier prepared, contain less waste and almost twice the amount of flesh, which is of a finer quality. clear white color. Pkt., 5c; 1 oz., 15c; $1 / 4$ lb., 50c; $1 \mathrm{lb}$., $\$ 1.50$; postpaid.

YELLOW SUMMER CROOKNECK-One of the best of all Summer Crookneck Squashes. Of a dwarf, busy habit and very productive; bears early and all summer; true Crookneck type; rich bright yellow color; thickly warted. Its cooking qualities are unexcelled. One of the best varieties for the market or table use. Pkt., 5c; 1 oz., 15c; $1 / 4$ lb., 50c; 1 lb., $\$ 1.50$; postpaid. HUBBARD-Deservedly one of the most popular of the winter squashes. Oval shaped with both ends pointed; skin rough and dark green; shell very hard and tough; flesh thick, of bright orange color; dry, fine grained and of superior flavor. Excellent for pies as well as for baking. An excellent keeper and will often keep through the entire winter. Our strain is especially selected and very fine. Pkt., 10c; 1 oz., 20c; $1 / 4$ lb., 60c; 1 lb., $\$ 1.75$.

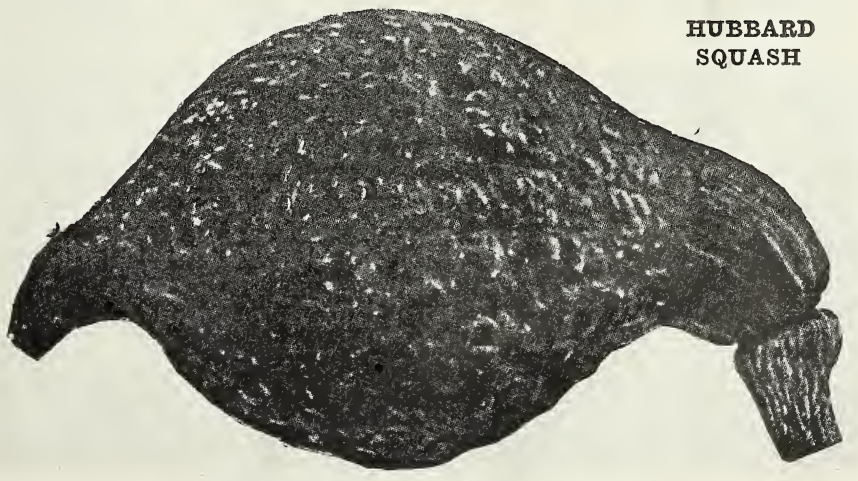




\section{Tomatoes}

Planting Directions-1 oz. for about 2,000 plants.

Sow inside in boxes or in hotbeds where the temperature is about 65 degrees. Transplant when 3 inches high to $3 \times 3$ inches each way. Transplanting will make an abundance of fibrous roots and also stocky plants. Plant outdoors when all danger of frost is past in rows $4 \mathrm{ft}$. apart and $3 \mathrm{ft}$. apart in row. Sunny exposure and fairly rich soil is best. Trim off part of foliage to expose tomatoes to the sun.

SPARKS' EARLIANA (92 days). Has easily gained the reputation of being the best first-early tomato. Pkt., 10c; 1 oz., 40c; 1/4 lb., \$1.25; 1 lb., $\$ 3.50$; postpaid.

EARLY DETROIT-The largest and best of the early purplish tomatoes. Largely grown throughout the South. Fruits very smooth, nearly globe-shaped, firm and of excellent quality. Pkt., 10c; 1 oz., 40c; 1/4 lb. $\$ 1.25 ; 1$ lb., $\$ 3.75$; postpaid.

EARLY ACME-One of the most popular purple varieties ever introduced. Usually free from cracks, round, solid and of good size. Quality and flavor very fine. Pkt., 5c; 1 oz., 35c; $1 / 4$ lb., $\$ 1.00 ; 1$ lb., $\$ 3.00$; postpaid.

NEW STONE (110 days)_Of large size, bright scarlet color, and will withstand rot and blight better than most other sorts. Pkt., 5c; 1 oz., 35c; $1 / 4$ lb., $\$ 1.00 ; 1$ lb., $\$ 3.00$; postpaid.

THE MATCHLESS-It is large, smooth and of very rich red color. Almost solid meat with very color. Almost solid meat with very little core and small seed spaces. A strong, vigorous grower and fruits heavily, the large size holding up to the end of the season. Pkt., 10c; 1 oz., 40c; 1/4 lb., \$1.25; 1 lb., $\$ 3.75$; postpaid.

LIVINGSTON GLOBE TOMATO-Of large size, maintained throughout the season, always smooth, firm fleshed, and has very fer, seeds, especially in the early fruits. Ripens evenly through and through. Pkt., 10c; 1 oz., 40c; 1/4 lb., \$1.25; 1 lb., \$3.75; postpair.

PONDEROSA-Often called "Beef Steak," orı account, of its large size and thick, solid flesh. Seed celis are small. Color a dark red, somewhat purple. Fruits weighing one pound

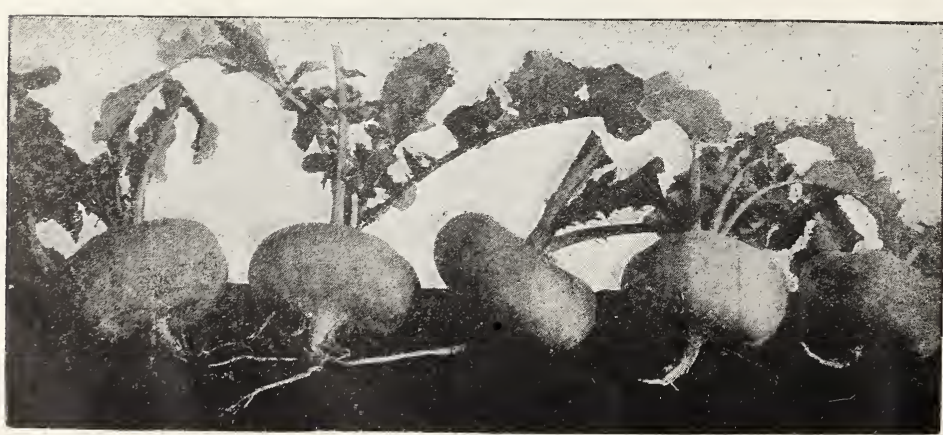

PURPLE TOP STRAP LEAF

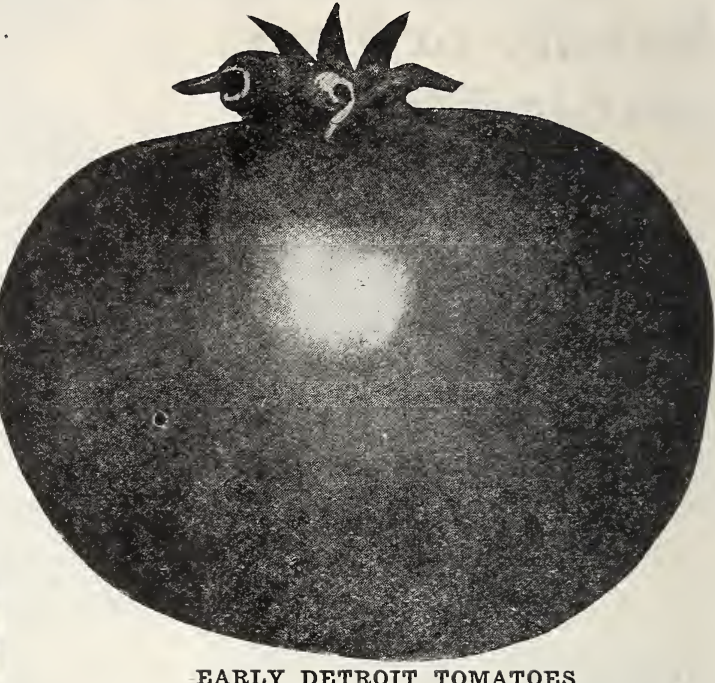

or more are not uncommon. Fine for slicing. Pkt., 10c; 1 oz., 50c; 1/4 lb., \$1.75; 1 lb., \$5.50, postpaid.

\section{Turnips}

Planting Directions-1 oz. to 150 ft. row; 1 lb to acre.

Turnips do well in a rich, light, sandy soil. Sow as early as the ground can be worked in spring in rows 15 inches apart and thin to 6 to 8 inches in row. Turnips need plenty of moisture and can be planted every two weeks or so up to late in August.

PURPLE TOP WHITE GLOBE-Popular in shape; good size and very attractive in appearance. The roots are reddish purple above the ground and white below.

PURPLE TOP STRAP LEAF-A popular variety for table use. Roots are flat, of medium size. Purple or dark red above ground, and white below. Delicious flavor.

LARGE WHITE GLOBE-Of good quality.

EARLY WHITE FLAT DUTCH-An excellent early white flat turnip; flesh mild.

YELLOW ABERDEEN-Large globe-shaped turnip with yellow flesh of fine quality.

AMBER FLÖBE-Grown chiefly for stock feeding; large size and excellent keeper.

SEVEN TOP-Used only for greens.

COW HORN-A long, whitefleshed turnip, growing half above ground; of fine quality. EARLY WHITE MILANEarliest flat white turnip; medium size, good quality.

PURPLE TOP MILAN-The same as White Milan except that it has purple top. RUTABAGA, PURPLE TOP -Hardy, productive, good keeper, yellow.

Price on all Turnips-Pkt., 5c: oz., 10c; $1 / 4$ lb., 25c; 1 lb., 80c; postpaid. 


\section{Herbs}

DILL-The seeds have an aromatic odor and warm, pungent taste. They are used as a condiment, and also for pickling with cucumbers.

ROSEMARY - The aromatic leaves are used for seasoning.

SAGE-The most extensively used of all herbs for seasoning.

SUMMER SAVORY - The leaves are used for flavoring.

SWEET BASIL-The leaves are used for flavoring soups, stews and highly flavored dishes.

SWEET MARJORAM-The leaves and ends of the shoots are esteemed for seasoning in summer, and also dried for winter use.

THYME-The leaves are used for seasoning.

\section{Roots}

\section{RHUBARB ROOTS}

These roots planted in good soil in the early spring will make a good growth, yielding stalks for the table the following spring. One year old, each, 25c; doz., \$1.25, postpaid. Two year old, each 50c; doz., \$3, postpaid.

\section{ASPARAGUS ROOTS}

Asparagus is one of the earliest and most delicious spring vegetables. Most people think Asparagus is hard to grow. This is a mistake. It grows rapidly from roots if given room, fertilizer and good cultivation. You will be fully repaid by having one of the earliest spring vegetables

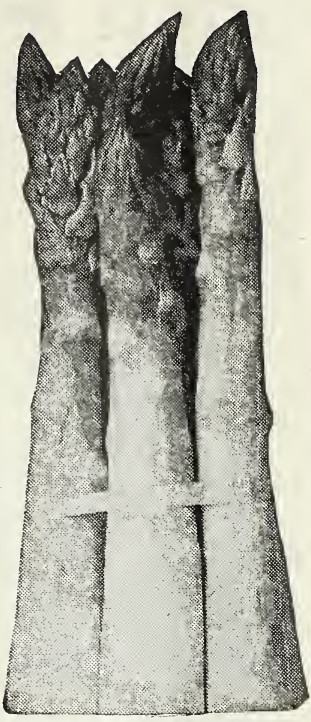

ASPARAGUS

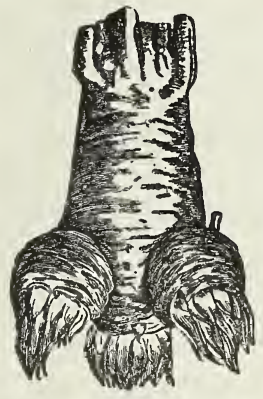

HOESE RADISH in your garden. We have two and three year old roots. One hundred plants for a bed 12 feet by 22 feet, which is large enough for an ordinary family. Two year old roots: Doz., 40c; 100 for $\$ 1.75$, postpaid. By freight or express: Doz., 30c; 100 for $\$ 1.50$. Three year old: Doz., 60c; 100 for $\$ 2.50$; postpaid. By freight or express: Doz., 50c; 100 for $\$ 2.00$.

\section{HORSE RADISH}

A very profitable crop in many places. Gardeners near any good market can make big money raising this root. Doz., 40c; 100 for $\$ 2.00$, postpaid.

\section{ARTICHOKES (Jerusalem)}

Best hog food known. Easily grown. Three bushels seed an acre, enough to keep 20 to 30 hogs from October to April. Cut and plant like potatoes. $1 \mathrm{lb}$., 30c, postpaid. By freight or express: Peck, 90c; bu., $\$ 2.75$.

\section{Vegetable Plants}

These plants are grown in Hotbeds and Cold Frames and are ready for shipment the latter part of February. All plants are sent by express or parcel post at purchaser's expense. By parcel nnct add $5 \mathrm{c}$ per dozen or $15 \mathrm{c}$ per hundred. Plants can be sent better by express than parcel post. as they can be packed more suitable for shipment.

\section{TOMATO PLANTS}

(Not transplanted) -15c per dozen; $75 \mathrm{c}$ per $100 ; \$ 5$ per 1,000 .

(Transplanted) $25 \mathrm{c}$ per dozen; $\$ 1.00$ per 100; $\$ 8$ per 1,000.

Stone

Early Detroit

Earliana

Ponderosa

Acme

\section{EGG PLANT}

25 c per dozen; $\$ 1.00$ per 100 .

New York Purple

Black Beauty
CAULIFLOWER

25 ₹ per dozen; $\$ 1.00$ per 100 .

Earīy Snow Ball

Danish Giant

CABBAGE PLANTS $40 \mathrm{c}$ per $100 ; \$ 3.50$ per 1,000 . field Early Jersey WakeCharleston Wakefield

Early Winningstadt Early York. Late Drumhead Early Summer Early Eureka Late Flat Dutch
SWEET POTATO SLIPS

(Ready for shipment by April 10.)

VINE VARIETIES

$35 \mathrm{c}$ per $100 ; \$ 3.00$ per 1.000 .

Genuine Yellow Yam Southern Queen

Strasburg

BUNCH VARIETIES $35 \mathrm{c}$ per $100 ; \$ 3.00$ per 1,000 .

Bunch Yellow Yam

Nancy Hall

Early Triumph

Golden Coin
PEPPER PLANTS

25 c per dozen; $\$ 1.00$ per 1,000 .

Long Cayenne

Bell or Bull Nose

Sweet Mountain

Chinese Giant

LETTUCE PLANTS

35 c per $100 ; \$ 2.50$ per 1,000 .

California

Early Cabbage

Big Boston

St. Louis Market

Deacon Head

Hanson Head 


\section{Irish Potatoes}

IRISH POTATOES - Ten bushels per acre, or 1 peck to 125 hills, in drills 3 feet apart, 3 or 4 cuttings to one potato. Plant from February 1st to April 1st. Produce 90 to 200 bushels per acre, maturing in 105 days-May 25th to June 5th. One sack holds ten pecks.

Our Seed Potatoes are all specially grown for seed purposes in the best potato districts in Maine.

We do a large business in Seed Potatoes, our trade every year experiencing a constant and steady growth, resulting from the fact that our seed potatoes have acquired the very best reputation for quality, productiveness and satisfactory crop results.

Culture of Potatoes-Potatoes are usually planted in rows 3 feet apart, and the cut-pieces one foot apart in the row. Cut two eyes to the piece. Do not use stable manure on Irish potatoes. Irish potatoes, turnips and oats follow each other well.

For Succession Irish potatoes can be followed by watermelons, about June 1st, and by spinach, turnips and winter radishes in October.

Potato Diseases-For blight spray with Bordeaux Mixture. For Potato Bug-See Insecticide page - the best preparation, however, being the dusting, 4 pounds per acre, of powdered Calcium Arsenate. Irish Potato Scab-To one pint formalin add 35 gallons water in a barrel. Soak potatoes as held in a bag $1 \frac{1}{2}$ hours. Potatoes by weight-The law compels us to sell potatoes by weight-bag 150 lbs. Bushel, 60 lbs. Peck, 15 lbs.

IRISH COBBLERS-The tubers are a beautiful creamy white, eyes strong, well developand slightly indented, which in potatoes always proves a distinctive mark of fine quality. Peck, $\$ 1.00$; bu., $\$ 3.00$; by freight or express.

EARLY RED BLISS TRIUMPH-An extra early potato, round in shape, pink skin, white

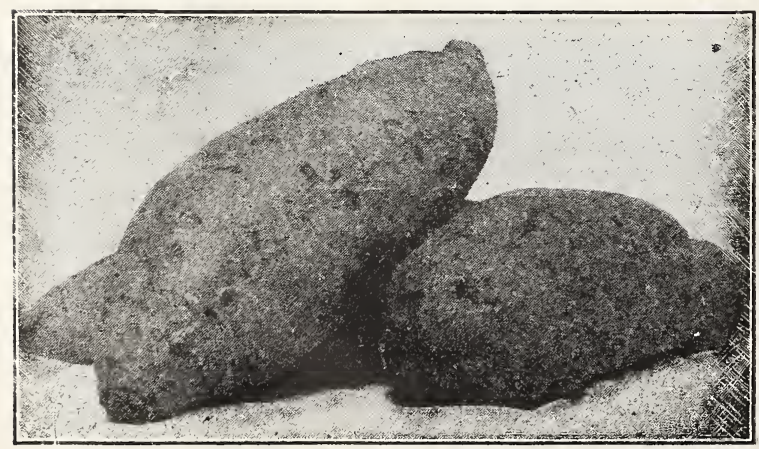

flesh, and of handsome appearance. This seems to be specially adapted to Southern soil and climate, and is a great favorite with Southern truckers. Peck, $\$ 1.00$; bu., $\$ 3.00$, by freight or express.

EARLY ROSE-The Rose still continues one of the most popular varieties in our list. Productive, of most excellent table qualities, and a satisfactory all-around early variety. Peck, $\$ 1.00$; bu., $\$ 3.00$, by freight or express.

LOOKOUT MOUNTAIN POTATOES-A distinctive type potato and sown only in summer for fall crop. Make orders early in season; deliveries between June 1st and July 15th, not later-cash with order. Tubers often weigh 2 pounds. Harvest about November 1st. Potatoes will keep in ground all winter.

Potatoes by Weight-We quote and sell Lookouts by weight. Bag, 1371/2 lbs. Bushel, $55 \mathrm{lbs}$. Peck, $133 / 4$ lbs. Deliveries made between June 1st and July 15th, not later. Peck, $\$ 1.50$; bushel, $\$ 4.50$.

\section{Sweet Potatoes}

Sweet Potato Culture-We set out draws here in March, April and May, and set out vine cuttings June and July-8,000 per acre. Usually rows are 4 feet apart and plants are 18 inches in drill. Average yield in United States per acre 94.5 bushels. Standard weight Spring 55 pounds per bushel.

For bedding use small potatoes whole; cut large ones in half and bed with the eyes up.

Often yield 175 to 200 bushels per acre; 200 pounds Acid Phosphate is a good fertilizer. Do not use nitrate of soda.

NANCY HALL, PORTO RICO, BUNCH and YELLOW YAMS, TRIUMPHS and GOLD COIN. Peck, $\$ 1.00 ; 1$ bushel, $\$ 2.50$, by freight or express. 


\section{Selected Seed Corn}

Crops are dependent upon pure seed to bring forth large yields. Therefore the seed which you place into the ground is of prime importance to the planter who wants large yields. It took us thirty-five years of constant study and work to bring our types of corn to their present day perfection. We grew corn in Iowa, Illino is and Ohio, trying to find the location best suited for the production of good corn for the Southern planters. After numerous tests and much work we came to the conclusion a few years ago that Tennessee produces the heaviest, sturdiest corn in the world. The result is the Harpeth Valley Seed Farms.

Our Harpeth Valley Seed Farms are located in Middle Tennessee which, with its rich Phosphate Gravel lands is the greatest seed corn producing district in the world.

The long, dry Fall gives corn the greatest chance to thoroughly dry out and retain the highest vitality. Unlike Northern grown corn, which is always liable to have the germ killed in the late Fall from freezing while full of moisture, our corn is cured and matured in God's sunlight and the pure open air. No drying houses in Middle Tennessee-nature does this.

SEED CORN ADAPTED TO OUR LOCALITY-One, if not the most important things to consider in buying seed corn is to get the corn best suited to your soil and locality. All corn breeders and demonstration corn experts will tell you that Northern Corn will not do in the South the first year. Our Mr. Ullathorne has thirty-five years' experience in breeding corn and knows.

We own, operate, lease and control over 3,100 acres. Our storehouses and warehouses are equipped with the most modern machinery for handling seed stocks accurately and promptly.

\section{ULLATHORNE'S Champion 90 Day White}

The ideal corn for the south is an early variety, that will produce a big yield before the drought sets in. Ullathorne's Champion 90-Day White is such a corn. It is the Earliest Large White Corn in the World! It is an Early White Dent, coming in almost as early as the Adams Early but much larger; sample ears have been shown us 14 inches in length and $3 \frac{1}{2}$ inches in diameter. For stock feeding it is very valuable, coming in as it does when all fodder is short, it fills a breach which all stock feeders can appreciate. Again, it is a corn which has made itself before the hot dry weather, when all field varieties must make their growth.

TWO CROPS OF CORN A YEAR can be made on the same ground, making it doubly profitable to grow. The constantly increasing demand for this corn is sufficient proof for all we claim for it.

Although a planter may have plenty of corn in his crib, it pays to buy his Seed Corn every year. Every planter knows how quickly a type of corn runs out. Fifteen days often proves to be a critical time of ear formation and maturity and the whole crop is either ruined or made, just as you plant your own corn or our Early Thoroughbred Seed Corn. Many planters say if they had not planted our Champion 90-Day White Corn last year they would not have had any corn, as their own grown corn crop was an entire failure.

Description-The accompanying illustration is a true picture, from a photograph of this corn, showing its general type and character. Every stalk produces from one to two good ears, and this is where its
large, heavy yields come in. The stalks are large, robust, height of 8 to 12 feet, dependent upon land, has a very heavy and extensive root system and this is where its vitality to resist drouth and hot weather comes in. Ears run from 10 to 13 inches long, but usually 10 inches, 16 to 20 rows, deep kernels with large, full germs, firmly set on a pure white cob of medium size. In short, we breed this corn with a single eye to heavy yields and early maturity and not for show purposes. Send for sample grains.

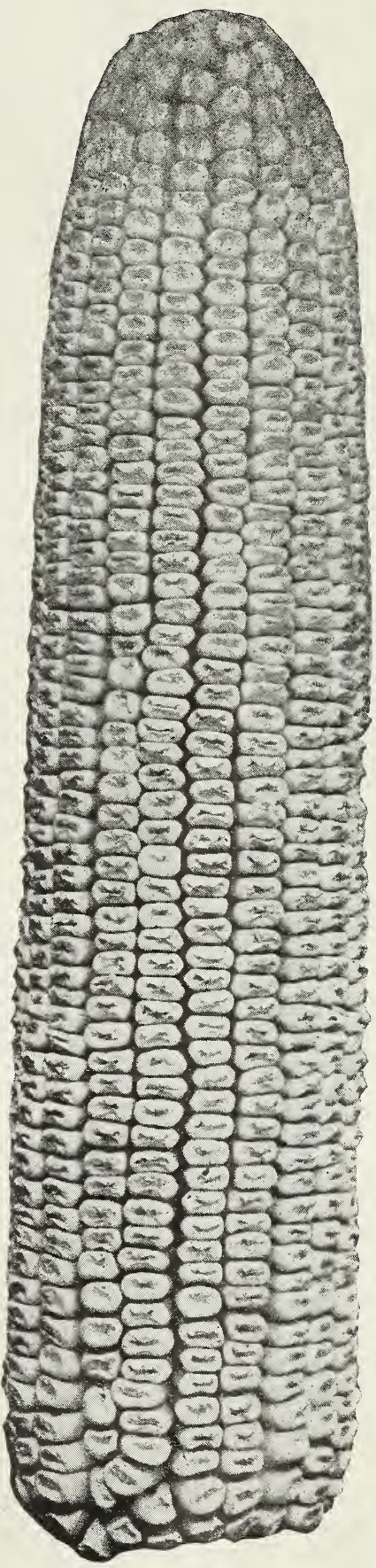




\section{Ullathorne's Paymaster Corn}

Ullathorne's Paymaster-the 100 per cent Two-Ear Corn-will outyield any corn in the world! We breed it up to produce heavier yields of small red cob, deep grain corn, than any other variety in existence. This is an absolutely 100 per cent two-ear corn, many stalks with three and four ears. We have gone through our fields time and again looking for stalks with less than two ears and we have yet to find one.

A deep, white grain on a small red cob, stands the drought, has a short stocky stalk, does not blow down easily, and will mature anywhere in the south, as it is strictly a 100-per cent variety. Big Yielder -75 to 12 j bushels per acre-according to soil. Read what our customers who planted this corn.say about it, also the following Corn Va-

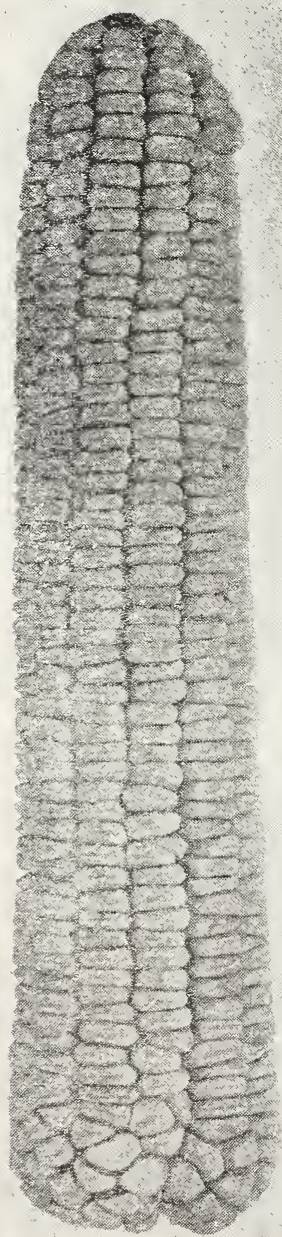
riety Test by the Mississippi A. \& M. College in 1918:

Planted April 5th, 1918, on moderately fertile valley land.

Bu. per acre

Variety

(ear corn)

Station Mosby ........... 43.1

Woodruff's Mosby ........... 36.7

Mosby $421 \ldots \ldots \ldots \ldots \ldots . \ldots . . . .43 .5$

Station Vardaman ......... 42.8

Cocke's Prolific ............ 40.5

Jones' Prolific . . . . . . . . . . . 39.8

Alabama Yellow .......... 38.3

Boone County White ......... 40.3

North Carolina Prolific ....... 40.5

ULLATHORNE'S PAYMASTER $\mathbf{4 6 . 6}$

A yield of 3.01 bushels more per acre than any other variety, or enough to pay for seed corn to plant six acres at $\$ 4.00$ per bushel if feed corn is selling at $\$ 2.00$ per bushel.

You cannot afford to plant crib selected corn. Seed Corn at $\$ 10.00$ per bushel is cheap if it will produce results such as our Ullathorne's Paymaster. Our seed stock of this variety is exceptionally fine this year and we hope to be able to fill all orders that come to us, large or small. If you are looking for the corn that will make you the most bushels and the most money, stop right now and order enough Ullathorne's Paymaster to plant your entire crop. It's the corn that will do it. Plant Ullathorne's Paymaster on good land and do your part and it will make you 100 bushels GIANT TENN. RED COB

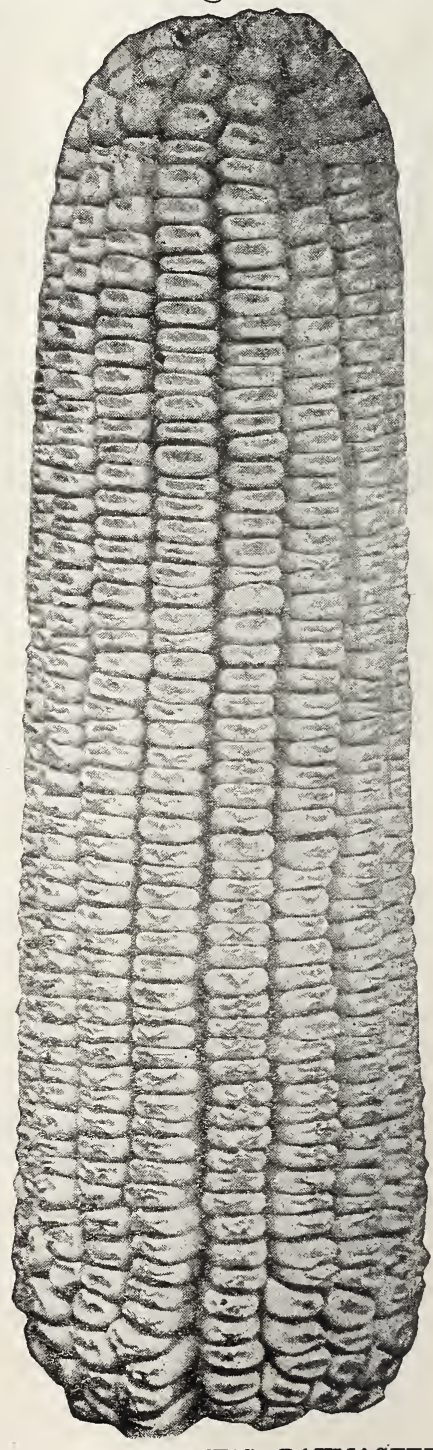

ULIATHORNE'S PAYMASTER

Gentlemen: The seed corn I bought of you (Paymaster) was planted July 2nd and was in eating condition about first week in September. I think it will turn out forty bushels per acre and will do to crib about 1st to 10 th of November. Expect to want more another year. Yours truly, R. M. WEISSINGER.

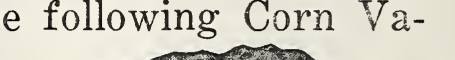




\section{ULLATHORNE'S \\ Giant Tennessee Red Cob White}

Without a doubt this is the largest yielding and one of the highest feeding and best milling corns in the world. For ensilage it cannot be surpassed. The stalks are 8 to 12 feet high, broad and short jointed, foliage broad leaved and full. Ears are 9 to 13 inches long, 16 to 22 rows, with a deep, broad grain, pure white on a red cob of medium size, averaging one large and one small ear to the stalk. The judges at the 1917 Tri-State Fair would not permit our Giant Tennessee Red Cob Corn to enter competition as they stated the ears were so large that they were "out of proportion." It is the most ideal corn we have ever seen grown in any corn growing section.

\section{Ullathorne's Mastadon Tennessee Red Corn}

Won Championship of entire Corn Show at Memphis and Nashville, Tennessee, Fall 1919, in competition with the entire South.

Mastadon Tennessee Red is an early maturing corn and a great favorite wherever known. It is superior for Feeding and Silage, stock feeders claiming one bushel is equal to $1 \frac{1 / 4}{4}$ bushels of ordinary corn. This corn is by no means as handsome as some of our other varieties, but it is iron-clad and of intense vitality to resist unfavorable conditions-cool nights, extreme wet or dry weather and can always be relied upon to make a crop when others fail.

Mastodon Tennessee Red Corn is a very large variety of unusual size and length. On good land the ears will run from 11 to 13 inches, with occasional specimens 14 inches long. Grains 5-8 inch long and very wide and thick. Fourteen to sixteen rows. This is another triumph of Mr. Ullathorne's skill as a corn grower and breeder as shown by the following from Mr. E. P.

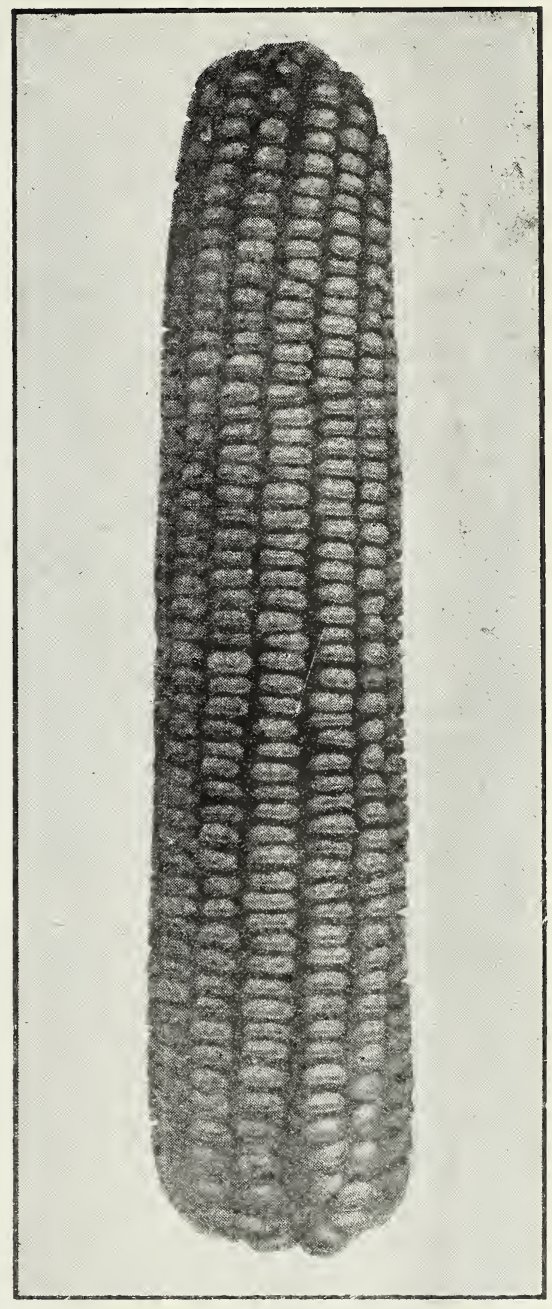

MASTADON TENNESSEE RED Mangum, Tunica, Miss.: "My crop of Ullathorne's Mastadon Tennessee Red Cob Corn was a wonder to my neighbors. I sent four ears to the Merchants Exchange, Memphis, that weighed seven pounds." Send for sample grains.

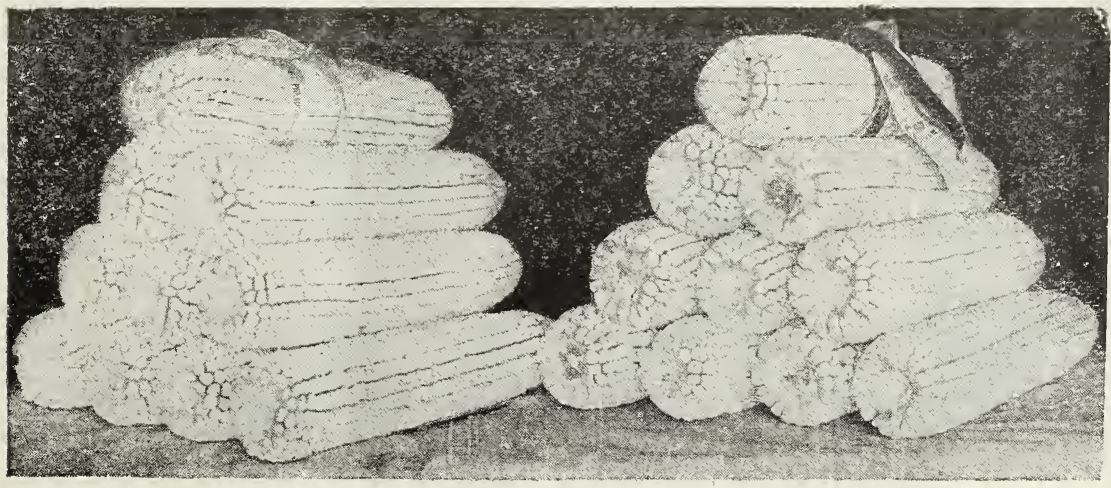




\section{EXTRA SELECT Mosby Prolific Corn}

We are breeding our stock of Mosby to grow not over ten feet high, to grow with a heavy stalk as thick as your wrist at the ground and tapering to a whip-like top. Two to three ears to a stalk is our aim. We don't care to produce more than this number as we want to get the growth out of the long stalk and into the ears. Ears of our Mosby are from one to two inches longer than ordinary stock, with very small cob and deep, pearly white grain. This is just the ideal Prolific Corn for those who care for this variety; it will not rot under the influence of too much moisture and will stand a good deal of drouth. Matures in about 130 days. Send for sample grains.

\section{Ullathorne's Mammoth White June Corn}

Our strain of June Corn is vastly superior to the Mexican June as we consider this variety a mongrel of the worst type. The Mammoth White June Corn is a beautiful snowflake white, soft and of fine texture. Ears average eight to ten inches,

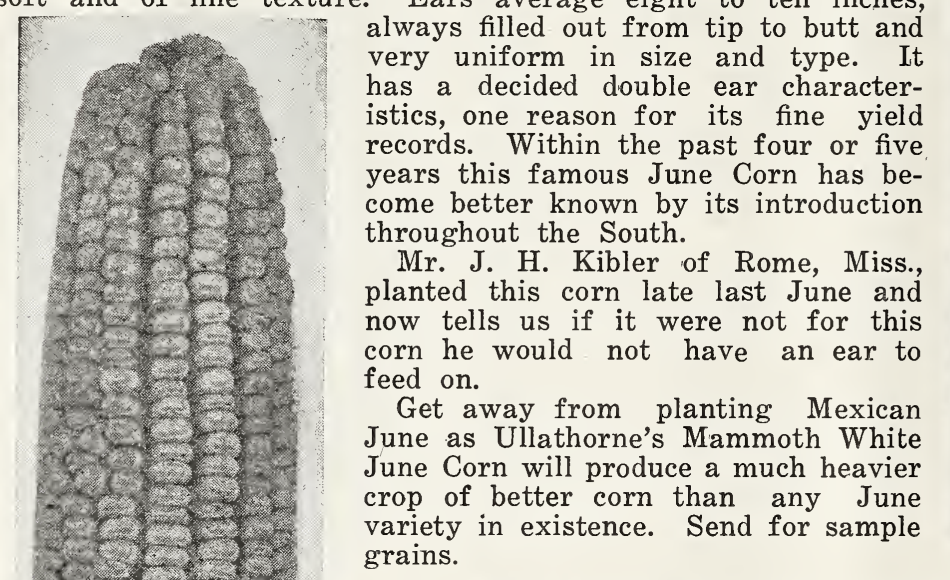

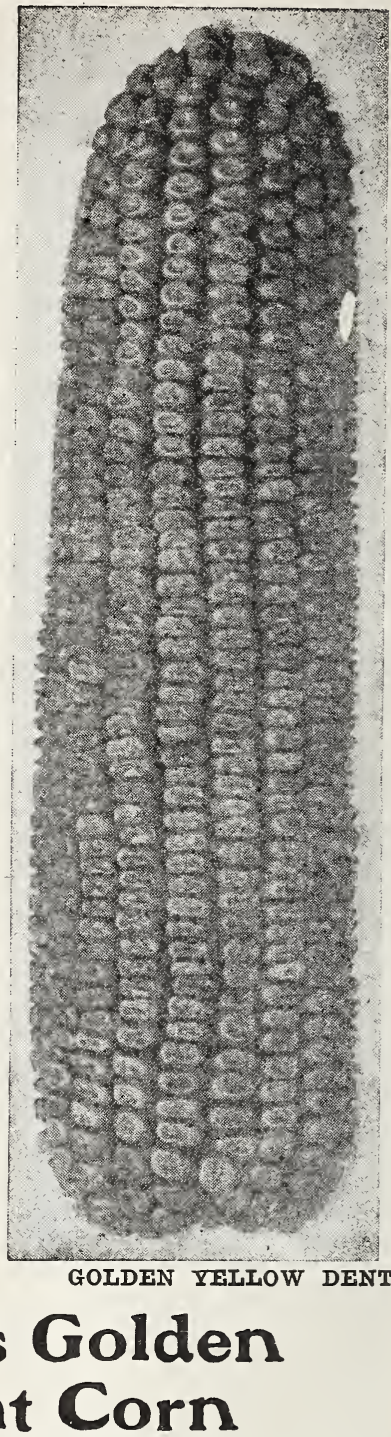

Developed by our Mr. Ullathorne at the same time he was developing our famous Champion 90-day White Corn. Large Golden Yellow Dent is an early 90-day corn and matures considerably in advance of the ordinary Southern varieties. A beautiful Rich Golden Color; large, deep grains with large, oily germs; medium cob, 16 to 22 rows, many ears weighing a pound and a half each. While not a two-ear variety many of our customers class it as such, but we know it will yield about 85 per cent two ears to each stalk. We have yet to find a field of this variety with over 5 per cent barren stalks. The stock and chicken feed manufacturers always pay a premium for this rich colored corn. After our stocks are sold, we will have no more to offer as we do not buy a grain of corn from other growers. Send for sample grains.

October 8th, 1919.

Gentlemen: Was more than pleased with the seed corn I got of your firm this spring. Your Paymaster certainly made me a good crop. I think anyone would be pleased with it or any other of your seed corn. I was told several times that I had as good corn as was grown in the regular corn belt. Respectfully, R. E. ROSE.

\section{PRICE ON ALL SEED CORN}

One lb., 30c; 5 lbs., $\$ 1.00$, postpaid. Prices on larger quantities see Field Seed Special Price List 


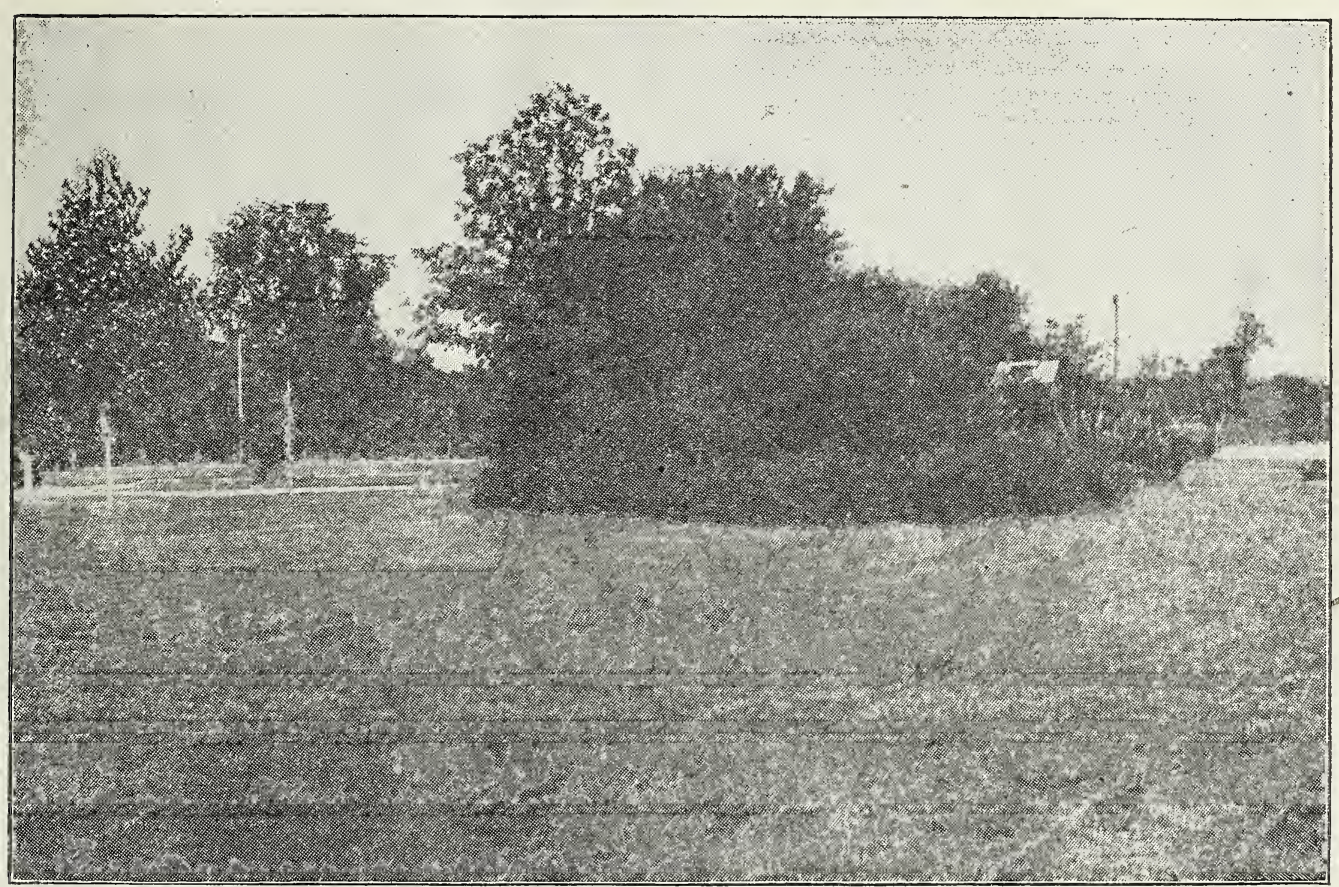

\section{Grass Mixtures}

\section{Ullathorne's Special Lawn Mixture}

The essentials for a fine lawn are: First, a rich, well drained soil; second, careful preparation of the ground, making it as fine and smooth and mellow as possible; third, a wise selection of seeds; fourth, sowing at such a time as to give the young plants a chance to become well established before being subjected to very dry or cold weather, or to the direct rays of the hot summer sun.

We have made a special study of lawns and lawn grass mixtures to secure the best results and we are offering you in Ullathorne's Special Lawn Mixture the results of years of study and close observation.

Ullathorne's Special Lawn Mixture-1 lb., 40c; postpaid.

\section{Timothy and Alsyke Mixture}

We received last season a very large number of orders from our customers for this excellent combination hay and pasture mixture, it is specially suited to low, moist lands where other grasses invariably fail. Under such conditions it can be depended upon to produce heavy yields either for pasture or hay. Stock prefer this combination to Timothy alone, its value for feed is considerably higher. A great many farmers grow this mixed seed in preference to other grasses and clovers as the two varieties do well together, they are adapted to the same kind of soil and mature at the same time, and are wonderfully prolific for very rich hay. One lb., 40c, postpaid.

\section{Permanent Pasture Mixture}

There are a number of grasses which grow in this country which make excellent pasture at some season of the year, but none that will furnish good pasture from early spring until winter snow. This fact and the fact that we are seed specialists caused us to experiment with a combination of grasses which would produce a permanent pasture. With our knowledge of the growth and formation of the different grasses, and after several years of experimenting, we have succeeded in producing a permanent pasture mixture, a combination of grasses of different habits and seasons of growth and can be depended upon to produce a turf that will stand the trampling of the stock and forms a heavy turf, that withstands the extreme heat, cold and dry weather. 1 lb., 40c; postpaid.

\section{Permanent Meadow Mixture}

The person who intends to put out a meadow for cutting for hay, year after year, or a pasture that is intended to be permanent, will obtain the best results by using our Permanent Meadow Mixture. $1 \mathrm{lb} ., 40 \mathrm{c}$, postpaid.

\section{Chicken Pasture Mixture}

A splendid mixture for green feed for chicken runs. 1 lb., 40c, postpaid.

USE ULLATHORNE'S INOCULATING BACTERIA ON ALL CLOVERS. SEE PAGE 32. 


\section{Grasses}

KENTUCKY BLUE GRASS-Is at its best in Spring and Fall months. For lawn purposes it is the standard and superior to any other sort. Under favorable soils it will withstand all variations in weather and climate. 1 lb., $45 \mathrm{c}$, postpaid.

ENGLISH BLUE GRASS-The grass is a very permanent one and is especially valuable for permanent pastures where the soils are not too dry. 1 lb., $45 \mathrm{c}$; postpaid.

ITALIAN RYE GRASS-Admirably suited for hay and pasture. Will give excellent winter pasturage. Withstands extremes of temperatures and remains grèen throughout the winter. 1 lb., 35c; postpaid.

JOHNSON GRASS-Looked upon as a pest, but makes a good perennial hay and pasture grass. A great drouth resister and much used in the Southern States. $1 \mathrm{lb.}$. 40c; postpaid.

BERMUDA GRASS-A very valuable grass in the warmer climates. In the Southern States it is cultivated extensively and is most highly prized, chiefly for grazing, all kinds of stock being exceedingly fond of it. It is also good for lawns. 1 lb., 70c; postpaid.

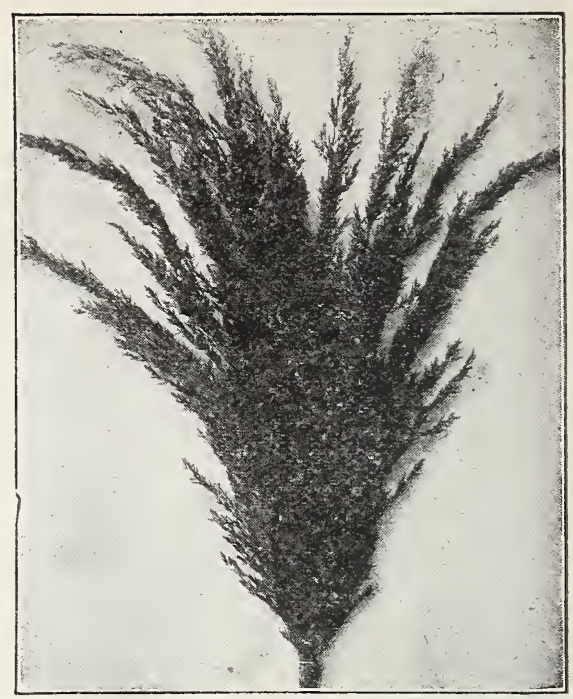

RED TOP HEADS
RED TOP or HERD'S GRASS-This is one of the most generally useful agricultural grasses we have. It will grow upon every soil and give entire satisfaction to the farmer. It is not only a good meadow grass, but is one of the best pasture species, grazing: being a benefit and almost a necessity for its perpetuation and preservation. In a moist soil it does the best, and in swampy places that would otherwise produce nothing in the grass line, Red Top will thrive with the greatest vigor. Re-cleaned seed only. $1 \mathrm{lb}$., $40 \mathrm{c}$; postpaid.
SUDAN GRASS-A new forage crop of immense value. Yields two to four tons per acre. Sow in April, 3 lbs. per acre in drills or 14 to $20 \mathrm{lbs}$. per acre broadcast. Can be cut two or three times during the season. $1 \mathrm{lb} ., 35 \mathrm{c}$, postpaid.

TIMOTHY - The most popular of all grasses for hay and the standard to which all other hay is compared. It is a perennial, and does well on almost any kind of soil. Hay should be cut just when it has stopped flowering. 1 lb., 40c; postpaid.

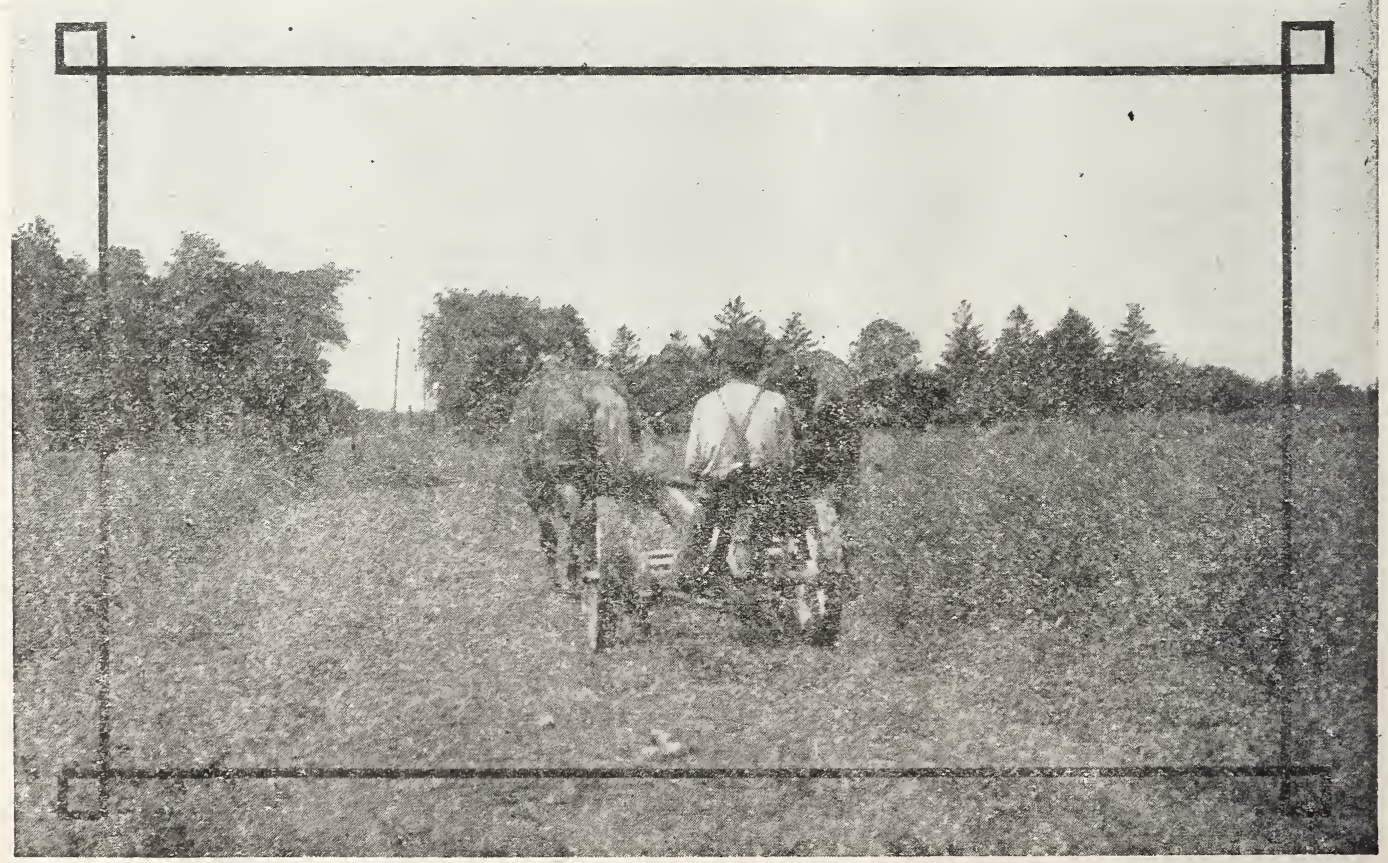




\section{High Grade Clover}

ALFALFA-Alfalfa once established is such a profitable crop that every farmer can afford to take great pains to obtain a stand. So much has been written concerning the high feeding value of this crop, its wonderful yields and fertilizing value to the land, it would be wasted time and space to go into details. Soil must be thoroughly drained and prepared by deep plowing and harrowing. Sow 20 to $25 \mathrm{lbs}$. per acre in March and April and September and October. Dakota, No. 12, 1 lb., 50c, postpaid. Fancy Western, 1 lb., 40c; postpaid.

RED CLOVER-A valuable crop, largely used for pasturage and soil improvement. Sow 10 to 12 lbs. per acre in September or March. 1 lb., 50c; postpaid.

MAMMOTH or SAPLING CLOVER-Very rank grower; succeeds better on thin land than Red Clover. Sow 10 to 12 pounds per acre. 1 lb., 50c; postpaid.

ALSYKE CLOVER-Thrives well on damp soils or where it is impossible to secure a catch with Red Clover. Sow 6 to 8 pounds per acre. 1 lb., 45c; postpaid.

WHITE CLOVER-Valuable for lawns and permanent grazing pastures. Sow in Spring, 4 to 6 pounds per acre. $1 \mathrm{lb}$., 85c; postpaid.

CRIMSON CLOVER-An annual. Should be sown in August or September. Furnishes excellent Winter pasture and improves the soil wonderfully when plowed under. Sow $15 \mathrm{lbs}$. per acre. 1 lb., 30c; postpaid.

JAPAN CLOVER (Lespedeza)-Best known and most valuable clover for the South. Improves poor land and will produce a good hay crop, where cotton and corn cannot be grown profitably. Sow 20 to 25 pounds per acre in March or April. 1 lb., 40c; postpaid.

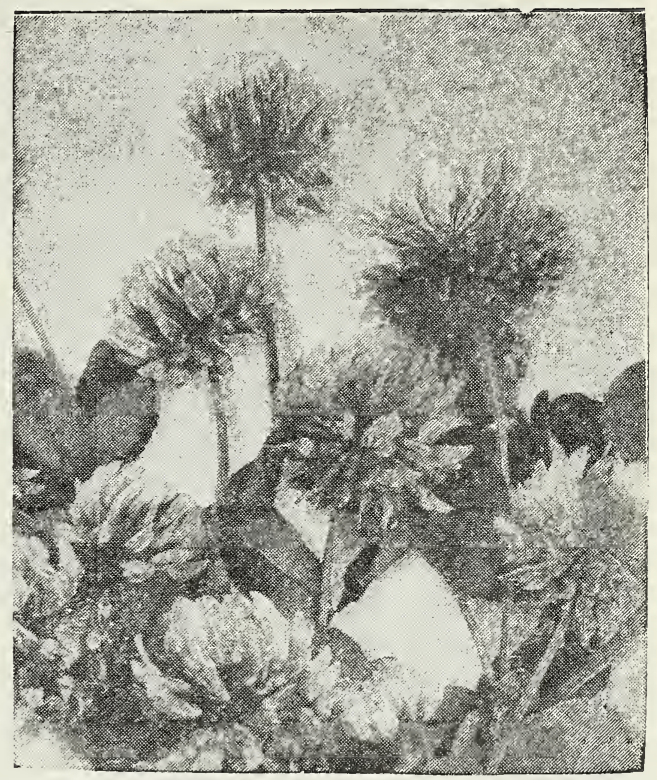

MELILOTUS or SWEET CLOVER-Grows only on lands which carry a large per centage of lime. Sweet Clover occupies a place in the crop rotation which cannot be filled by any other crop, for it is without doubt the greatest soil improver of the age. Hulled Seed, 1 lb., 50c; postpaid.

BURR CLOVER-An annual. Sown in August or September. 20 lbs. in burr or 10 lbs. hulled seed per acre. 1 lb., hulled seed, $50 \mathrm{c} ; 1 \mathrm{lb}$., in burr, $35 \mathrm{c}$; postpaid.

Inoculate all Clovers with ULLATHORNE'S INOCULATING CULTURE for best results.

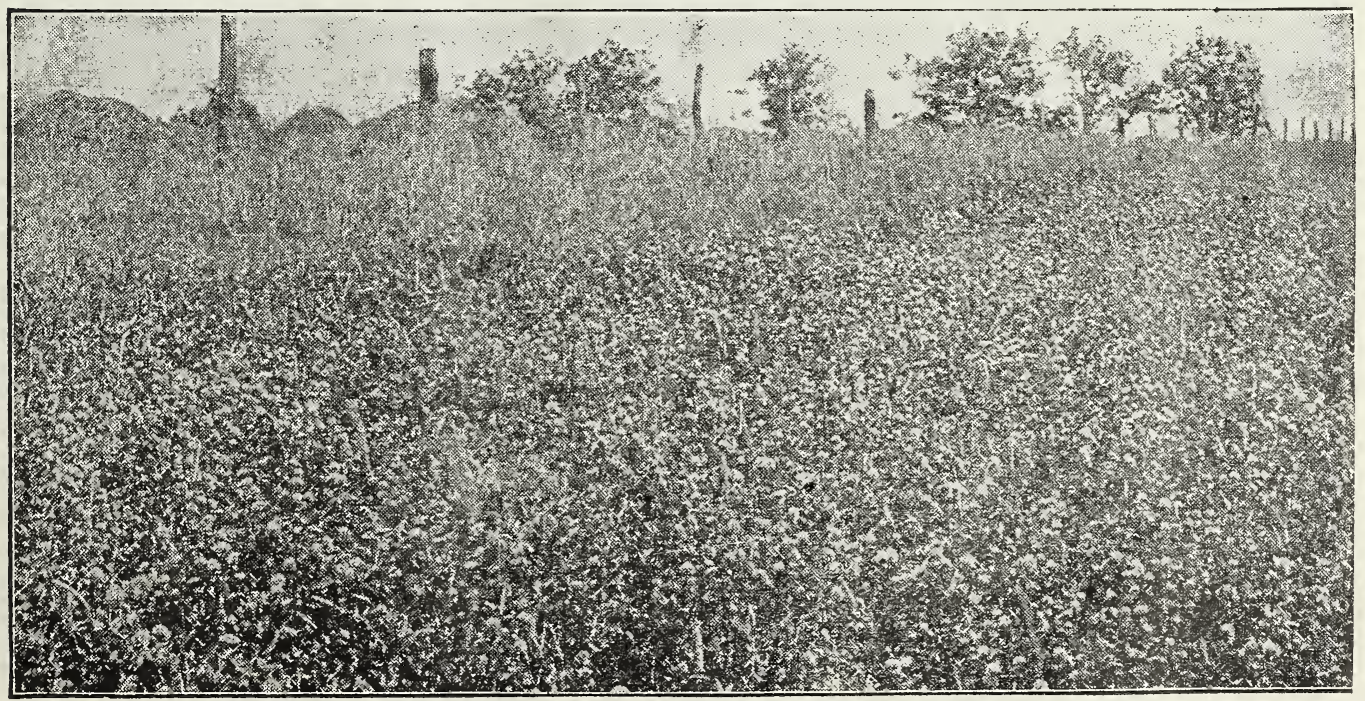




\section{Sorghum or Cane}

For best quality hay sow two to three bushels per acre; for sorghum or grain drill $1 / 2$ peck per acre from April to August.

TEXAS SEEDED RIBBON CANE-Closely resembles the true Ribbon Cane raised from cuttings. It is an old and well known Sweet Sorghum and is highly prized by Sorghum syrup makers for its rank and vigorous growth and heavy juicy stalk, which produces a large yield of syrup. It matures late but makes a heavy growth of green foliage for feeding stock and filling silos. $1 \mathrm{lb}, 40 \mathrm{c}$; postpaid.

RED TOP SORGHUM-Is the great hay "Cane" or Sorghum for the South. On account of its slender stalks and abundance of leaves, it is most desirable for hay. It is also quite rich in sugary substances, good for silage and often planted for sorghum syrup. It grows five to six feet high. Is a good drouth-resister. 1 lb., 25c; postpaid.

EARLY AMBER SORGHUM-An old and well known variety, grown in many parts of the South and Southwest for hay and sometimes for sorghum. We do not especially recommend it for sorghum, however, as there are other varieties which will make much more sorghum per acre. It is early or quick maturing and has a flavor that is attractive. 1 lb., 25c; postpaid.

EARLY ORANGE SORGHUM-Largely used for hay and fodder. Taller and heavier than Amber. Is an old and popular variety in many sections of the country. 1 lb., 25c; postpaid.

JAPANESE HONEY SYRUP CANE-It has slender reddish heads and matures in 120 to 125 days and is especially desirable for syrup making. When planted for silage it has made as high as 17 tons per acre. The best for making syrup ever introduced. 1 lb., $40 \mathrm{c}$; postpaid.

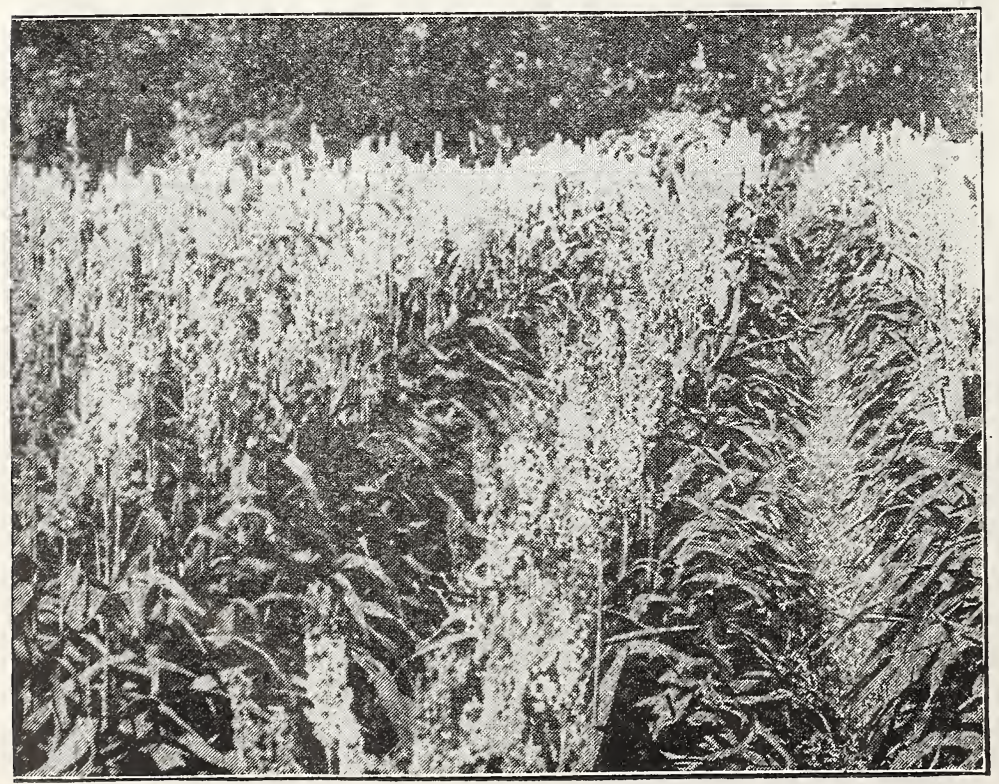

\section{Non-Saccarine Sorghum}

Sow all of these from April to May, 10 lbs. in drills; $1 \mathrm{bu}$. broadcast to the acre.

RED KAFFIR CORN-This very leafy and juicy variety is taller but more slender than the white; ripens a little earlier and yields heavier. It is also valuable for sowing on poor land. 1 lb., 25c; postpaid.

WHITE KAFFIR CORN -Grows four to five feet high, with numerous wide leaves; 2 to 4 heads per stalk. 1 lb., 25c; postpaid.

YELLOW MILO MAIZE -The plant suckers abundantly and produces tall, slender and succulent leaf stalks. The seed is a compact, sorghum-like head. It produces an enormous quantity of fodder, for which stock show a marked partiality. 1 lb., 25c; postpaid.

FETERITA - Similar to Kaffir corn in habit, but grows taller and makes a larger head. No seed of any kind has ever sprung so suddenly in such popular favor. 1 lb., 25c; postpaid. 


\section{Millet}

For hay sow 1 bushel per acre, and cut while in hloom before seed hardens. Sow from April 15th to end of July.

TENNESSEE GOLDEN-Produces more abundantly nutritious hay than any other. Produces a fine crop of hay in six to eight weeks' time, and on good land yieids two to two and a half tons per acre. Two crops can be seeded and grown during the summer on the same land. 1 lb., 25c; postpaid.

WESTERN GOLDEN-Similar to Tennessee, but does not produce as much hay or as large seed heads. 1 lb., 20c; postpaid.

HUNGARIAN-For grood low grounds or rich soil this makes even more valuable crop than the Tennessee Millet. It is considered equal in nutritious qualities to Timothy Hay. 1 lb., 25c; postpaid.

JAPANESE BARNYARD-Will produce three to five tons fodder if sown early. Sometimes called Billion Dollar Grass. This is a forage plant of great value, growing in moist any soil. It is relished by all classes of stock. $1 \mathrm{lb}$., 25c; postpaid.

PEARL OR CAT TAIL-Is fine for dairy cows. Makes a continuous cutting forage either green or hay. Sow 5 pounds per acre in drills three feet apart for best results. After being cut it will stool out enormously, becoming thicker; makes a rapid growth and will afford three or four cuttings during the season. It should not be sown until about May. 1 lb., 25c; postpaid.

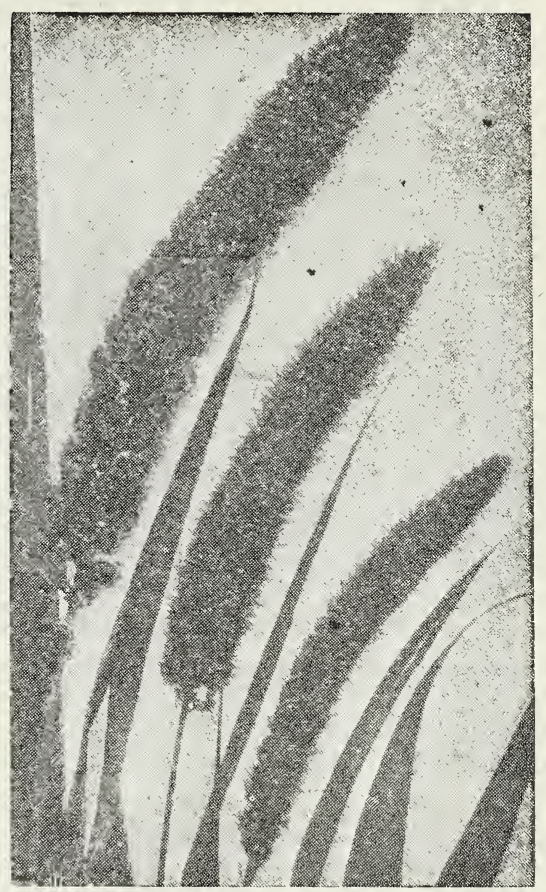

THE MILLETS

\section{Cotton Seed}

We have listed only such popular varieties as are in demand. We are in constant touch with growers of best pedigreed seed, so can supply any standard variety not listed. Write us for prices in large quantities. See price list herewith.

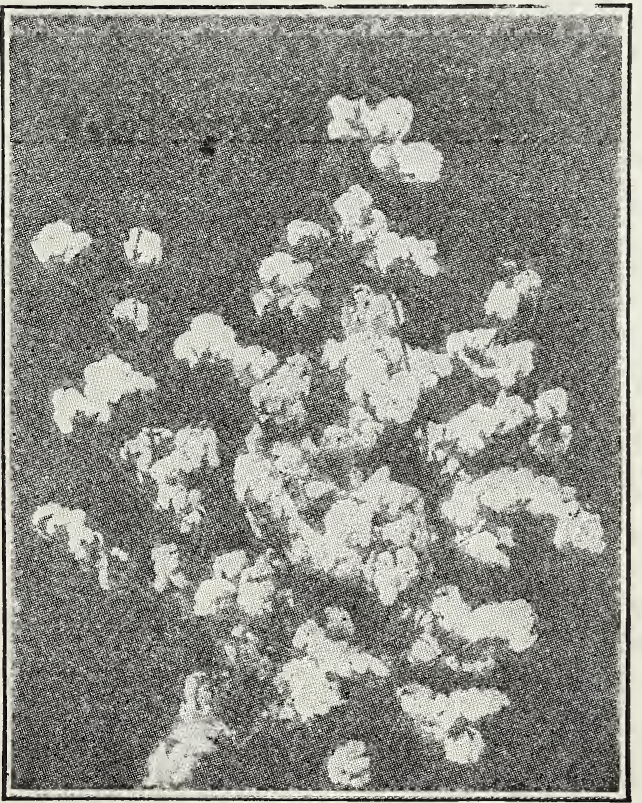

WANNAMAKER-CLEVELAND
WANNAMAKER-CLEVELAND-Since its introduction this cotton has been very generally grown throughout the Cotton States, and has unquestionably put itself in first p?ace with many of our most progressive cotton planters.

KING'S EARLY-One of the best kinds to plant in this section, either in bottom or hill land. Extra early and can be planted as late as July 1; will mature good crop.

WEBBER 49-Unquestionably this has proven to be the best of the early maturing long staples yet produced, and sume of the large Delta planters have become rich growing this variety.

HALF AND HALF-So named because it yields nearly half seed and half lint, very short staple, many growers favor this cotton while others are very much agains' it, owing to the short staple.

EARLY MEBANE TRICMPH-Is a tough-fibre cotton of medium staple; something between the ordinary short varieties and long staples.

EXTRA EARLY EXPRESS-It is good for the boll weevil sections on account of its earliness. It is a remarkably healthy variety, very resistant to disease affecting the Cotton. 


\section{Miscellanous Farm Seeds}

\section{Seed Oats}

Sow two bushels per acre in February or March, using $100 \mathrm{lbs}$. Nitrate of Soda in April. It will increase the crop.

EARLY BURT-Quick growing, most prolific and surest cropper of Spring Oat.

RED RUST PROOF-Does well on any good land, and is very productive.

\section{Buckwheat}

Sow in April to June, one bushel per acre broadcast.

JAPANESE-1 lb., 25c; postpaid.

SILVER HULL-1 lb., 25c; postpaid.

\section{Broom Corn}

Six pounds per acre when drilled in rows three feet apart.

IMPROVED EVERGREEN-1 lb., 25c; postpaid. OKLAHOMA DWARF-1 lb., 25c; postpaid.

\section{Sunflower}

RUSSIAN SUNFLOWER-Plant in March to May, $6 \mathrm{lbs}$. to acre in rows $3 \frac{1}{2}$ feet apart. $1 \mathrm{lb} ., 25 \mathrm{c}$; postpaid.

\section{Rape}

DWARF ESSEX RAPE-Sow broadcast $6 \mathrm{lbs}$. per acre, in drills two pounds per acre any-

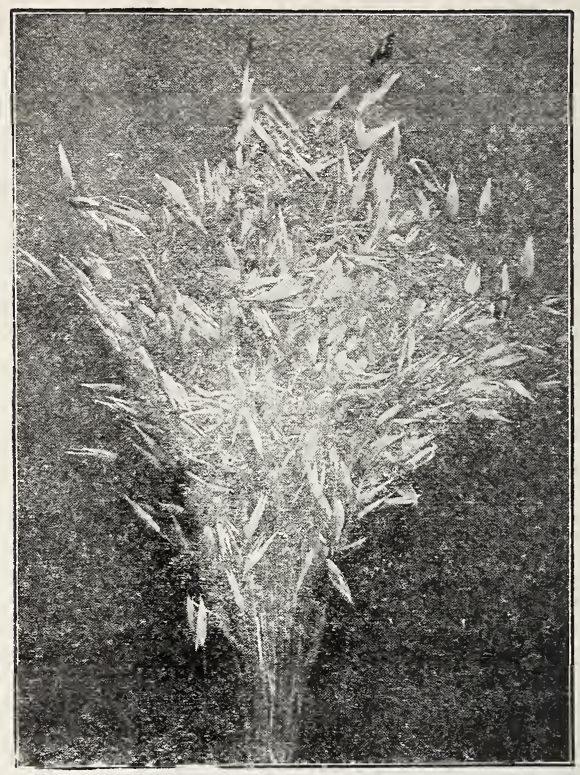

RED RUST PROOF OATS

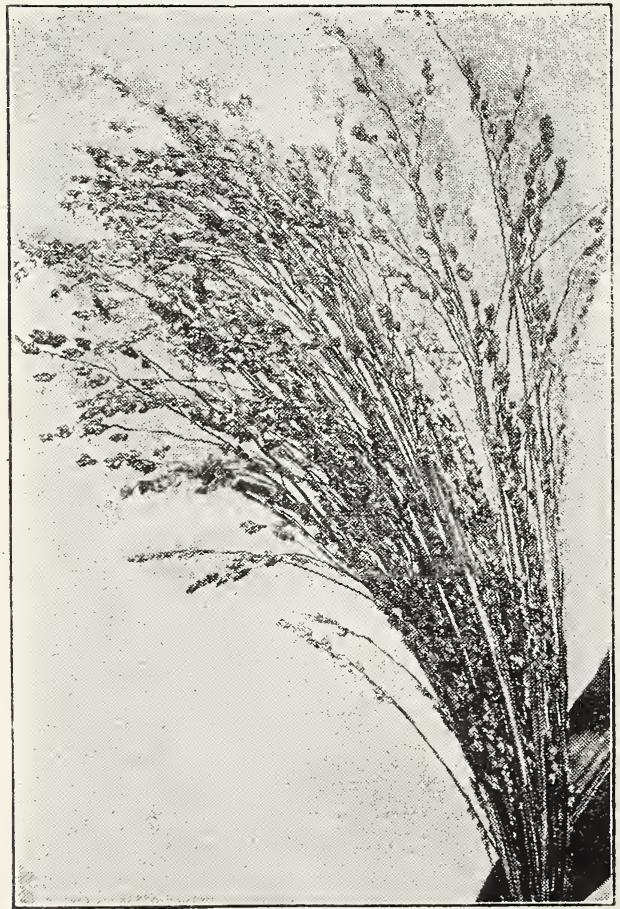

BROOM CORN time in Spring or Summer. Sown early in Fall will stand a moderate Winter. Excellent hog and sheep pasture. Served on table as greens, is very delicious. $1 \mathrm{lb}, 25 \mathrm{2}$; postpaid.

\section{Teosinte}

TEOSINTE-Resembles corn, but leaves larger and sap is sweeter. Sow in May or June, in drills $3 \frac{1}{2}$ ft. apart, 2 lbs. per acre. 11b., 75c; postpaid.

\section{Field or Cow Peas}

We can supply in season any of the following varieties:

WHIPPOORWILL or SPECKLED-A great favorite on account of its early maturity.

UNKNOWN or WONDERFUL-Especially valuable on account of the great growth of the vines.

BLACK-The vines grow very long. Large, latevining variety.

RED RIPPER-Makes an abundance of hay. One of the most prolific varieties.

CLAY - Very similar to the Unknown, but earlier; vigorous growth, very popular.

MIXED-Grows thicker than separate varieties; producing better crop of vines and forage.

1 lb., 25c; postpaid.

\section{Chufus or Earth Almonds}

Plant in April or May, 1 peck per acre, rows three feet apart, 8 to 10 inches apart in rows. $1 \mathrm{lb}, 30 \mathrm{c}$; postpaid.

For larger quantities see Price List herewith. 


\section{Velvet Beans}

A producer of the greatest amount of green stuff ever made on an acre of ground. Will put more nitrogen into your ground than any other legume. Drill 15 lbs. per acre, or $1 \mathrm{bu}$. broadcast. Hay of poor quality as its greatest value lies in bringing up poor lands.

EARLY SPECKLED - Sometimes called "90 Day." 1 lb., 25c; postpaid.

OSCEOLA-Free from stinging fuzz on the pods. $1 \mathrm{lb} ., 30 \mathrm{c}$; postpaid.

\section{Soy Beans}

One of the best summer forage crops and a splendid soil improver. For crop of beans, plant in drills three feet apart, $1 / 2$ bushel per acre.

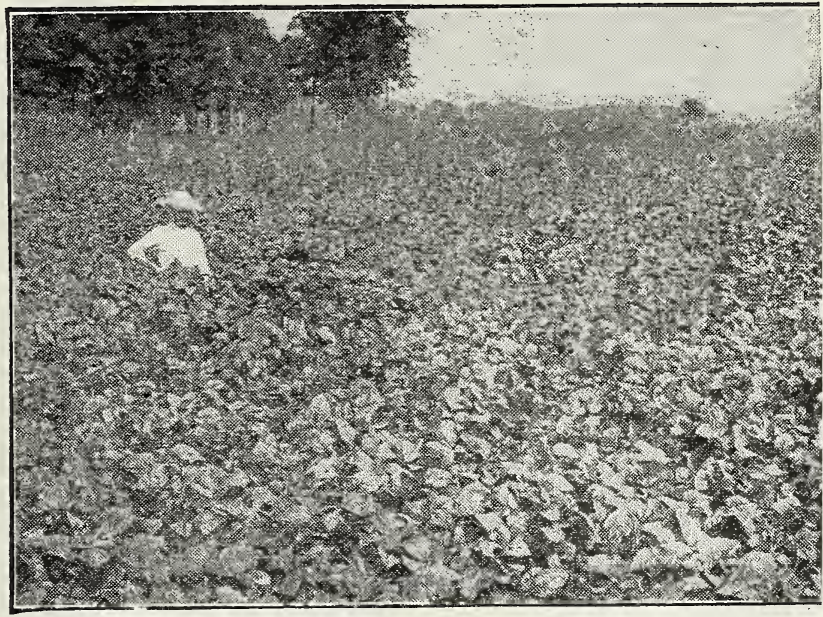

VELVET BEANS

CROWDER-Fine for table use, prolific, and sweet. $1 \mathrm{lb}$., 35c; postpaid.

CANADA FIELD PEAS-Sow 11/2 to 2 bushels per acre, or if with oats, 1 bushel of each. 1 lb., 40c; postpaid.

\section{Field Beans}

WHITE NAVY - Plant in June or July, rows three feet apart, dropping 2 to 3 together a foot apart in the rows. $1 \mathrm{lb} ., 50 \mathrm{c}$; postpaid.

WHITE MARROW-Plant same as White Navy. 1 lb., 60c; postpaid.

CASTOR BEANS-Plant and cultivate like corn. 1 lb., 40c; postpaid.

\section{Peanuts}

Prepare the ground well, laying it off in rows with a shovel plow; the rows should be three feet apart, and put two kernels to the hill, which are about one foot apart. Cultivate thoroughly and keep the land as level as possible. One and onehalf bushel of unshelled nuts will seed an acre. Plant in May or June.

SPANISH-In addition to their value for growing for nuts, these are very largely used in the South as a forage and fattening crop for hogs and other stock. They are early to mature, very productive, and in the far South, where they can be planted during March and April, two crops can be made in one year, the second crop being planted early in July, the tops making a hay crop and the nuts a grain crop. $1 \mathrm{lb}$., $25 c$; postpaid.

TENNESSEE RED-Erect busy habit, very productive. Especially adapted to the black, waxy land as well as the sandy soil. The nuts contain three large kernels in each and are enormously productive. $1 \mathrm{lb} ., 30 \mathrm{c}$; postpaid.

VIRGINIA WHITE-Best variety for commercial use. 1 lb., 30c; postpaid.

For Larger Quantities See Price List Herewith. 


\section{Flower Seed}

All Prices Postpaid.

ASTERS, Superb Mixed-A mixture of best varieties. 1 pkt., $10 \mathrm{c}$.

ASTERS, Traffaut's Perfection-Produce on long stems, large brilliantly colored bell-shaped flowers. Pkt., 10c.

BALSAM, Double Mixed-Fine for bedding. Brilliant colored flowers. Grows 2 feet high. Pkt. 5c.

CALENDULA, Meteor-The popular Pot Marigold. Large double flowers. Pkt., 10c.

CALLIOPSIS-Attractive, showy flowers in variations of yellow and brown. Height 2 feet. Pkt., $5 c$.

CANDYTUFT-Flowers produced in clusters and a wonderful variety of colors. Fine as cut flowers. Pkt., 5c.

CARNATION, Mixed-Flowers are very fragrant and of many colors. Sow in boxes and plant out in Spring when frost is past. Pkt., 10c.

CATCHFLY, Mixed-A very showy, hardy annual, bearing in quantity, heads of beautiful pink, white and red flowers. Pkt., 10c. CENTRANTHUS-Pkt., 5c.

CHRYSANTHEMUM, Mixed - Showy and effective family of plants of varied character grown extensively for cut flowers. Pkt., 10c.

CORNFLOWER-Known as Ragged Sailor or Bachelor's Button. Pkt., 5c.

Cosmos, Fine Mixed-This beautiful annual is one of our most showy and useful garden plants. Pkt., 5c.

CRIMSON FLAX-One of the most brilliantly colored of Summer annuals. Pkt. 5c

CYPRESS VINE, MixedCannot be excelled for _training on trellis. Pkt., 5c.

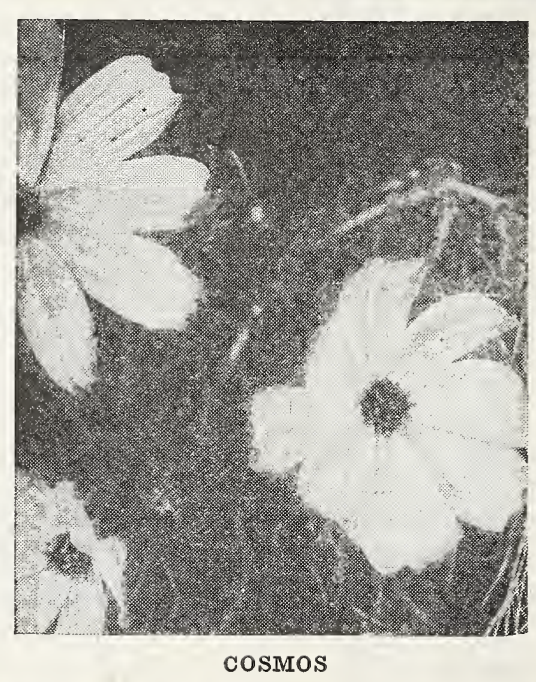

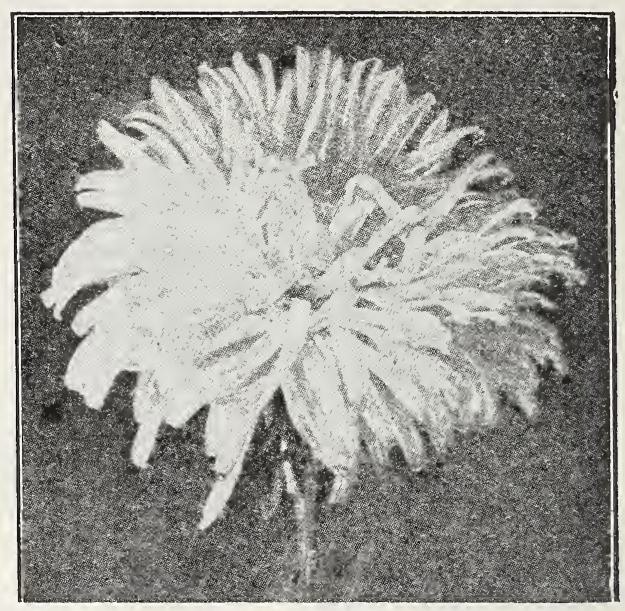

ASTER

DAHLIA, Single Mixed Plant in shallow boxes in March. When frost is over plant in bed or border in garden. Pkt., 10c.

EVENING PRIMROSE, Mixed-Pkt., 10c.

ESCHSCHOLTZIA CALIF. POPPY, Mixed-A bright, free blooming plant of low spreading growth with finely cut silvery foliage. Sow the seed where the plants are to remain. Pkt., 10c.

FOUR O'CLOCK, MixedAnother old-fashioned flower of bushy habit, bearing countless flowers of white, yellow, crimson and violet. Pkt., 5c.

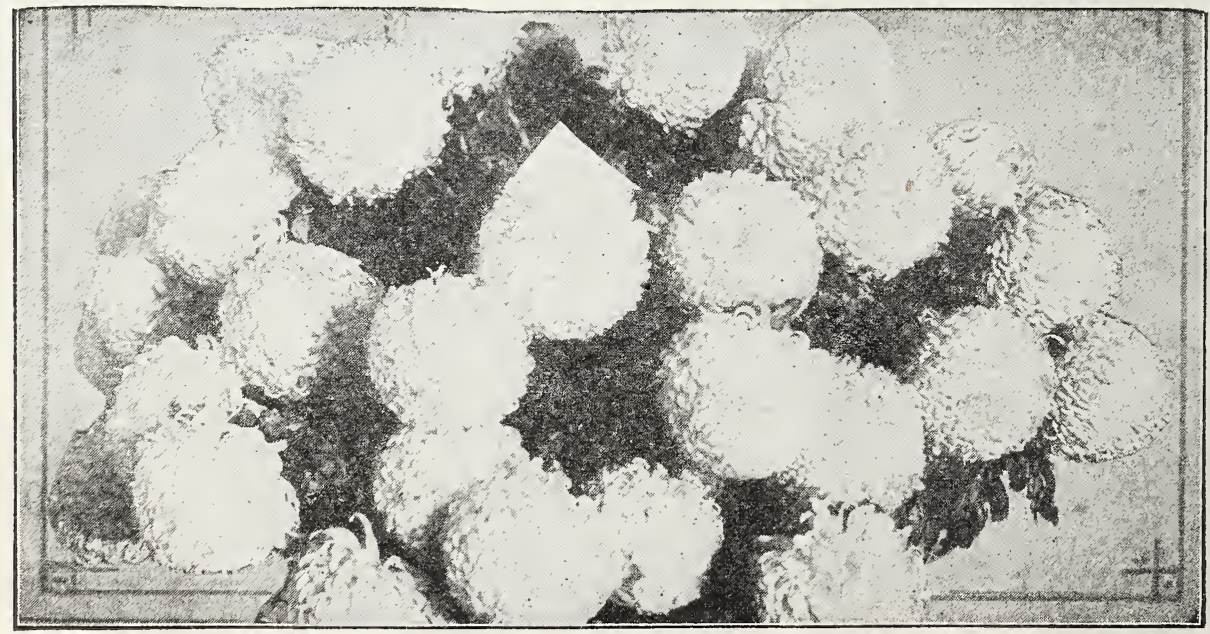

CHRYSANTHEMOMS 


\section{FLOWER SEEDS-Continued}

HELICHRYSUM (Strawflower) - A grand mixture including the best varieties. Pkt., 10c.

HYACINTH BEAN-The most popular Jack Bean. Produces profuse foliage for trellis. Pkt., $10 \mathrm{c}$.

HOLLYHOCKS (Annuals) - This variety blooms first year from seed. If sown in open ground in May will flower in August. Pkt., 10c.

LARKSPUR-Well known annual of great beauty. These handsome flowers are very effective in borders and planted among shrubs. Pkt., 10c.

LOVE-IN-A-MIST, Mixed-A compact, free flowering plant with finely cut foliage. Blue and white mixed. Pkt., 10c.

MARIGOLD-In late summer, when many bedding plants are past their prime, Marigolds afford a wealth of color. These are old favorites. The present varieties have been greatly improved in size and beauty of flowers. Pkt., $10 \mathrm{c}$.

MIGNONETTE-There is no flower equal to the Mignonette in delicacy of fragrance. Valuable for both bedding and pot culture. Pkt., $10 \mathrm{c}$.

MORNING GLORY-For covering trellises and fences no climber is more popular than the Morning Glory.

MOON FLOWER - Beautiful, rapid annual climber. Will reach a height of 20 to 30 feet in a single season. Foliage large, dense and luxurious. Pkt., 10c.

NASTURTIUM - Few plants are so useful or rich in color. They surpass the Geranium in brilliancy of color and profusion of bloom. One ounce will plant a bed twenty feet in diameter.

-Dwarf Mixed-Pkt., 10c ; 1 oz., 15c; 1/4 lb., 30c; 1 lb., $\$ 1$; 15c; $1 / 4$ lb., 30c; 1 lb., $\$ 1.00$; postpaid.

-Tall Mixed-Pkt., 10c; 1 oz.,

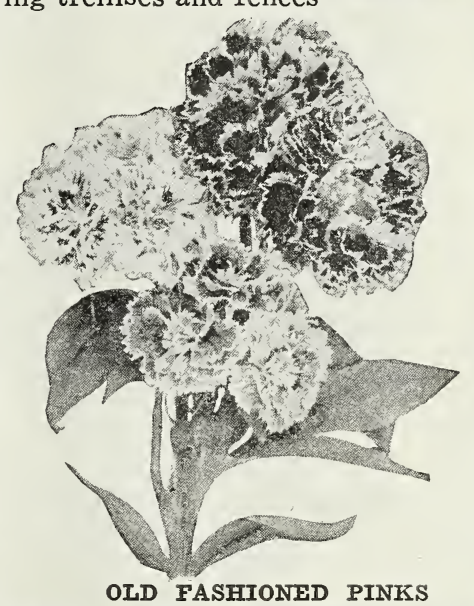

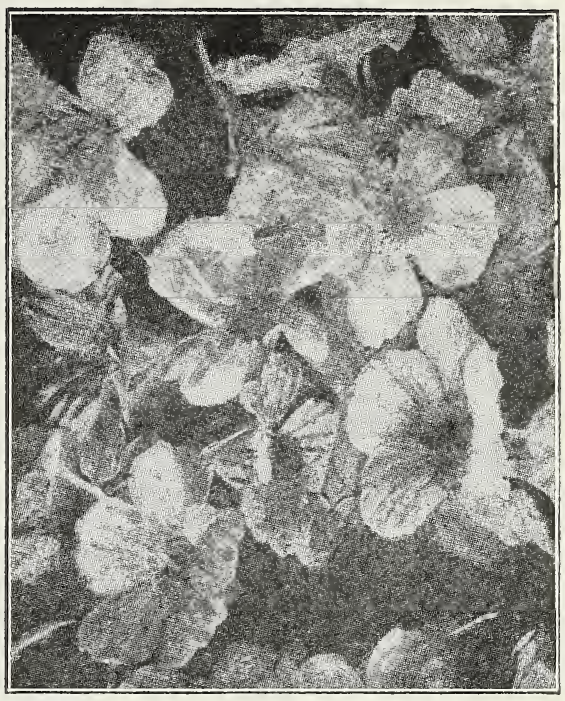

NASTURTIUMS

15c; 1/4 lb., 30c; 1 lb., $\$ 1.00$; postpaid.

- Lobbs Mixed (6 ft.)-Pkt., 10c, 1 oz., 15c; 1/4 lb., 40c; 1 lb., \$1.25; postpaid.

PANSIES - French Mixed Embraces the best shades and colors. These lovely flowers are everybody's favorites. Pkt., $10 \mathrm{c}$.

PETUNIA, Single Mixed-For freedom of bloom, variety of color and effectiveness, these have no equals. Particularly showy in beds or masses. Commence flowering early and continue throughout the summer. Very fragrant. Pkt. $10 \mathrm{c}$.

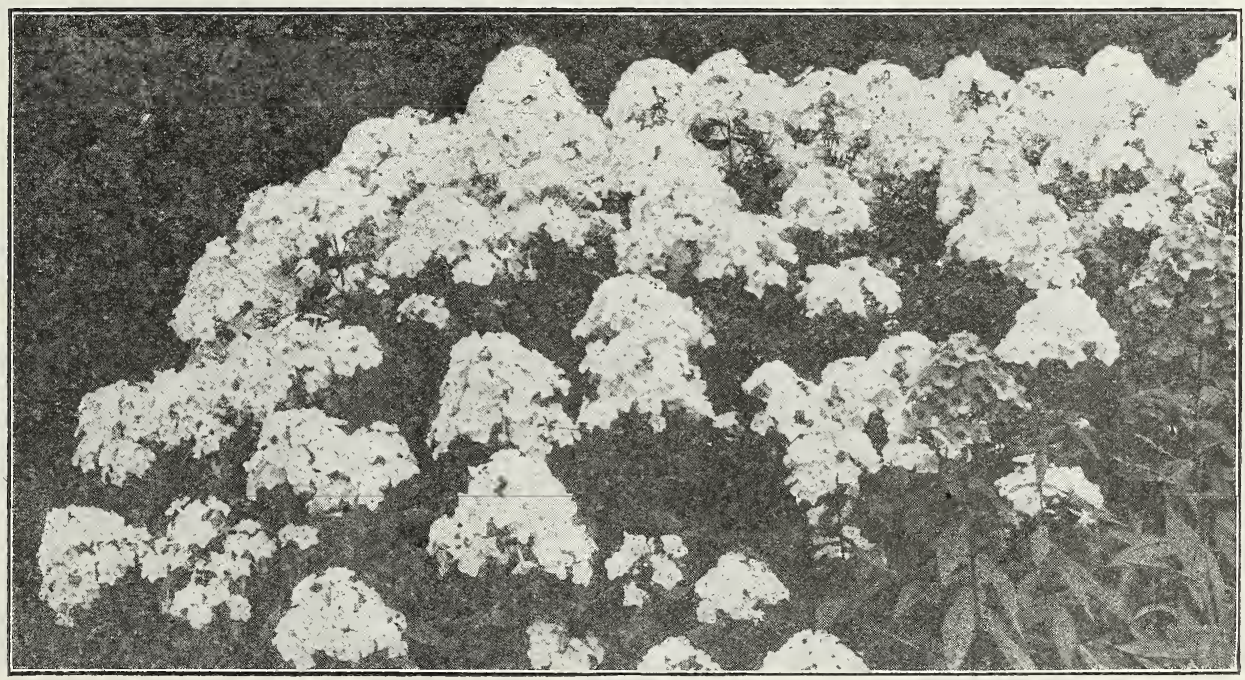

PHLOX 


\section{FLOWER SEEDS-Continued}

PHLOX DRUMMONDI Mixed-Seed should be sown in the ground when all danger of frost is past, and in a few weeks the beds are a blaze of glory. Few flowers give more satisfaction. The colors range from the purest white to the deepest crimson. Pkt., 10c.

PINKS-A popular annual variety known nearly to all. Well adapted for beds and borders; delightfully refreshing, fragrant spicy odor.

-China Double Mixed-Pkt., 10c.

-Japan Mixed-Pkt., 10c.

POPPY-Plants are of quick growth and produce a wealth of gorgeous blossoms. Plant the seed in succession two weeks apart for a continuous bloom all summer.

-Danebrog-Brilliant scarlet flowers, with a silvery spot in each petal. Pkt., 10c.

-Carnation Flowered-Double, large size flowers of all shades. Pkt., 10c.

-Mixed-A mixture of the best varieties. Pkt., 10c.

PORTULACCA, Mixed-The popular Moss Rose. Is of a low-spreading growth, bearing a profusion of very brilliant colored flowers. Will grow and bloom in a hot, dry situation where most plants would die. Pkt., $10 \mathrm{c}$.

\section{SCABIOSA or MOURNING} BRIDE-(2 $1 / 2$ feet.) Quite hardy plants, flowering freely in cool locations or during late summer and fall months Pkt., 5c.

SNAP DRAGON, Mixed-For gorgeous coloring few flowers can match Snapdragon. They are easily raised from seed in a good rich sunny bed. Pkt., 10c.

SUNFLOWER, CALIFORNIA DOUBLE-They are hardy annuals of easiest culture, simply requiring that seed be sown in rich soil early in spring. Pkt., 10c.
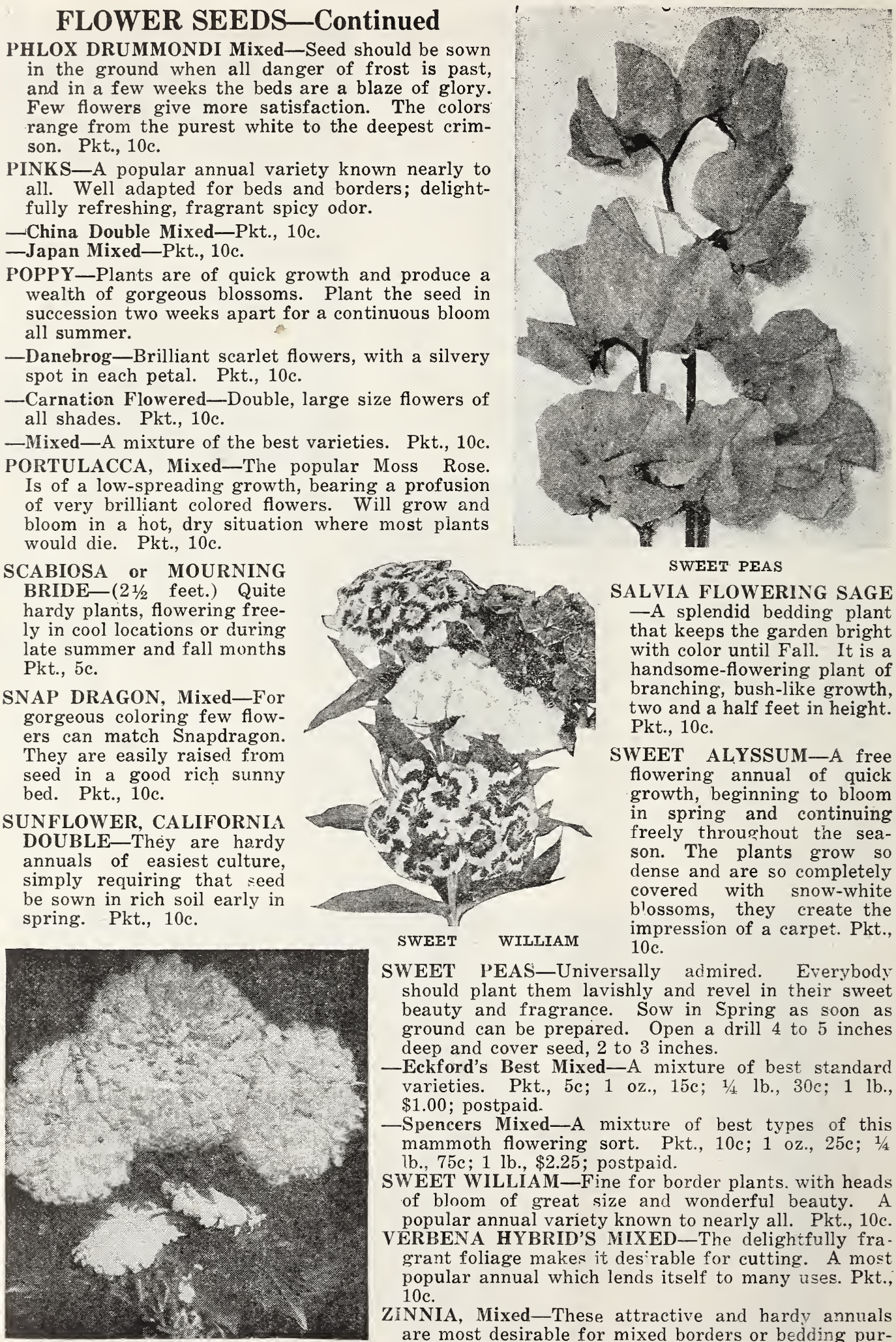

SWEET PEAS

SALVIA FLOWERING SAGE -A splendid bedding plant that keeps the garden bright with color until Fall. It is a handsome-flowering plant of branching, bush-like growth, two and a half feet in height. Pkt., 10c.

SWEET ALYSSUM-A free flowering annual of quick growth, beginning to bloom in spring and continuing freely throughout the season. The plants grow so dense and are so completely covered with snow-white blossoms, they create the impression of a carpet. Pkt., $10 \mathrm{c}$.

SWEET PEAS-Universally admired. Everybody should plant them lavishly and revel in their sweet beauty and fragrance. Sow in Spring as soon as ground can be prepared. Open a drill 4 to 5 inches deep and cover seed, 2 to 3 inches.

-Eckford's Best Mixed-A mixture of best standard varieties. Pkt., 5c; 1 oz., $15 \mathrm{c} ; 1 / 4 \mathrm{lb} ., 30 \mathrm{c} ; 1 \mathrm{lb}$, $\$ 1.00$; postpaid.

-Spencers Mixed-A mixture of best types of this mammoth flowering sort. Pkt., 10c; 1 oz., 25c; 1/4 lb., $75 \mathrm{c} ; 1$ lb., $\$ 2.25$; postpaid.

SWEET WILLIAM-Fine for border plants. with heads of bloom of great size and wonderful beauty. A popular annual variety known to nearly all. Pkt., 10c.

VERBENA HYBRID'S MIXED-The delightfully fragrant foliage makes it des'rable for cutting. A most popular annual which lends itself to many uses. Pkt., $10 \mathrm{c}$.

ZINNIA, Mixed-These attractive and hardy annuals are most desirable for mixed borders or bedding purZINNIAS poses. Pkt., 10c. 


\section{Summer Flowering Bulbs \\ DAHLIAS}

The Dahlia is one of the showiest of all autumn flowers. Commencing to flower in July, they are a perfect blaze of bloom until stopped by frost. Will grow in most any kind of soil.
Double Pink
Double Yellow
Double White
Double Purple
Double Scarlet
Double Striped

Price, any shade, each $35 \mathrm{c}$; doz, $\$ 3.25$; parcel post paid. By express, each $30 \mathrm{c}$; dozen, $\$ 3.00$.

\section{CALADIUM BULBS}

CALADIUM ESCULENTUM (Elephant's Ears)Effective as a single plant on a lawn or in groups; also very useful for decorative effects near streams or pond. To obtain the best results they should be planted on rich ground and where they will have an abundance of water.

Small Bulbs-By parcel post, each, 20c; doz., \$1.50. By express, not prepaid, each $15 \mathrm{c}$; doz., \$1.25.

Large Bulbs-By parcel post, each, 30c; doz., \$2.75. By express, not prepaid, each $25 \mathrm{c}$; doz., $\$ 2.50$.

Extra Large Bulbs-By parcel post, each $60 \mathrm{c} ; 3$ for $\$ 1.50$. By express, not prepaid, each, $50 \mathrm{c}$, 3 for $\$ 1.25$.

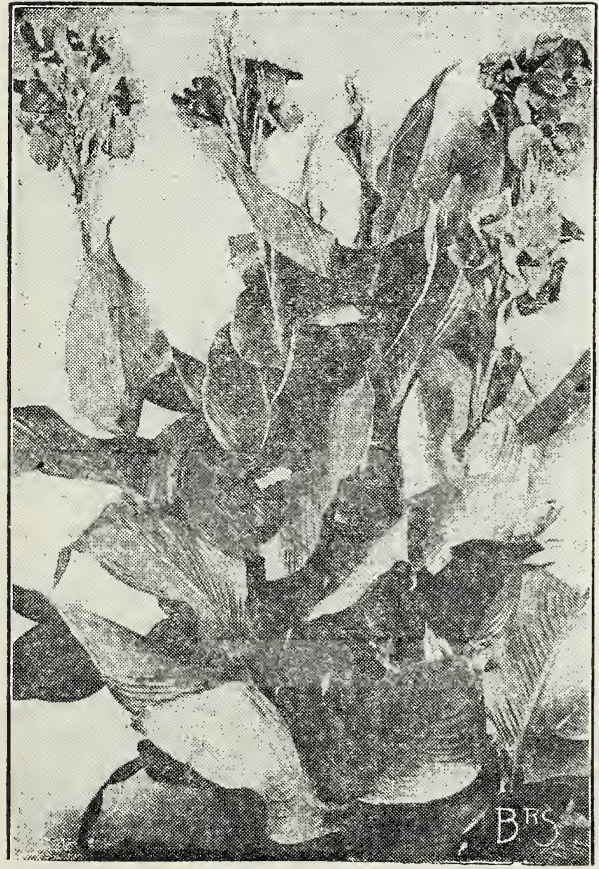

CANNA PLANTS

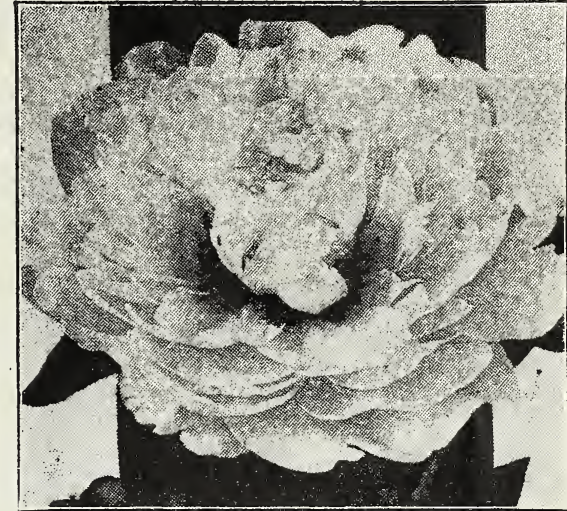

PEONIES

\section{TUBEROSE}

DOUBLE PEARL-A Beautiful, fragrant flower, that is easily raised from the bulb, planted in the spring. Doz., 85c; postpaid. By express, doz., 75c; 100 for $\$ 5.50$.

\section{MADERIA VINE}

A beautiful, rapid growing climber, bearing fragrant white flowers. Each, 10c; doz., \$1.00; parcel post paid.

\section{CINNAMON VINE}

Hardy climber, of a delicious cinnamon fragrance. Each, 10c; doz., \$1.00, parcel post paid.

DAHLIA

\section{PEONIES}

They have become indispensable in every garden. They are all hardy and admirably suited to our Southern climate, growing in almost all situations, and even flourishing under shade trees.

Red, Pink, White-Each, 45c; parcel post paid. By express, each $35 \mathrm{c}$; doz., $\$ 3.00$.

\section{GLADIOLUS}

This flower is one of the most wonderful, and withal one of the most satisfactory that can be grown. Wonderful on account of its wealth of color, embracing most. of the hues of the rainbow. Planted during the very ear'y spring they will produce handsome cut flowers that will last for a week or more. Hybrid Fine Mixed-By parcel post, doz., 60c; by express, not prepaid, doz, 50e.

Childsii-Mixed-By narcel post, doz, 70c; by express, nct prepaid. doz., $60 \mathrm{c}$

\section{CANNAS}

Cannas have been used as bedding plants as long as one can remember, and the old forms are familiar to everyone. A fine fol age plant: a rapid grower, producing large trusses of beautiful flowers from early summer to late in the autumn.

Red, Yellow, White, Yellow and Red, Red with Golden Border.

Price. Bulbs, each $20 \mathrm{c} ; 12$ for $\$ 1.75$, parcel post paid. By express, not prepaid, each $15 \mathrm{c} ; 12$ for $\$ 1.50$. 


\section{INSECTICIDES}

Insecticides Cannot Be Sent Through Mail Except Where Noted.) SLUG SHOT, Hammond's-Non- poisonous; a
splendid pow.der for general use. $1 \mathrm{lb}, 30 \mathrm{c}$; 5 lbs., 75c; 10 lbs., \$1.25, postpaid. By freight or express, $1 \mathrm{lb} ., 20 \mathrm{c} ; 5 \mathrm{lbs} ., 60 \mathrm{c} ; 10$ lbs., $\$ 1.00$.

ARSENATE OF CALCIUM DRY POWDERED-It has relatively the quick killing properties of Paris Green, but adheres to leaf for a longer time. $1 \mathrm{lb.,} 55 \mathrm{c}$; $5 \mathrm{lbs} ., \$ 2.25 ; 10 \mathrm{lbs}$., $\$ 4.50 ; 25$ lbs., $\$ 10.50 ; 50$ lbs., $\$ 19.50 ; 100$ lbs., $\$ 38.00$.

ARSENATE OF LEAD-Does not burn foliage, kills every insect that eats it and is superior in every way to Paris Green. $1 \mathrm{lb}$., 65 ; 5 lbs., $\$ 2.75 ; 10$ lbs., $\$ 5.00 ; 25$ lbs., $\$ 12.00 ; 100$ lbs., $\$ 42.00$.

PARIS GREEN-1/4 lb., 25c; $1 / 2$ lb., 40c; $1 \mathrm{lb}$., $70 \mathrm{c} ; 5$ lbs., $\$ 3.00$.

LIME SULPHUR DRY POWDERED-The winter spray when trees are dormant. Controls scale and other pests which attack the bark. 1 lb., 35c; 5 lbs., $\$ 1.50 ; 10$ lbs., $\$ 2.50$; 25 lbs., $\$ 5.00$.

BORDO-ARSENATE, DRY POWDERED-An insecticide and fungicide combined. Controls tomato wilt to a certain degree. $1 \mathrm{lb}$., $60 \mathrm{c}$; 5 lbs., $\$ 2.50 ; 10$ lbs., $\$ 4.75$.

BORDEAUX MIXTURE, DRY-Controls fungus diseases. $1 \mathrm{lb}$., $45 \mathrm{c} ; 5$ lbs., $\$ 2.00 ; 10$ lbs., $\$ 3.50$.
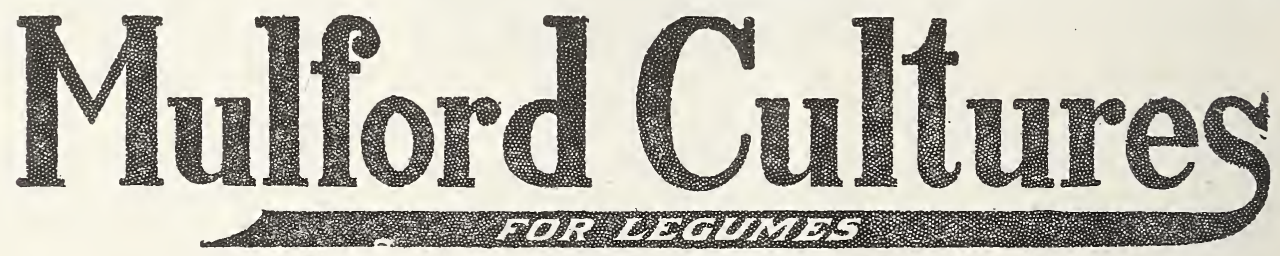

-TO INOCULATE YOUR-

Half-bushel round, 1 dozen ........... \$3.00

One-bushel round, 1 dozen $\ldots \ldots \ldots \ldots \ldots \$ 3.00$

YROX-A fungicide and insecticide combined.

1 lb., 50c; 5 lbs., $\$ 1.75 ; 10$ lbs., $\$ 3.00$.

OBACCO DUST-Valuable for killing lice on lbs., $\$ 1.75$.

"SEND FOR BOOKLET ON SPRAYING"

\section{Spray Pumps and Seeders.}

HAND ATOMIZER-Holds one quart liquid. cheap, serviceable spray. Tin, 60c; postpaid

HE RITTENHOUSE SEEDER-The popular hand broadcast seeder. Does good work at a cheap price. $\$ 2.00$ each. $\$ 2.20$, each postpaid. TIN HORN SEEDER-Simple and easy to operate. Will sow any fine seed. $75 \mathrm{c}$ each, postpaid.

WHEELBARROW SEEDERS-Best for sowing grass or any other light seeds. Does perfect work. $16 \mathrm{ft}$. hopper. $\$ 12.50$ each.

CAHOON BROADCAST SEEDER-Built entirely of steel and will last for years. The best broadcaster made. $\$ 4.75$ each. Postpaid, $\$ 5.00$ each.

MOLE TRAPS- $\$ 1.00$ each.

\section{BASKETS}

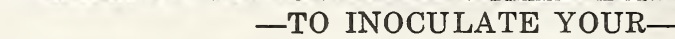

ALFALFA, CLOVERS, COW PEAS, SOY BEANS, VETCHES and all other LEGUME CROPS SMALL COST LARGE RETURNS EASY TO USE NO LABOR EXPENSE

Mulford Cultures contain pure, tested strains of active, vigorous nitrogen-fixing bacteria for inoculating seeds of legumes or soil. Price: 1 a cre size, $\$ 1.50 ; 5$-acre size, $\$ 5.00$.

\section{Ullathorne's Inoculating Bacteria}

THE GUARANTEED LEGUME INOCULATOR GROWN DIRECT FROM NODULES HIGHEST POSSIBLE VIRILITY

Increases the Yield-Enriches the Soil-Hastens Maturity_Improves the Feeding Value-Saves Fertilizer Bills-Easy to Apply-Full Directions in Every Package.

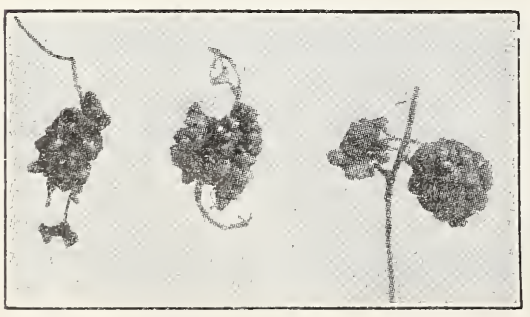

NITROGEN NODULES

Bulletin No. 53, South Carolina Experiment Station says: "Inoculation is not a cure all, but its proper use will send the farmer farther forward in three years than it has been possible for him to go without it in a generation."

Ullathorne's Inoculating Bacteria are not cheap cultures. They may be cheaper in price than some but in price only. The price is still consistent with high quality. They cannot be made better even if ten times the prices were offered. Every package is fully guaranteed. Prepared for Alfalfa, Red Clover, Cow Peas, Soy Beans, etc. 1-acre size, 75c; 2 -acre size, $\$ 1.40 ; 6$-acre size, $\$ 3.00$, postage paid. 


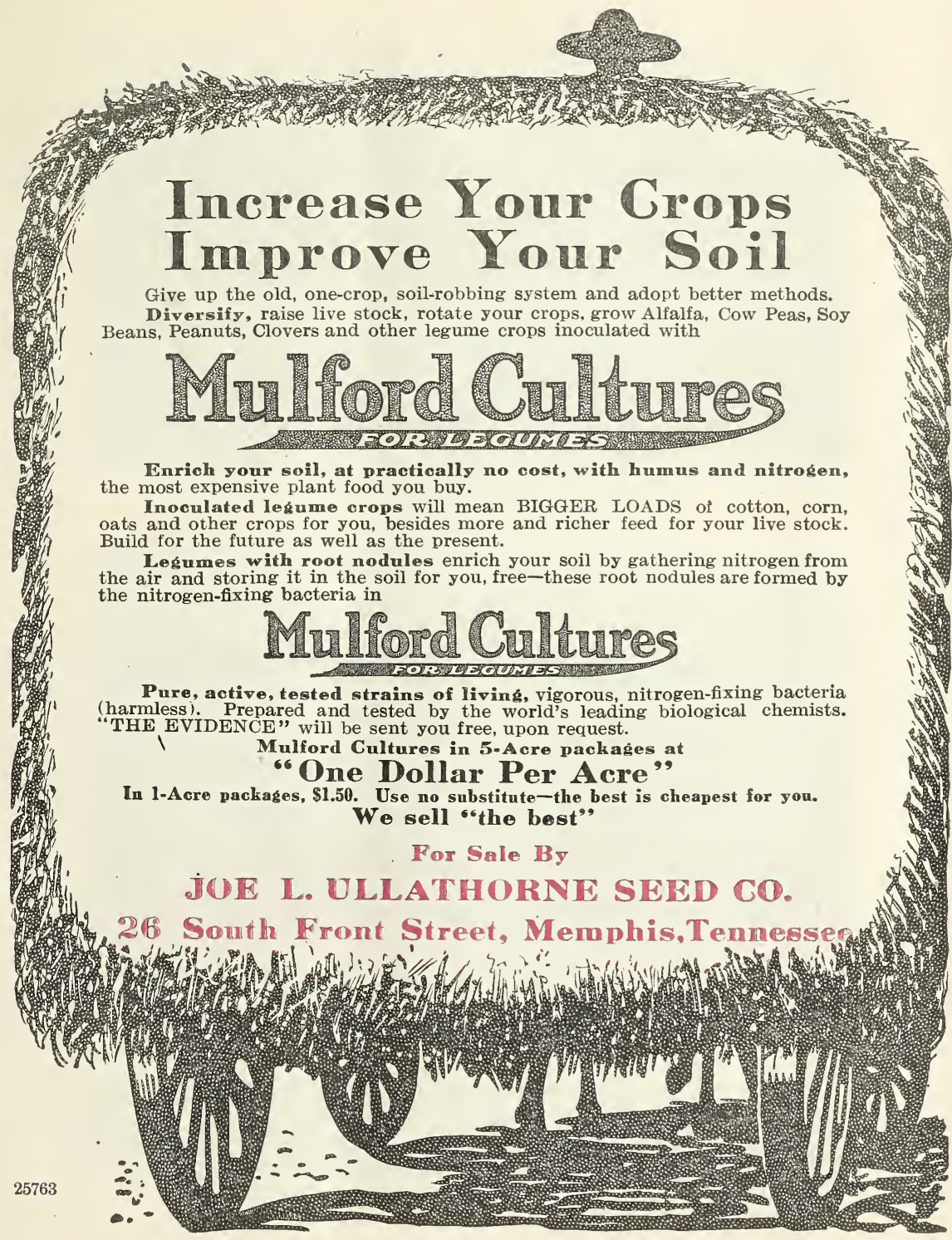




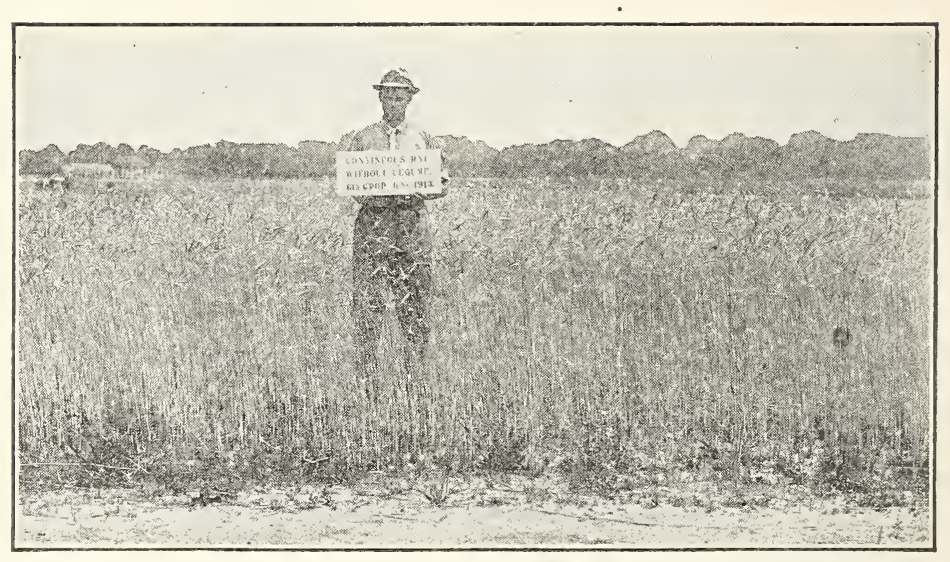

Continuous Rye. No nitrogen supplied.

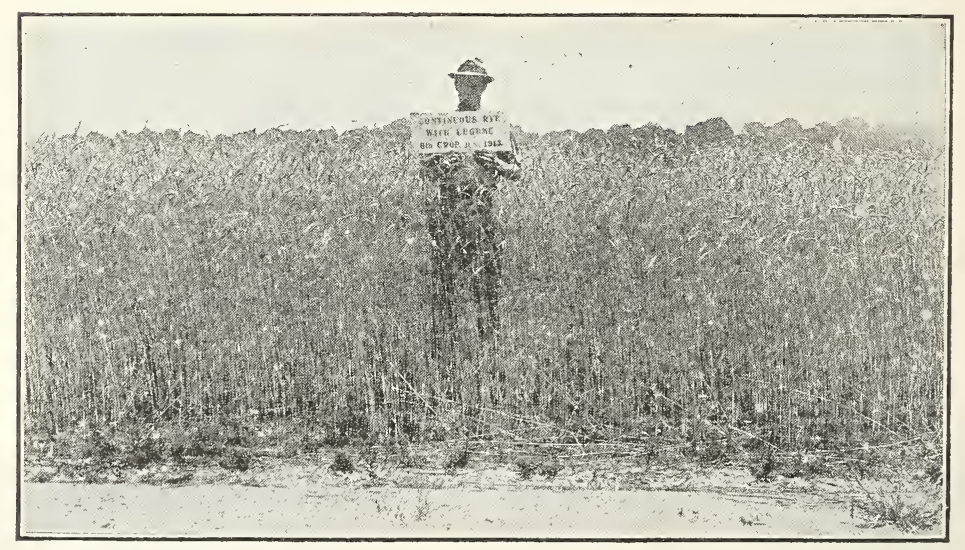

Continuous Rye. Nitrogen supplied by leguminous crop grown each year after harvesting the Rye.

The above illustrations are from a report of the New Jersey Agricultural College Experiment Station. Similar results were obtained with wheat. The yield of rye grain was nearly one-fourth greater, and the yield of wheat grain was more than double on the plots where legumes were grown. The experiment clearly shows that by growing legumes it is possible to increase the yield of succeeding non-legume crops, both in grain and in straw, and therefore, in the amount of nitrogen accumulated. 


\section{The Joe. L. Ullathorne SEED MERCHANTS 26 South Front St. MEMPHIS,}

The prices noted are for immediate order and shipment. As prices change from tir two weeks. Should you order from us and prices have changed, we will give you t| prices advance, we will fill your order at the very lowest market price.

OUR TERMS ARE NET. CASH WITH ORDER OR SIGHT DRAFT WITH

BUSH BEANS, (Green Pod)

Catalcgue Page No. 1

$\mathrm{Pk}$.

$\mathrm{Bu}$.

$\$ 2.40 \$ 8.50$
SEED CORN (Field)

Catalogue Page No. 17-20.

Pk. Bu.

U's Champion Ea. W. D.... $.90 \quad 3.00$

Ea. Red Valentine

- 



\section{The Joe. L. Ullathorne Seed Co. SEED MERCHANTS}

\section{South Front St. MEMPHIS, TENN.}

The prices noted are for immediate order and shipment. As prices change from time to time, we isoue a new list every two weeks. Shonld you order from us and prices have changed, we will give you the advantage of any drop. Should prices advance, we will fill your order at the very loweat market price.

OUR TERMS ARE NET. CASH WITH ORDER OR SIGHT DRAFT WITH BILL OF LADING ATTACHED

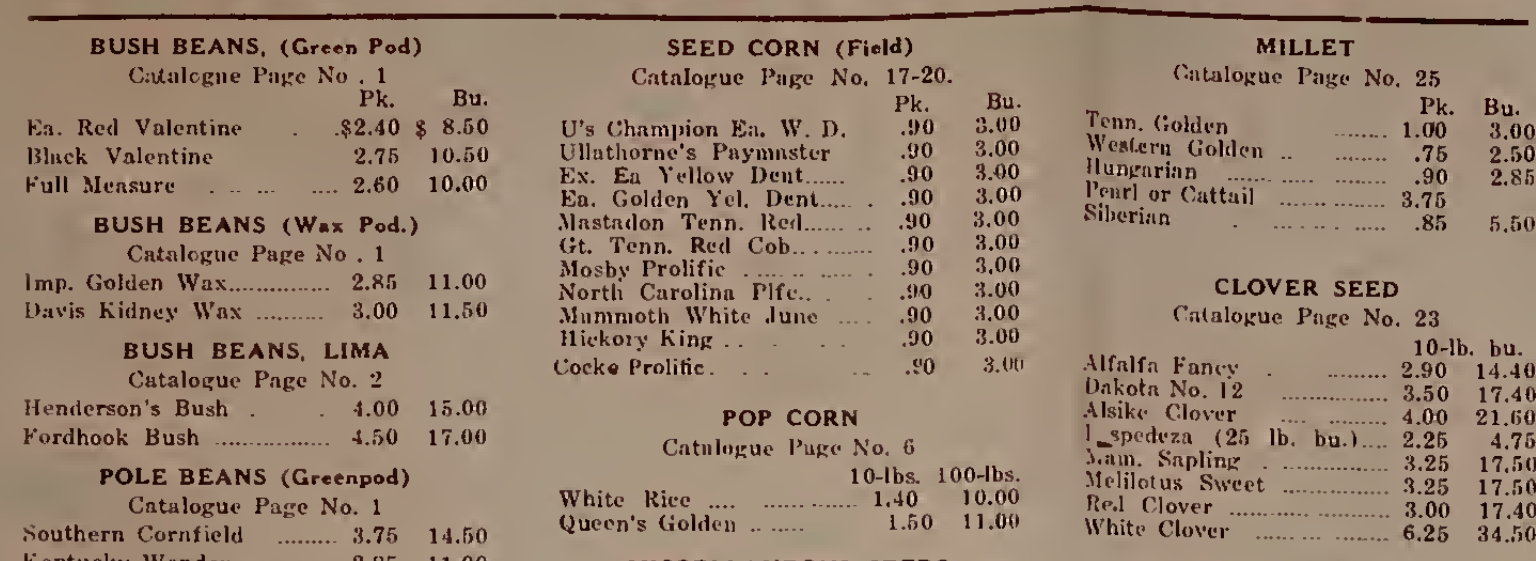

kentucky Wonder ........... $2.85 \quad 11.00$

St. Louis Perfuction ......... $4.00 \quad 15.00$

POLE BEANS, LIMA

Cintalogue Page No. 2

small Whits Butter........ $3.85 \quad 15.00$

large White Lima .......... $4.00 \quad 16.00$

GAROEN PEAS

Catalogue Page No. 11

Early Alaska .............. 2.50

07.50

First and Best ....... $2.75 \quad 8.00$

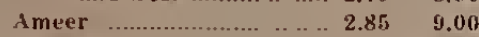

Alderman ......................... $3.75 \quad 10.50$

Telephone ….................... $3.90 \quad 12.00$

large Marrowfat .............. $2.00 \quad 7.00$

GARDEN CORN

Catalozuc Page No. 6

Stowell's Evergreen .......... 2.00

Country Gentleman ............. 2.00

Golden Bantam ................. 2.40

Adams Extre Exrly ........ 1.50

ddanis Large Early ............ 1.50

Howling Mob

$2.20 \quad 7.00$

\section{ONION SETS}

Catalogue Page 10.

$\begin{array}{lll}\text { White Silverskin } & \ldots \ldots . . & .75\end{array}$

Rod weathersfield 1.75

Yellow Danvers ............... .65 1.50

Yellow Potatoc .............. 1.75

White Multipliers ........... $1.75 \quad 5.00$

ked Shallots ................... .75 2.50

POTATOES (60.lb. Bu.)

Cataloguc Page No 16 .

6.50

6.50

6.50

5.50
5.50

7.00

\section{MISCELLANEOUS SEEDS}

Artichokes $(50 \mathrm{lb}, \mathrm{bu}) \quad \begin{aligned} & 1 \mathrm{k} k \mathrm{Bu} . \\ & \$ 1.25 \$ 4.00\end{aligned}$ Broom Corn. Mo.

Evergreen (46 lb. bu.).. $\quad . .1 .00 \quad 3.00$

Broom Corn. Okla.

Durnef (46 lb. bu.) .............. $1.00 \quad 3.25$

Buckwheat Jap (50 lb. bu) $1.15 \quad 4.00$

Buckwheat Silverlull ... $1.15 \quad 4.00$

Chuf as, Georgia ................ $2.00 \quad 6.5 \mathrm{n}$

Rrine, Dwf. Essex …......... $2.00 \quad 6.50$

Teosinte, 1 -lb. 80c; 10 lbs.......... 7.00

Chufas ............................... 2.00

SEEO OATS ( 32 lb. bu)

Critalogue Page No. 26

We sell nothing but receleaned stock.

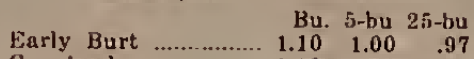

Ga. Appler …............... $1.100 \quad 1.10 \quad 1.00 \quad .97$

$\begin{array}{lrrr}\text { Red Kustproof ............ } & .90 & .90 & .97\end{array}$

COTTON SEED 33.lb.-bu.)

Catalogue Page No. 25

3-bu. 15-bu.

Clevelan. Bu.

Cleveland Big Boll ..........\$2100 \$ 1.75

Express No. $150 \ldots \ldots \ldots \ldots . . .2 .00 \quad 1.75$

Meb.une T'rimmp ................. 2.00 $1.7 \bar{i}^{2}$

Winnamaker Clevcland ....... $1.95 \quad 1.79$

Webber 4! ........................ $2.00 \quad 1.75$

GRASS SEEDS

Catalogue Pages No. 21-22

U's Mlixed Lawn 10-lb 100-lb.

U.

Shar Spot ..................... 4.25 42.00

$2.75 \quad 38.50$

l'er Hog. Mixture .............. $3.00 \quad 32.00$

Chicken Pasture .................. 2.00 $2.00 \quad 30.00$

Timothy ind Alsike.............. $2.25 \quad 18.00$

Orehard ...............

Ky. Blue Giass .................. $3.90 \quad 39.00$

Eng. Blue Grass ........... $2.00 \quad 33.00$

Italian Rye

Burmudu

Fancy Red Top (Herd)

Cancy Red Tlop (Herd)......

Canadian Bluc .................... $3.25 \quad 27.00$

$\begin{array}{lll}\text { Tall Mcadow Oat ................ } 5.00 & \$ 3.00 \\ \text { Timothy ........................... } & 1.50 & 11.00\end{array}$

Sudan Grass .............................. $1.50 \quad 11.00$
SORGHUM, KAFFIR CORN, ETC.

(So.lb.-bu.)

Catalogue Page No. 24

Early Amber .................. $.50 \quad 1.25$

Early Oranke ................................... $.55 \quad 1.25$

$\begin{array}{lllll}\text { Futerita } & . . & \ldots \ldots \ldots \ldots \ldots \ldots \ldots . . . & .60 & .60\end{array}$

lap. Honey Cane ....................... 70 2.50

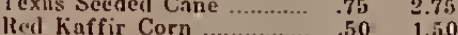

Red Ton Cane .............. $.50 \quad 1.50$

Yullow yilomaize ................ .85 1.50

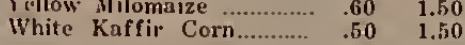

PEANUTS (22.lb, bu)

Catnlogue Page 27

Mam. White Virginia....... $1.10 \quad 3.75$

'Tenn. Lonk Red ................ $1.20 \quad 4.00$

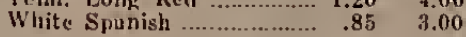

SOY \& VELVET BEANS (60lb.bu) Catulogue Page No. 27

Mam, Yullow Soy .............. .90 3.2!

I00 Day Spkld. Velvet........ $.70 \quad 2.50$

Oscrola Velvet . .............. $\quad .85 \quad 3.00$

STOCK PEAS (60 lb. bu)

Catalogue Pare No. 27

Write for prices when ready to order.

\section{FERTILIZERS}

$100 \mathrm{lb}$. Ton

Acid Hhosphate, $16 \%$.......\$2.25 $\$ 36.00$

Bone Meal Fertilizer ........ 4.00

Nitrutc of Soda ............... 6.50

FROST PROOF CABBAGE PLANTS Ready for Shipment Now

Charlesten WakefieId, Jersey Wake. field, Succession and Early Flat Dutch. Pareel Post paid: $100,50 \mathrm{c} ; 500, \$ 2.00$ : $1000, \$ 3.00$.

Express Collect: $100,40 \mathrm{c} ; 500, \$ 1.75$ : $1000, \$ 2.75 ; 5000, \$ 13.50$.

All shipped from Memphis. 


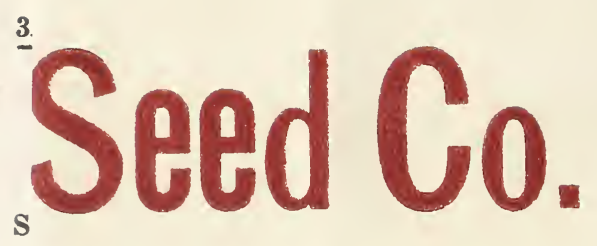

\section{TENN.}

ne to time, we issue a new list every he advantage of any drop. Should

\section{BILL OF LADING ATTACHED}

\section{MILLET}

Catalogue Page No. 25

$\mathrm{Pk}$. Bu.

Tenn. Golden

Western Golden

$1.00 \quad 3.00$

$75 \quad 2.50$
In

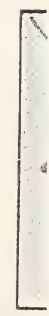

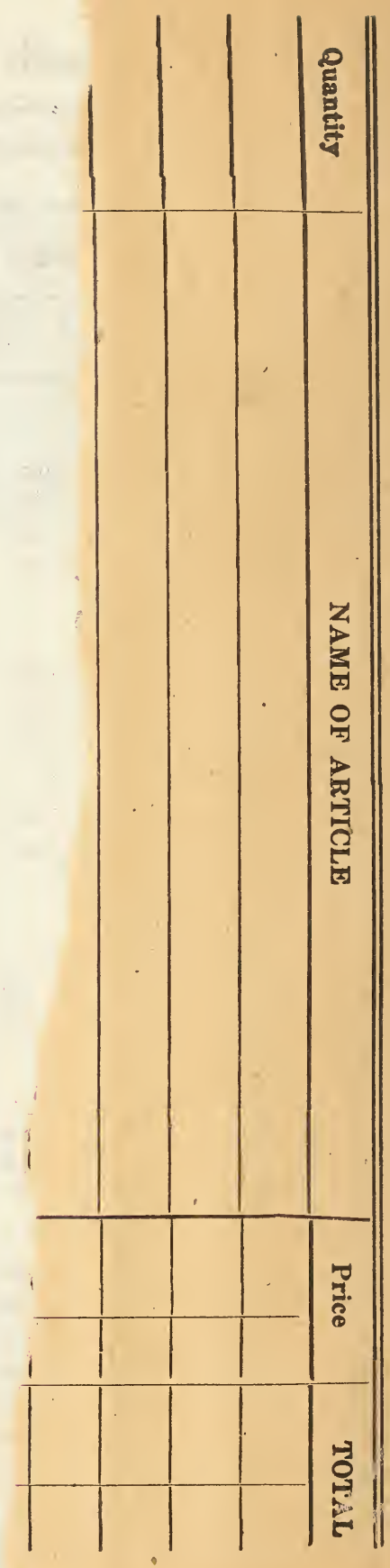




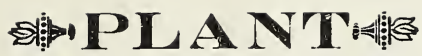 \\ Grafted Pecan Trees}

\section{Direct From the Nursery. \\ Established 1883.}

Good Pecan Trees put permanent and increasing value on Southern Lands. Better than life insurance.

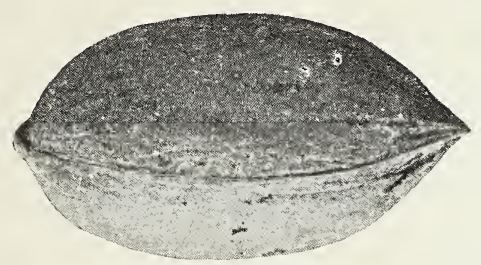

\begin{tabular}{|c|c|c|c|}
\hline & Each & 10 Trees & 100 Trees \\
\hline 6 & feet $\ldots \ldots \ldots \ldots \ldots \ldots$ & $\$ 12.00$ & $\$ 115.00$ \\
\hline 7 & feet .................... 1.75 & 15.00 & 125.00 \\
\hline $7-9$ & feet....................... 2.00 & 17.50 & 150.00 \\
\hline 10 & feet ..................... 350 & 30.00 & 275.00 \\
\hline
\end{tabular}

\section{VARIETIES :}

Success, Stuart, Frotscher, Steckler, Schley, Mexican Papershell.

WRITE FOR PECAN BOOK FREE telling you all about planting, fertilizing and cultivating of Pecan Trees.

No order under $\$ 5$. accepted.

\section{The N. O. PECAN NURSERY CO.}

\section{ST. CHARLES AVENUE,}

NEW ORLEANS, LA. 



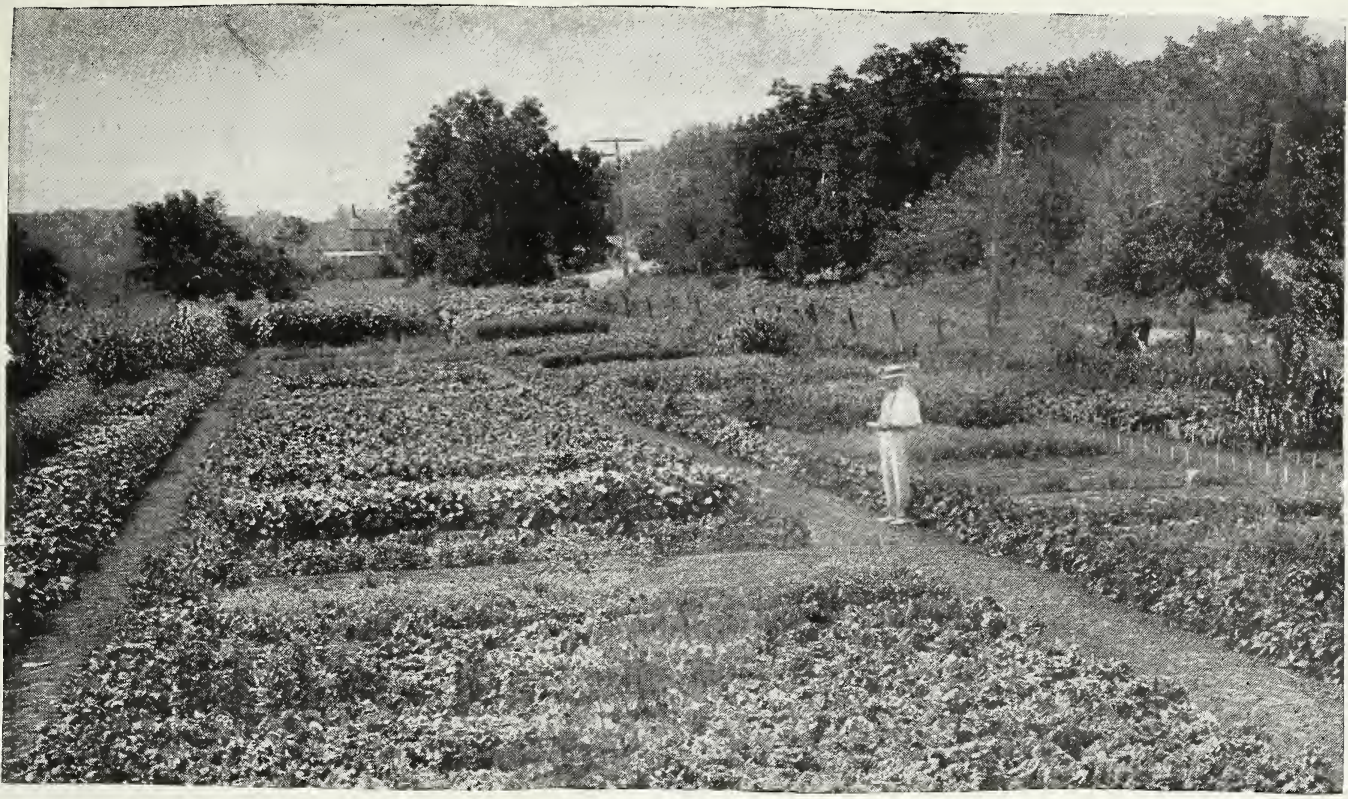

\section{HELPE UL INEORMATION FOR THE FARMER AND GARDENER} When to Plant--How to Plant-When to Harvest

\begin{tabular}{|c|c|c|c|c|c|c|c|c|c|c|c|c|c|c|c|c|c|c|c|}
\hline VEGE & 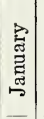 & 旅 & 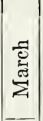 & 莺 & $\stackrel{\Xi}{\mathrm{E}}$ & 莺 & 齐 & 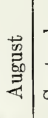 & 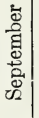 & 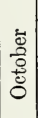 & 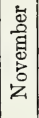 & 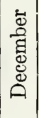 & $\begin{array}{l}\text { Length of } \\
\text { Row an } \\
\text { Ounce of } \\
\text { Seed Will } \\
\text { Plant }\end{array}$ & $\begin{array}{c}\text { No. of } \\
\text { Plants } \\
\text { to } \\
\text { 100 Feet } \\
\text { of Row }\end{array}$ & $\begin{array}{c}\text { No.of } \\
\text { Days } \\
\text { to } \\
\text { Germi- } \\
\text { nate }\end{array}$ & $\begin{array}{l}\text { Dis- } \\
\text { tance } \\
\text { Apart } \\
\text { in } \\
\text { Row }\end{array}$ & $\begin{array}{l}\text { Dis- } \\
\text { tance } \\
\text { of } \\
\text { Rows } \\
\text { Apart }\end{array}$ & $\begin{array}{c}\text { Depth } \\
\text { to } \\
\text { Cover } \\
\text { Seed }\end{array}$ & $\begin{array}{l}\text { Ready for } \\
\text { Use }\end{array}$ \\
\hline & $\ldots$ & & & A & C & C & C & & $\ldots$ & & & & at. & 300 & 10 & 4 in. & $2 \mathrm{ft}$. & 2 in. & \\
\hline & & & & & A & 4 & & & & & & $\ldots$ & & & & $3 \mathrm{ft}$. & $4 \mathrm{ft}$. & & \\
\hline & & & E & E & A & & $\Lambda$ & A & & & $\ldots$ & & & 30 & & & $1 \mathrm{ft}$. & & \\
\hline & $\ldots$ & E & $\mathrm{E}$ & $\mathrm{B}$ & B & B & $\mathrm{H}$ & $\mathrm{H}$ & & & & & & & $6-10$ & 2 & $21 / 2 \mathrm{ft}$. & & $\mathrm{w}$ \\
\hline & & & & & B & & & & & & & & & & & & & $1 / 2 \mathrm{in}$. & \\
\hline & & $\mathrm{E}$ & $\mathrm{E}$ & B & B & B & & & $\mathrm{H}$ & $\mathrm{H}$ & & .... & & 4 & 0 & $21 / 2 \mathrm{ft}$. & 272 & $1 / 2$ & \\
\hline & $\ldots$ & G & G & $\mathrm{F}$ & A & A & A & A & & & 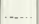 & & & 30 & $10-15$ & 4 in. & $11 / 2 \mathrm{ft}$. & $1 / 2$ in. & \\
\hline & & $\mathrm{E}$ & E & B & $\mathrm{B}$ & $\mathrm{D}$ & & & $\ldots$ & $\ldots$ & & & & 4 & $6-10$ & $2 \mathrm{ft}$. & $21 / 2 \mathrm{ft}$. & & $14-1$ \\
\hline & & E & $\mathrm{E}$ & B & B & B & & & & & ... & $\ldots$. & & 20 & $12-20$ & 6 & $11 / 2 \mathrm{ft}$. & & a \\
\hline & & E & $\mathrm{E}$ & & B & & & & & & & & & 20 & & & $3 \mathrm{ft}$. & $1 / 4 \mathrm{in}$ & $18-2$ \\
\hline & $\ldots$ & & & C & C & C & C & A & & $\ldots$. & & & & 3 & & 3 & $4 \mathrm{ft}$. & $1 \mathrm{in}$. & \\
\hline & 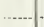 & & & $\mathrm{T}$ & A & , & & & & & & $\ldots .$. & & 2 & $5-10$ & $4 \mathrm{ft}$. & $4 \mathrm{ft}$. & $1 / 2$ in. & \\
\hline & $\ldots$ & G & $\mathrm{E}$ & B & B & B & & & & $\ldots$ & $\ldots$ & $\ldots$ & & 5 & $10-14$ & $2 \mathrm{ft}$. & $21 / 2 \mathrm{ft}$. & $1 / 2$ in. & $18-$ \\
\hline & & & & D & B & B & B & & & & & & & 10 & $6-10$ & $1 \mathrm{ft}$. & $1 \mathrm{ft}$. & & \\
\hline & G & $\mathrm{E}$ & E & $B$ & C & C & C & A & $J$ & $\mathrm{~J}$ & $\mathrm{H}$ & & & & & $1 \mathrm{ft}$. & $11 / 2 \mathrm{ft}$. & $1 / 4 ! n$. & \\
\hline & & & & & & 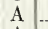 & & & & & & & & & & & & 34 & \\
\hline & $\ldots$ & .... & & $\mathrm{E}$ & A & A & & & $\ldots .$. & $\ldots$ & $\ldots .$. & $\ldots$. & & 1 & $8-12$ & $8 \mathrm{f}$ & $8 \mathrm{ft}$. & $3 \mathrm{in}$. & \\
\hline & ....... & & E & E & $\mathrm{C}$ & C & C & & & & t & $\ldots$. & & 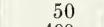 & $15-20$ & $2 \mathrm{f}$ & $3 \mathrm{f}$ & $1 \mathrm{in.}$ & \\
\hline & & $\mathrm{E}$ & $\mathrm{E}$ & $\mathrm{B}$ & B & & & & & & & & & 40 & 8-12 & $3 \mathrm{i}$ & $1 \mathrm{ft}$. & & \\
\hline & & & $F$ & & A & A & & & $\ldots$. & 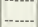 & $\ldots$ & & & & $8-18$ & $6 \mathrm{in}$. & $11 / 2 \mathrm{ft}$. & & \\
\hline & G & G & E & A & A & A & A & A & & $\ldots$ & & & & & $20-24$ & 2 in. & $1 \mathrm{ft}$. & & \\
\hline & 14 & 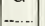 & $\mathrm{F}$ & C & At & C & C & A & 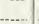 & $\ldots$ & $\ldots$. & $\ldots$ & & 60 & $6-10$ & 2 in. & $2 \mathrm{ft}$. & 2 in. & \\
\hline & 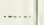 & E & E & $\mathrm{E}$ & B & & & & ..... & $\ldots .$. & ..... & ....... & & 5 & $10-14$ & 2 in & $1 / 2$ in. & $1 / 2 \mathrm{in}$. & $18-$ \\
\hline & & & & $\overline{\mathrm{K}}$ & $K$ & & & & & & & & & & $14-20$ & $1 \mathrm{f}$ & $3 \mathrm{ft}$. & 4 in. & \\
\hline & $\mathrm{M}$ & $\mathrm{M}$ & M & D & D & D & C & C & $\mathrm{J}$ & $\ldots$ & $\ldots$ & & & 1,20 & & & & $1 \frac{1}{2}$ in. & $4-5$ \\
\hline & & & $\mathrm{F}$ & A & & & & A & A & & & & & & $8-12$ & $6 \mathrm{n.}$ & $11 / 2 \mathrm{ft}_{0}$ & $1 / 2 \mathrm{in}$. & $18-20 \mathrm{wk}$ \\
\hline & & & $\mathrm{F}$ & A & A & & . & $\pi$ & $\mathrm{C}$ & $\mathrm{I}$ & & & & & $6-12$ & & $1 \mathrm{ft}$. & $1 / 2 \mathrm{in}$. & . \\
\hline & & & & E & A & A & & & & & $-\cdots$ & & $m$ & $25 \mathrm{hi}$ & $6-10$ & $11 / 2 \mathrm{ft}^{\circ}$ & $3 \mathrm{ft}$. & $1 \mathrm{in}$. & \\
\hline & ..... & & $\mathrm{E}$ & B & B & & & & & & - & & & & 6-10 & $3 \mathrm{ft}$. & $3 \mathrm{ft}$. & $1 / 2 \mathrm{i}$ & $\begin{array}{r}14-1 \\
8-1\end{array}$ \\
\hline Turnips...... & & & & & & & & & & & & & & & & & & & $8-12$ wks \\
\hline
\end{tabular}

\section{KEY TO TABLE}

A-Sow in the open ground. Thin out plants. B-Sow in seed bed in garden and transplant. $\mathrm{C}-$ Make two sowings in open ground for succession. D-Make three sowings in the open ground. E-Startin hotbed and transplant when suitable. $\mathrm{F}-\mathrm{Sc} w$ in the open when ground permits. $\mathrm{G}-$ Grow in hotbed or greenhouses.
$\mathrm{H}$-Sow in cold frame and grow over Winter. Plant out early the following Spring.

I-Sow in open ground and give protection over Winter.

J-Plant in cold frame. Protect with sash.

$\mathrm{K}$-Plant in the open ground.

$\mathrm{M}-$ Sow every week in greenhouse or hotbed.

\section{ILLUSTRATION HOW TO USE TABLE}

Take, for instance, beans, bush. You will find listed aq "A" under April, "C" under May, "C" under June and "C" under July. Refering to key, you will find "A" means sow in the open ground; thin out plants. "C" means make two sowings in open ground for succession. You can, therefore, readily understand that bush beans can be sown in the open groud in April and that two sowings can be made in the open ground during May, June and July. 


\section{Prices}

Owing to the fact that it requires several weeks to have our catalogue printed and shipped to us, we are unable to make prices on many seeds at the time the catalogue was printed, hence it was necessary for us to have prices printed on a separate sheet and inserted at the time of mailing. LOOK FOR YOUR PRICE LIST.

AS TO WARRANTY, We Believe Our Seeds will produce for you the best crops you have ever grown, and to show what confidence we have in our seeds, if they prove otherwise than represented by us, we will refill your order free of charge; but it must be agreed that we do not warrant the crops grown therefrom, either expressed or implied, as to desciption, purity, productiveness or any other matter, and we will not be in any way responsible for them. If the purchaser does not accept our seeds, etc., on these terms they are at once to be returned and the money that has been paid for the same will be refunded. We appreciate your orders and they receive our prompt attention.

By filling and packing great quantities of seed packets of the same kind, we can offer our REGULAR SIZE packets at the following bargains.

The seeds in all of our collections are of the same high quality as those listed elsewhere in this catalogue, and the same liberal packets are used in filling all orders, either for a five-cent order or a $\$ 50.00$ order. ALL FRESH, NEW, TESTED SEEDS. NO CHANGE CAN BE MADE IN ANY COLLECTION, as they are all packed before the busy season.

\section{Ullathorne's Bargain Collections}

\section{Ullathorne's Family Garden} Collection, 50c

This is just the collection for a medium size garden and family. Twelve large packets, regular value, $\$ 1.00$, sent postpaid for $50 \mathrm{c}$.

1 Pkt. BEANS-Red Valentine

1 Pkt. BEETS-Crosby Egyptian

1. Pkt. CABBAGE-Early Wakefield

1 Pkt. SWEET CORN - Stowell's Evergreen

1 Pkt. CUCUMBER-Davis Perfect

1 Pkt. LETTUCE-Wonderful

1 Pkt. PARSNIP - Hollow Crown

1 Pkt. RADISH-French Breakfast

1 Pkt. SPINACH-Curled Savoy

1 Pkt. TURNIP-Purple Top

\section{Ullathorne's Small Garden Collection, 25c}

Eight large packets, regular value $50 \mathrm{c}$, sent postpaid for 25c.

1 Pkt. BEANS-Burpee's Stringless

1 Pkt. BEETS-Crimson Globe

1 Pkt. CARROTS-Danver's Half Long

1 Ykt. CUCUMBER - Early White Spine

1 Pkt. LETTUCE-Hanson Head

1 Pkt. MUSTARD-Curled

1 Pkt. MUSTARD-Giant Curled

1 Pkt. PEAS-Early Alaska

1 Pkt. RADISH-Scarlet Turnip

1 Pkt. TOMATO-Early Detroit

\section{Ullathorne's Flower Garden} Collection, No. 1, 50c

Fourteen packets, regular value $\$ 1.00$, sent postpaid for $50 \mathrm{c}$.

1 Pkt. ASTERS-Superb Mixed

i pkt. BALSAM-Mixed

1 Pkt. CANDYTUFT-Mixed

1 Pkt. CARNATION-Mixed

1 Pkt. CHINA PINK-Double Mixed

1 Pkt. COSMOS-Mixed

1 Pkt. CYPRESS VINE-Mixed

1 Pkt. FOUR O'CLOCK-Mixed

1 Pkt. JAPAN PINK-Mixed

1 Pkt. LARKSPUR-Dwarf Rocket

1 Pkt. PANSIES-Best Mixed

1 Pkt. PHLOX-Mixed

1 Pkt. POPPIES-Mixed

1 Pkt. PETUNIAS-Mixed Colors.

\section{Ullathorne's Large Family Gar-} den Collection, $\$ 1.00$.

This collection will plant a large garden and provide an abundant supply of fresh vegetables for a large family. Fifteen varieties, regular value, $\$ 2.00$, sent postpaid for $\$ 1.00$.

$1 / 4-1 b$. BEANS-Red Valentine

$1 / 4-1 b$. BEANS-Crosby Egyptian

1 Pkt. SWISS CHARD

1 Pkt. CABBAGE-Charleston Wakefield

1 Pkt. CARROT-Long Orange

1 Pkt. CUCUMBER-Davis Perfect.

$1 / 4$-1b. SWEET CORN-Golden Bantam

1 Pkt. LETTUCE-Big Boston

1 Pkt. MUSTARD-Giant Curled

1 Pkt. PARSNIP-Hollow Crown

$1 / 4$-1b. PEAS-Early Alaska

1 Oz. RADISH-White Tipped

1 Pkt. SPINACH-Curled Savoy

1 Pkt. TOMATO-Early Detroit

1 Pkt. TURNIP-Purple Top

\section{Ullathorne's Flower Garden} Collection, No. 2, 25c

Seven large packets, regular value $60 \mathrm{c}$, sent postpaid for 25c.

1 Pkt. BALSAM-Mixed

1 Pkt. COSMOS-Mixed

1 Pkt. CARNATION-Mixed

1 Pkt. PETUNIA-Mixed Colors

1 Pkt. MARIGOLD-Mixed

1 Pkt. POPPIES-Mixed

1 Pkt. ZINNIA-Mixed

\section{Ullathorne's Summer Flower- ing Bulb Collection, No. 3, $\$ 1.00$}

A collection of summer flowering bulbs, easy to grow and sure to bloom the first season. 21 large flowering bulbs sent postpaid for $\$ 1.00$.

6 GLADIOLUS-Best Mixed

3 DAHIIAS-Double Mixed

6 CANNAS-Mixed

6 TUBEROSES-Excelsior Pearl 